\title{
meso-Oxoisocorroles: Tunable Antiaromaticity by Metalation and Coordination of Lewis Acids as well as Aromaticity Reversal in the Triplet Excited State
}

\author{
Kento Ueta, ${ }^{\dagger}$ Jinseok Kim,${ }^{\ddagger}$ Shota Ooi,${ }^{\dagger}$ Juwon Oh,,${ }^{\natural}$ Juhyang Shin, ${ }^{\S}$ Akito Nakai, ${ }^{\dagger}$ \\ Manho Lim, ${ }^{* \S}$ Takayuki Tanaka, ${ }^{* \dagger}$ Dongho Kim, ${ }^{*}: *$ and Atsuhiro Osuka ${ }^{* \dagger}$ \\ 'Department of Chemistry, Graduate School of Science, Kyoto University, Sakyo-ku, Kyoto 606-8502, \\ Japan \\ ${ }^{\ddagger}$ Spectroscopy Laboratory for Functional $\pi$-Electronic Systems and Department of Chemistry, Yonsei \\ University, Seoul 03722, Korea \\ ${ }^{\S}$ Department of Chemistry and Chemistry Institute for Functional Materials, Pusan National University, \\ Busan 46241, Korea \\ ${ }^{\complement}$ Department of Chemistry, Soonchunhyang University, Asan-si 31538, Korea
}

\section{Table of Contents}

1. Experimental Procedures

2. NMR Spectra

3. Mass Spectra

4. UV/Vis Absorption Spectra

5. X-Ray Crystallographic Details

6. Cyclic voltammetry

7. DFT Calculations

8. IR Spectra

9. Excited State Dynamics

10. Supporting References 


\section{General information}

Commercially available solvents and reagents were used without further purification, unless otherwise noted. The spectroscopic grade solvents were used for all the spectroscopic studies. Silica gel column chromatography was performed on Wakogel C300. UV/Vis absorption spectra were recorded on a Shimadzu UV-3600 spectrometer. ${ }^{1} \mathrm{H}$ and ${ }^{19} \mathrm{~F}$ NMR spectra were recorded on a JEOL ECA-600 spectrometer (operating as 600.17 MHz for ${ }^{1} \mathrm{H}, 150.91 \mathrm{MHz}$ for ${ }^{13} \mathrm{C}$, and $564.73 \mathrm{MHz}$ for ${ }^{19} \mathrm{~F}$ ) using the residual solvent as the internal reference for ${ }^{1} \mathrm{H},\left(\delta=7.26 \mathrm{ppm}\right.$ in $\mathrm{CDCl}_{3}, \delta=7.16 \mathrm{ppm}$ in benzene- $d_{6}$, and $\delta=2.08 \mathrm{ppm}$ in toluene- $\left.d_{8}\right),{ }^{13} \mathrm{C}\left(\delta=77.16 \mathrm{ppm}\right.$ in $\mathrm{CDCl}_{3}$ and $\delta=20.43$ ppm in toluene- $\left.d_{8}\right)$ and hexafluorobenzene as an external reference for ${ }^{19} \mathrm{~F}(\delta=-162.9$ ppm). High-resolution atmospheric-pressure-chemical-ionization time-of-flight massspectrometry (HR-APCI-TOF-MS) was recorded on a BRUKER micrOTOF model using positive ion mode. Redox potentials were measured by cyclic voltammetry on an ALS electrochemical analyzer model 612E. Single-crystal X-ray diffraction analysis data were collected at $-180{ }^{\circ} \mathrm{C}$ with a Rigaku XtaLAB P200 by using graphite monochromated $\mathrm{Cu}-K \alpha$ radiation $(\lambda=1.54187 \AA)$. Infrared (IR) spectra were recorded on a Thermo Scientific Nicolet iS5 spectrometer. The structures were solved by direct methods (SHELXT-2014/5) $)^{[\mathrm{S} 1, \mathrm{~S} 2]}$ and refined with full-matrix least-square technique (SHELXL-2014/7). ${ }^{[\mathrm{S} 3]}$ All calculations were carried out using the Gaussian 16 program. [S4]

\section{Femtosecond Transient Absorption Measurements.}

The femtosecond transient absorption spectra were measured with pump-probe spectrometer, whichis consisted of Optical Parametric Amplifiers (Palitra, Quantronix) pumped by a Ti:sapphire regenerative amplifier system (Integra-C, Quantronix) operating at $1 \mathrm{kHz}$ repetition rate and an optical detection system. The generated OPA pulses had a pulse width of $\sim 100 \mathrm{fs}$ and an average power of $100 \mathrm{~mW}$ in the range 280 $2700 \mathrm{~nm}$ which were used as pump pulses. White light continuum (WLC) probe pulses were generated using a sapphire window ( $3 \mathrm{~mm}$ of thickness) by focusing of small portion of the fundamental $800 \mathrm{~nm}$ pulses which was picked off by a quartz plate before entering to the OPA. ${ }^{[\mathrm{S} 5]}$ 
After the measurements, we carefully checked absorption spectra of all compounds to detect if there were artifacts due to degradation and photo-oxidation of samples. HPLC grade solvents were used in all measurements. The three-dimensional data sets of $\Delta \mathrm{A}$ versus time and wavelength were subjected to singular value decomposition and global fitting to obtain the kinetic time constants and their associated spectra using Surface Xplorer software (Ultrafast Systems).

\section{The femtosecond time-resolved IR spectroscopy.}

For measurement of femtosecond time-resolved IR spectra, a mid-IR probe pulse was generated by a home-built OPA, pumped by a Ti:sapphire amplified pulse. A small portion of the fundamental pulse was frequency doubled to produce a pump pulse at 400 nm with $1 \mu \mathrm{J}$ of energy. The OPA was used to generate a tunable mid-IR probe pulse by difference frequency mixing of its signal and idler pulses. The probe pulse was sent through the sample for the time-resolved mid-IR absorbance after the optically delayed pump pulse irradiated the sample. The broadband-transmitted probe pulse was detected by a 128 -element $\mathrm{N}_{2}(1)$-cooled $\mathrm{HgCdTe}$ array detector that was mounted on the focal plane of a $320 \mathrm{~mm}$ IR monochromator with a $150 \mathrm{l} / \mathrm{mm}$ grating. The spectral resolution of this configuration resulted in about $0.87 \mathrm{~cm}^{-1} /$ pixel at $1490 \mathrm{~cm}^{-1}$. Spectra spanning about $400 \mathrm{~cm}^{-1}$ were superposition of five 128-point spectra that overlapped by several elements. The instrument response function was typically $160 \mathrm{fs}$. The time-resolved IR spectra were obtained under flowing condition. ${ }^{[\mathrm{S} 6, \mathrm{~S} 7]}$ 


\section{Experimental procedure}

\section{5,15-Bis(pentafluorophenyl)corrole (1)}

DDQ (0.72 g, $3.2 \mathrm{mmol}, 2.2$ eq.) was added to dichloromethane solution (3 L) of 5,15-bis(pentafluorophenyl)tetrapyrrane $(0.95 \mathrm{~g}, 1.5 \mathrm{mmol})$, and the solution was stirred for 10 minutes at room temperature. Then, the solution was passed through a short silica-gel pad and then evaporated. The crude mixture was purified by silica gel column chromatography using $n$-hexane/dichloromethane $(v / v=7 / 3)$ as an eluent. Then, recrystallization from dichloromethane/n-hexane afforded 5,15-bis(pentafluorophenyl)corrole 1 as purple solids (0.39 g, 41\%, averaged for 4 runs); The optical properties were consistent with the previous report. ${ }^{[88]}$

\section{0-Oxo-5,15-bis(pentafluorophenyl)isocorrole (4)}

Corrole 1 (200 mg, $0.32 \mathrm{mmol}$ ) was dissolved in dichloromethane (200 mL), and the solution was passed through a short pad of $\mathrm{MnO}_{2}$ on Celite ${ }^{\circledast}$. The crude mixture was purified with silica gel column chromatography using $n$ hexane/dichloromethane $(v / v=1 / 1)$ as an eluent. Then, recrystallization from dichloromethane/n-hexane afforded 10-oxo-5,15-bis(pentafluorophenyl)corrole 4 as brown solids (146 $\mathrm{mg}, 71 \%$ )

${ }^{1} \mathrm{H}$ NMR $\left(600 \mathrm{MHz}, \mathrm{CDCl}_{3}, 25^{\circ} \mathrm{C}\right) \delta / \mathrm{ppm}=20.51(\mathrm{~s}, 2 \mathrm{H}, \mathrm{NH}), 6.63(\mathrm{~d}, J=4.8 \mathrm{~Hz}$, $2 \mathrm{H}), 6.09(\mathrm{~d}, J=4.8 \mathrm{~Hz}, 2 \mathrm{H}, \beta-\mathrm{H}), 6.04(\mathrm{~d}, J=4.1 \mathrm{~Hz}, 2 \mathrm{H}, \beta-\mathrm{H}), 5.92(\mathrm{~d}, J=4.1 \mathrm{~Hz}$, $2 \mathrm{H}, \beta-\mathrm{H}) ;{ }^{13} \mathrm{C} \mathrm{NMR}\left(151 \mathrm{MHz}, \mathrm{CDCl}_{3}, 25^{\circ} \mathrm{C}\right) \delta / \mathrm{ppm}=151.8,151.2,145.9,144.1$, $129.5,126.2,122.2,119.2$, some peaks were not observed due to broadening stemmed from C-F coupling; ${ }^{19} \mathrm{~F}$ NMR $\left(565 \mathrm{MHz}, \mathrm{CDCl}_{3}, 25^{\circ} \mathrm{C}\right) \delta / \mathrm{ppm}=-137.1$ $(\mathrm{d}, J=17.5 \mathrm{~Hz}, 4 \mathrm{~F}, o-\mathrm{F}),-150.6(\mathrm{t}, J=17.5 \mathrm{~Hz}, 2 \mathrm{~F}, p-\mathrm{F}),-159.6(\mathrm{t}, J=17.5 \mathrm{~Hz}, 4 \mathrm{~F}$, $m$-F). $m / z=644.0686$ (calcd. for $\left[\mathrm{C}_{31} \mathrm{H}_{10} \mathrm{~N}_{4} \mathrm{OF}_{10}\right]^{+} ;[\mathrm{M}]^{+}, \mathrm{m} / \mathrm{z}=644.0689$ ); FTIR(ATR) wavenumber $/ \mathrm{cm}^{-1}=2924.21,2854.24,1652.03,1609.55,1574.87$, 1547.91, 1523.14, 1506.86, 1482.04, 1429.20, 1364.64, 1320.81, 1295.36, 1280.59, $1258.47,1232.58,1218.96,1189.17,1169.92,1150.57,1106.46,1074.78,1059.80$, 1037.19, 1007.52, 981.29, 964.96, 941.67, 924.74, 837.21, 807.92, 785.86, 767.21, $756.59,698.81$. 


\section{0-Oxo-5,15-bis(pentafluorophenyl)isocorrole nickel(II) complex (4Ni)}

Oxoisocorrole 4 (32 mg, $50 \mu \mathrm{mol})$ and $\mathrm{Ni}(\mathrm{acac}) 2(64 \mathrm{mg}, 0.25 \mathrm{mmol}, 5$ eq.) were dissolved in toluene $(3 \mathrm{~mL})$ and the solution was refluxed at $120^{\circ} \mathrm{C}$ for $1.5 \mathrm{~h}$. The solution was cooled down to room temperature and passed through a short pad of silica gel. After evaporation, recrystallization from dichloromethane $/ n$-hexane afforded nickel complex $4 \mathrm{Ni}$ as green solids ( $33 \mathrm{mg}, 94 \%$ )

${ }^{1} \mathrm{H}$ NMR $\left(600 \mathrm{MHz}, \mathrm{CDCl}_{3}, 25^{\circ} \mathrm{C}\right) \delta / \mathrm{ppm}=5.54(\mathrm{~d}, J=4.6 \mathrm{~Hz}, 2 \mathrm{H}, \beta-\mathrm{H}), 4.85(\mathrm{~d}, J$ $=4.6 \mathrm{~Hz}, 2 \mathrm{H}, \beta-\mathrm{H}), 4.79(\mathrm{~d}, J=4.6 \mathrm{~Hz}, 2 \mathrm{H}, \beta-\mathrm{H}), 4.75(\mathrm{~d}, J=4.6 \mathrm{~Hz}, 2 \mathrm{H}, \beta-\mathrm{H}) ;{ }^{13} \mathrm{C}$ NMR $\left(151 \mathrm{MHz}, \mathrm{CDCl}_{3}, 25^{\circ} \mathrm{C}\right) \delta / \mathrm{ppm}=174.1,163.7,152.4,144.7,142.4,135.3$, $131.7,130.8,121.0,118.0$, some peaks were not observed due to broadening stemmed from C-F coupling; ${ }^{19} \mathrm{~F}$ NMR $\left(565 \mathrm{MHz}, \mathrm{CDCl}_{3}, 25^{\circ} \mathrm{C}\right) \delta / \mathrm{ppm}=-137.7$ $(\mathrm{d}, J=17.5 \mathrm{~Hz}, 4 \mathrm{~F}),-150.8(\mathrm{t}, J=17.5 \mathrm{~Hz}, 2 \mathrm{~F}),-159.3(\mathrm{~d}, J=17.5 \mathrm{~Hz}, 4 \mathrm{~F}) ; \mathrm{m} / z=$ 699.9875 (calcd. for $\left[\mathrm{C}_{31} \mathrm{H}_{8} \mathrm{~N}_{4} \mathrm{OF}_{10}{ }^{58} \mathrm{Ni}\right]^{+} ;[M]^{+}, m / z=699.9886$ ); FT-IR(ATR) wavenumber $/ \mathrm{cm}^{-1}=2923.13,2853.31,1668.61,1652.21,1635.34,1607.38$, $1558.28,1513.82,1486.24,1366.83,1298.34,1258.29,1234.09,1220.72,1191.31$, $1053.42,1019.89,980.24,925.64,852.38,837.44,808.99,802.72,761.41$.

\section{0-Oxo-5,15-bis(pentafluorophenyl)isocorrole palladium(II) complex (4Pd)}

Oxoisocorrole 4 (16 mg, $25 \mu \mathrm{mol})$ and $\mathrm{PdCl}_{2}$.(PhCN) $2(29 \mathrm{mg}, 75 \mu \mathrm{mol}, 3$ eq.) were dissolved in benzonitrile $(0.75 \mathrm{~mL})$ and the solution was refluxed at $170{ }^{\circ} \mathrm{C}$ for 1 $\mathrm{h}$. The solution was cooled down to room temperature and passed through a short pad of silica gel. After evaporation, recrystallization from dichloromethane/n-hexane afforded palladium complex $4 \mathbf{P d}$ as yellow-green solids (16.3 mg, $87 \%)$.

${ }^{1} \mathrm{H}$ NMR $\left(600 \mathrm{MHz}, \mathrm{CDCl}_{3}, 25^{\circ} \mathrm{C}\right) \delta / \mathrm{ppm}=5.80(\mathrm{~d}, J=4.6 \mathrm{~Hz}, 2 \mathrm{H}, \beta-\mathrm{H}), 5.16(\mathrm{~d}, J$ $=4.6 \mathrm{~Hz}, 2 \mathrm{H}, \beta-\mathrm{H}), 5.15(\mathrm{~d}, J=4.6 \mathrm{~Hz}, 2 \mathrm{H}, \beta-\mathrm{H}), 5.09(\mathrm{~d}, J=4.6 \mathrm{~Hz}, 2 \mathrm{H}, \beta-\mathrm{H}) ;{ }^{13} \mathrm{C}$ $\operatorname{NMR}\left(151 \mathrm{MHz}, \mathrm{CDCl}_{3}, 25^{\circ} \mathrm{C}\right) \delta / \mathrm{ppm}=176.3,161.2,150.9,141.2,139.8,137.2$, $130.5,129.9,120.3,119.0$, some peaks were not observed due to broadening stemmed from C-F coupling; ${ }^{19} \mathrm{~F}$ NMR $\left(565 \mathrm{MHz}, \mathrm{CDCl}_{3}, 25^{\circ} \mathrm{C}\right) \delta / \mathrm{ppm}=-137.5$ $(\mathrm{d}, J=17.5 \mathrm{~Hz}, 4 \mathrm{~F}, o-\mathrm{F}),-150.7(\mathrm{t}, J=17.5 \mathrm{~Hz}, 2 \mathrm{~F}, p-\mathrm{F}),-159.3(\mathrm{t}, J=17.5 \mathrm{~Hz}, 4 \mathrm{~F}$, $m-\mathrm{F}) ; m / z=745.9510$ (calcd. for $\left.\left[\mathrm{C}_{31} \mathrm{H}_{8} \mathrm{~N}_{4} \mathrm{OF}_{10}{ }^{104} \mathrm{Pd}\right]^{+} ;[M]^{+}, m / z=745.9574\right)$; FTIR(ATR) wavenumber $/ \mathrm{cm}^{-1}=2922.75,2853.04,1732.73,1715.37,1652.70$, 
$1607.99,1508.10,1488.68,1463.09,1374.36,1463.09,1374.36,1359.03,1309.83$, $1256.31,1249.29,1166.63,1047.18,1021.28,1000.35,977.61,942.42,847.76,764.66$, $756.98,740.42,727.83,701.33$.

\section{0-Oxo-5,15-bis(pentafluorophenyl)isocorrole zinc(II) complex (4Zn)}

Oxoisocorrole 4 (16 mg, $25 \mu \mathrm{mol}$ ) and $\mathrm{Zn}(\mathrm{OAc}) 2(22 \mathrm{mg}, 125 \mu \mathrm{mol}, 5$ eq.) were dissolved in dichloromethane/methanol $(4 \mathrm{~mL} / 1 \mathrm{~mL})$ and the solution was stirred at $40{ }^{\circ} \mathrm{C}$ for $1 \mathrm{~h}$. The solution was passed through a short pad of silica gel. After evaporation, recrystallization from dichloromethane $/ n$-hexane afforded zinc complex $4 \mathrm{Zn}$ as brown solids ( $15 \mathrm{mg}$, $85 \%$ )

$\left(600 \mathrm{MHz}, \mathrm{THF}-d_{8}, 25^{\circ} \mathrm{C}\right) \delta / \mathrm{ppm}=6.20(\mathrm{~d}, J=4.1 \mathrm{~Hz}, 2 \mathrm{H}, \beta-\mathrm{H}), 6.03(\mathrm{~d}, J=4.1 \mathrm{~Hz}$, $2 \mathrm{H}, \beta-\mathrm{H}), 5.94(\mathrm{~d}, J=4.1 \mathrm{~Hz}, 2 \mathrm{H}, \beta-\mathrm{H}), 5.73(\mathrm{~d}, J=4.1 \mathrm{~Hz}, 2 \mathrm{H}, \beta-\mathrm{H}) ;{ }^{19} \mathrm{~F}-\mathrm{NMR}(565$ MHz, THF- $\left.d s, 25^{\circ} \mathrm{C}\right) \delta / \mathrm{ppm}=-141.0(\mathrm{~d}, J=17.5 \mathrm{~Hz}, 4 \mathrm{~F}, o-\mathrm{F}),-155.7(\mathrm{t}, J=21.9 \mathrm{~Hz}$, $2 \mathrm{~F}, p-\mathrm{F}),-163.2(\mathrm{t}, J=21.9 \mathrm{~Hz}, 4 \mathrm{~F}, m-\mathrm{F}) ; m / z=705.9817$ (calcd. for $\left.\left[\mathrm{C}_{31} \mathrm{H}_{8} \mathrm{~N}_{4} \mathrm{OFF}_{10}{ }^{64} \mathrm{Zn}\right]^{+} ;[M]^{+}, \mathrm{m} / \mathrm{z}=705.9824\right) ; \mathrm{FT}-\mathrm{IR}(\mathrm{ATR})$ wavenumber $/ \mathrm{cm}^{-1}=$ 2923.43, 2853.32, 1652.70, 1636.30, 1508.06, 1487.32, 1467.23, 1436.67, 1367.21, 1354.64, 1265.11, 1239.32, 1265.11, 1239.32, 1186.07, 1051.84, 1020.97, 987.10, $848.65,765.09$.

10-Oxo-5,15-bis(pentafluorophenyl)isocorrole pyridinated zinc(II) complex (4ZnPy)

Oxoisocorrole 4 (16 mg, $25 \mu \mathrm{mol}$ ) and $\mathrm{Zn}(\mathrm{OAc})_{2}(22 \mathrm{mg}, 125 \mu \mathrm{mol}, 5$ eq.) were dissolved in dichloromethane/methanol $(4 \mathrm{~mL} / 1 \mathrm{~mL})$ and the solution was stirred at $40{ }^{\circ} \mathrm{C}$ for $1 \mathrm{~h}$. The solution was passed through a short pad of silica gel. After evaporation, recrystallization from dichloromethane/pyridine/ $n$-hexane afforded pyridinated zinc complex $4 \mathrm{ZnPy}$ as brown solids $(17 \mathrm{mg}, 86 \%)$ ${ }^{1} \mathrm{H}$ NMR $\left(600 \mathrm{MHz}, \mathrm{CDCl}_{3}, 25^{\circ} \mathrm{C}\right) \delta / \mathrm{ppm}=10.17$ (brs, $\left.2 \mathrm{H}, \mathrm{Py}-\alpha-\mathrm{H}\right), 8.33$ (brs, $1 \mathrm{H}$, Py- $\gamma-\mathrm{H}), 8.02$ (brs, 2H, Py- $\beta-\mathrm{H}), 6.29(\mathrm{~d}, J=4.1 \mathrm{~Hz}, 2 \mathrm{H}, \beta-\mathrm{H}), 5.88(\mathrm{~d}, J=4.1 \mathrm{~Hz}$, $2 \mathrm{H}, \beta-\mathrm{H}), 5.83(\mathrm{~d}, J=4.1 \mathrm{~Hz}, 2 \mathrm{H}, \beta-\mathrm{H}), 5.63(\mathrm{~d}, J=4.1 \mathrm{~Hz}, 2 \mathrm{H}, \beta-\mathrm{H}) ;{ }^{13} \mathrm{C}-\mathrm{NMR}(151$ $\left.\mathrm{MHz}, \mathrm{CDCl}_{3}, 25^{\circ} \mathrm{C}\right) \delta / \mathrm{ppm}=177.0,158.5,156.4,150.1,145.5,145.0,140.5,133.8$, $133.1,127.5,126.9,119.5,119.5,111.0$, some peaks were not observed due to broadening stemmed from C-F coupling; ${ }^{19} \mathrm{~F}-\mathrm{NMR}\left(565 \mathrm{MHz}, \mathrm{CDCl}_{3}, 25{ }^{\circ} \mathrm{C}\right.$ ) 
$\delta / \mathrm{ppm}=-137.6(\mathrm{brs}, 2 \mathrm{~F}, o-\mathrm{F}),-139.3(\mathrm{brs}, 2 \mathrm{~F}, o-\mathrm{F}),-152.1(\mathrm{t}, J=21.9 \mathrm{~Hz}, 2 \mathrm{~F}, p-\mathrm{F}),-$ 160.0 (brs, 2F, m-F), -160.5 (brs, 2F, m-F). F); $m / z=706.9903$ (calcd. for $\left.\left[\mathrm{C}_{31} \mathrm{H}_{9} \mathrm{~N}_{4} \mathrm{OFF}_{10}{ }^{64} \mathrm{Zn}\right]^{+} ;[\mathrm{M}+\mathrm{H} \text {-pyridine }]^{+}, \mathrm{m} / z=706.9903\right)$; FT-IR(ATR) wavenumber $/ \mathrm{cm}^{-1}=2920.36,2850.76,1652.38,1610.88,1543.61,1488.05,1446.29,1369.23$, 1348.85, 1298.70, 1266.66, 1251.23, 1238.02, 1216.00, 1183.12, 1054.06, 1043.47, 1014.72, 985.38, 962.56, 888.13, 847.47, 801.32, 754.03, 741.98, 692.06, 664.86, 636.71, 617.60 .

10-Oxo-5,15-bis(pentafluorophenyl)isocorrolato

nickel(II)

\section{tris(pentafluorophenyl)borane complex $\left(4 \mathrm{Ni} \cdot \mathrm{B}\left(\mathrm{C}_{6} \mathrm{~F}_{5}\right)_{3}\right)$}

${ }^{1} \mathrm{H}$ NMR $\left(600 \mathrm{MHz}\right.$, benzene- $\left.d_{6}, 25^{\circ} \mathrm{C}\right) \delta / \mathrm{ppm}=4.40(\mathrm{brs}, 2 \mathrm{H}, \beta-\mathrm{H}), 3.00$ (brs, $4 \mathrm{H}$, $\beta-\mathrm{H}), 2.84$ (brs, $2 \mathrm{H}, \beta-\mathrm{H})$,

$\left(600 \mathrm{MHz}\right.$, toluene- $\left.d_{8}, 25^{\circ} \mathrm{C}\right) \delta / \mathrm{ppm}=4.33(\mathrm{brs}, 2 \mathrm{H}, \beta-\mathrm{H}), 3.00(\mathrm{brs}, 4 \mathrm{H}, \beta-\mathrm{H}), 2.86$ (brs, $2 \mathrm{H}, \beta-\mathrm{H})$;

$\left(600 \mathrm{MHz}\right.$, toluene- $\left.d_{8},-60{ }^{\circ} \mathrm{C}\right) \delta / \mathrm{ppm}=3.61(\mathrm{brs}, 1 \mathrm{H}, \beta-\mathrm{H}), 3.44(\mathrm{brs}, 1 \mathrm{H}, \beta-\mathrm{H}), 3.29$ $(\mathrm{d}, J=4.2 \mathrm{~Hz}, 1 \mathrm{H}, \beta-\mathrm{H}), 3.24$ (brs, $1 \mathrm{H}, \beta-\mathrm{H}), 1.46$ (d, $J=4.2 \mathrm{~Hz}, 1 \mathrm{H}, \beta-\mathrm{H}), 1.36$ (d, J $=3.7 \mathrm{~Hz}, 1 \mathrm{H}, \beta-\mathrm{H}), 1.25(\mathrm{~d}, J=4.6 \mathrm{~Hz}, 2 \mathrm{H}, \beta-\mathrm{H})$, *note: peak stemmed from $\left(\mathrm{C}_{6} \mathrm{~F}_{5}\right)_{3} \mathrm{~B}-\mathrm{O} \underline{\mathrm{H}}_{2}$ was observed at $4.66 \mathrm{ppm}$;

$\left(600 \mathrm{MHz}\right.$, toluene- $\left.d_{8},-80^{\circ} \mathrm{C}\right) \delta / \mathrm{ppm}=3.56(\mathrm{brs}, 2 \mathrm{H}, \beta-\mathrm{H}), 3.38(\mathrm{~m}, 4 \mathrm{H}, \beta-\mathrm{H}), 3.18$ (brs, 2H, $\beta-\mathrm{H}$ ), 1.49 (brs 2H, $\beta-\mathrm{H}), 1.43$ (brs, 2H, $\beta-\mathrm{H}), 1.28$ (brs, $4 \mathrm{H}, \beta-\mathrm{H})$, *note: peak stemmed from $\left(\mathrm{C}_{6} \mathrm{~F}_{5}\right)_{3} \mathrm{~B}-\mathrm{OH}_{2}$ was observed at $4.63 \mathrm{ppm}$. Spectra measured at $0,-20$, and $-40^{\circ} \mathrm{C}$ were omitted due to their signal broadening.

${ }^{13} \mathrm{C}-\mathrm{NMR}\left(151 \mathrm{MHz}\right.$, toluene- $\left.d_{8}, 25{ }^{\circ} \mathrm{C}\right) \delta / \mathrm{ppm}=149.0,147.4,138.5,136.9$, 117.8 . some peaks were not observed due to broadening stemmed from C-F coupling; ${ }^{19} \mathrm{~F}-\mathrm{NMR}\left(565 \mathrm{MHz}\right.$, benzene- $\left.d_{6}, 25^{\circ} \mathrm{C}\right) \delta / \mathrm{ppm}=-134.1$ (brs, 6F, o-F of BAr 3 ), 138.5 (brs, 4F, o-F of meso-Ar), -150.4 (brs, 4F, p-F of meso-Ar), -154.3 (brs, 3F, p-F of $\left.\mathrm{BAr}_{3}\right),-158.6$ (brs, 4F, m-F of meso-Ar), -162.6 (brs, 6F, $m$-F of BAr3);

$\left(565 \mathrm{MHz}\right.$, toluene- $\left.d_{8}, 25{ }^{\circ} \mathrm{C}\right) \delta / \mathrm{ppm}=-134.2(\mathrm{brs}, 4 \mathrm{~F}, o-\mathrm{F}$ of BAr 3$),-138.6(\mathrm{~d}, J=$ 17.6 Hz, 2F, o-F of meso-Ar), $-150.4(\mathrm{t}, J=17.6 \mathrm{~Hz}, 2 \mathrm{~F}, p$-F of meso-Ar), -154.2 (brs, $2 \mathrm{~F}, p-\mathrm{F}$ of $\mathrm{BAr} 3),-158.6$ (brs, 2F, $m$-F of meso-Ar), -162.5 (brs, 2F, $m-\mathrm{F}$ of BAr 3 ); $\left(565 \mathrm{MHz}\right.$, toluene- $\left.d_{8},-40{ }^{\circ} \mathrm{C}\right) \delta / \mathrm{ppm}=-134.6(\mathrm{~d}, J=17.5 \mathrm{~Hz}, 6 \mathrm{~F}, o-\mathrm{F}$ of BAr 3 ), 137.6 (brs, 2F, o-F of meso-Ar), -138.6 (brs, 2F, o-F of meso-Ar), -149.5 (brs, $1 \mathrm{~F}, p-\mathrm{F}$ 
of meso-Ar), -149.8 (brs, 1F, $p$-F of meso-Ar), -154.0 (brs, 3F, p-F of BArs), -157.4 (brs, 2F, m-F of meso-Ar), -158.4 (brs, 2F, m-F of meso-Ar), -162.2 (brs, $6 \mathrm{~F}, m-\mathrm{F}$ of $\mathrm{BAr} 3)$. Spectra measured at $0,-20,-60$, and $-80^{\circ} \mathrm{C}$ were omitted due to their signal broadening.

FT-IR(ATR) wavenumber $/ \mathrm{cm}^{-1}=3196.65,1651.54,1558.59,1519.63,1488.74$, 1462.76, 1369.94, 1339.80, 1312.80, 1260.84, 1197.44, 1099.64, 1054.27, 1024.04, $963.79,851.91,806.95,762.10,707.03,673.53,622.72$. 


\section{NMR spectra}

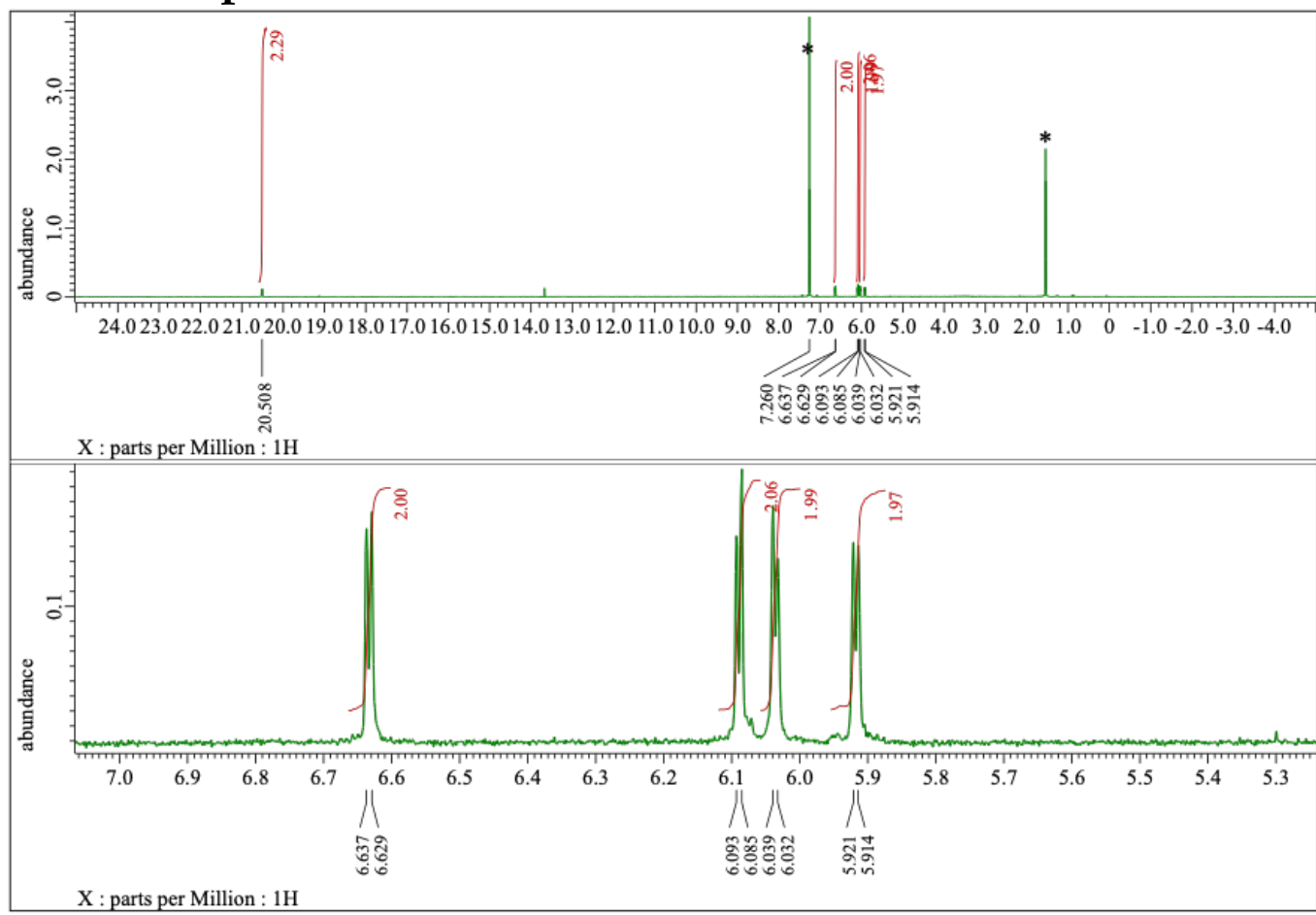

Figure S2-1. ${ }^{1} \mathrm{H}$ NMR spectrum of 4 in $\mathrm{CDCl}_{3}$ at $25{ }^{\circ} \mathrm{C} .{ }^{*}$ indicates residual solvents and impurities.



Figure S2-2. ${ }^{13} \mathrm{C}$ NMR spectrum of 4 in $\mathrm{CDCl}_{3}$ at $25^{\circ} \mathrm{C}$. ${ }^{*}$ indicates residual solvents and impurities. 


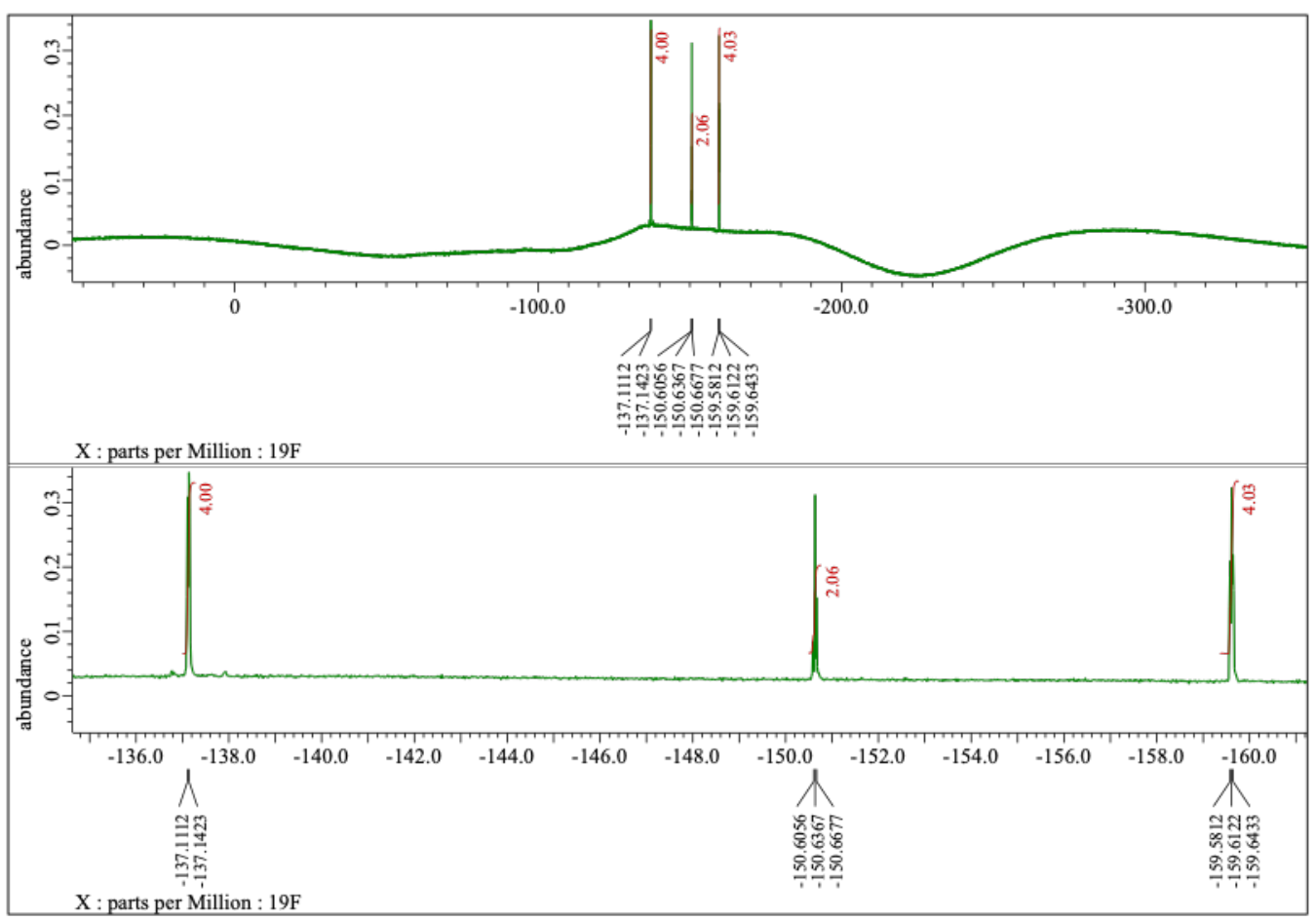

Figure S2-3. ${ }^{19} \mathrm{~F}$ NMR spectrum of 4 in $\mathrm{CDCl}_{3}$ at $25^{\circ} \mathrm{C}$.



Figure S2-4. ${ }^{1} \mathrm{H}$ NMR spectrum of $4 \mathrm{Ni}$ in $\mathrm{CDCl}_{3}$ at $25{ }^{\circ} \mathrm{C} .{ }^{*}$ indicates residual solvents and impurities. 


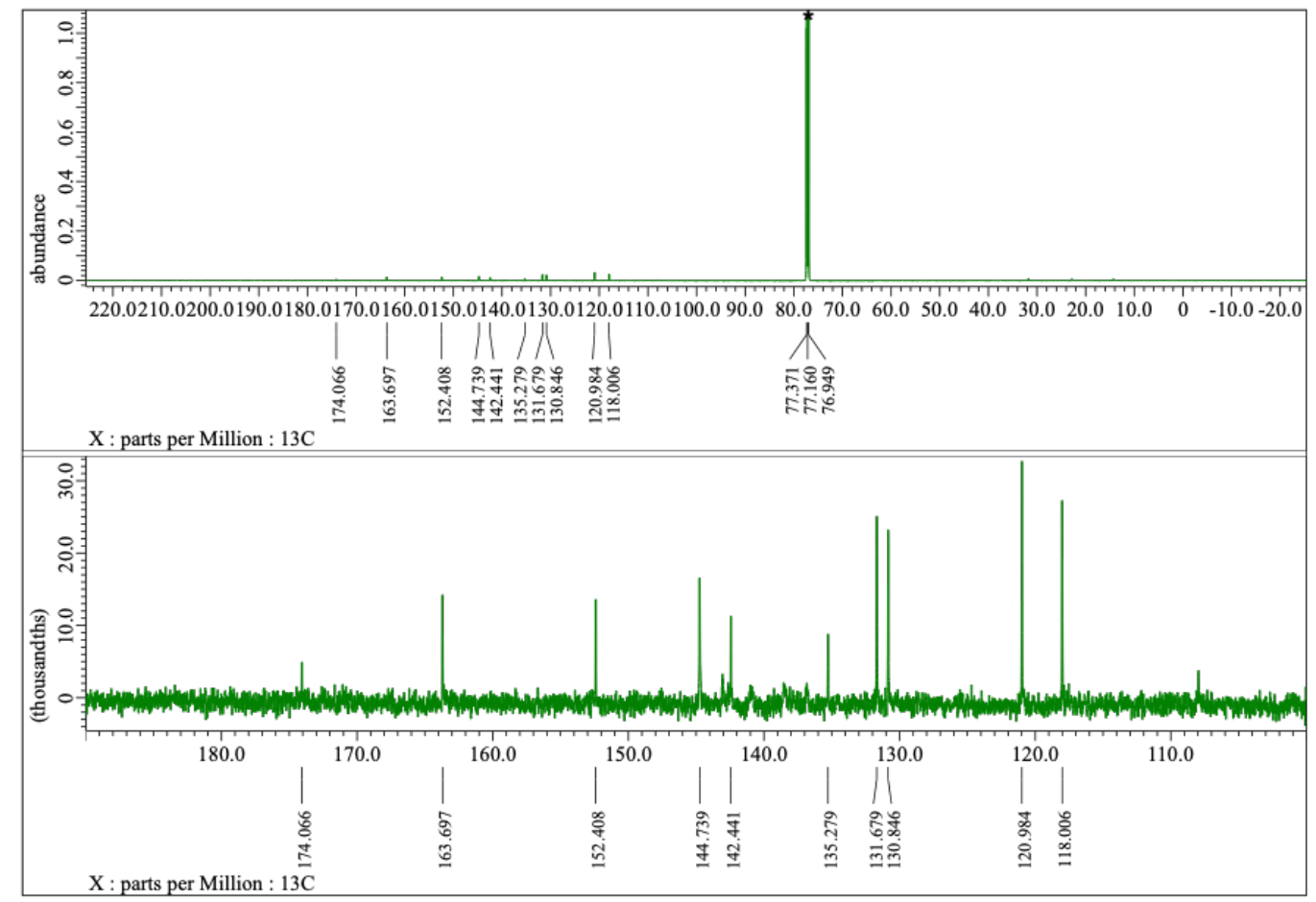

Figure S2-5. ${ }^{13} \mathrm{C}$ NMR spectrum of $4 \mathrm{Ni}$ in $\mathrm{CDCl}_{3}$ at $25{ }^{\circ} \mathrm{C}$. ${ }^{*}$ indicates residual solvents and impurities.

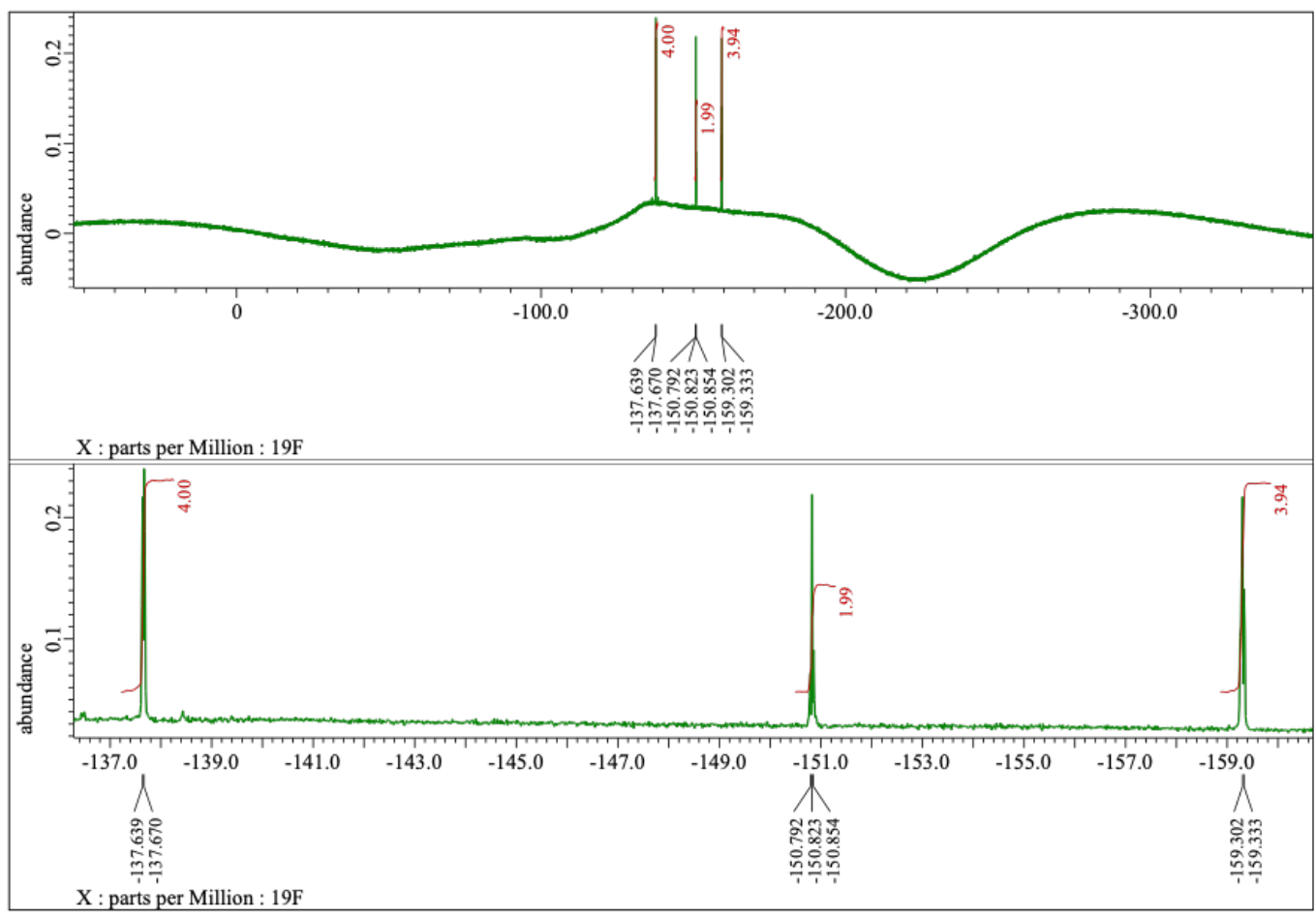

Figure S2-6. ${ }^{19} \mathrm{~F}$ NMR spectrum of $4 \mathrm{Ni}$ in $\mathrm{CDCl}_{3}$ at $25^{\circ} \mathrm{C}$. 




Figure S2-8. ${ }^{1} \mathrm{H}$ NMR spectrum of $4 \mathrm{Pd}$ in $\mathrm{CDCl}_{3}$ at $25{ }^{\circ} \mathrm{C}$. * indicates residual solvents and impurities.



Figure S2-9. ${ }^{13} \mathrm{C}$ NMR spectrum of $4 \mathrm{Pd}$ in $\mathrm{CDCl}_{3}$ at $25{ }^{\circ} \mathrm{C} .{ }^{*}$ indicates residual solvents and impurities. 




Figure S2-10. ${ }^{19} \mathrm{~F}$ NMR spectrum of $4 \mathrm{Pd}$ in $\mathrm{CDCl}_{3}$ at $25{ }^{\circ} \mathrm{C}$.

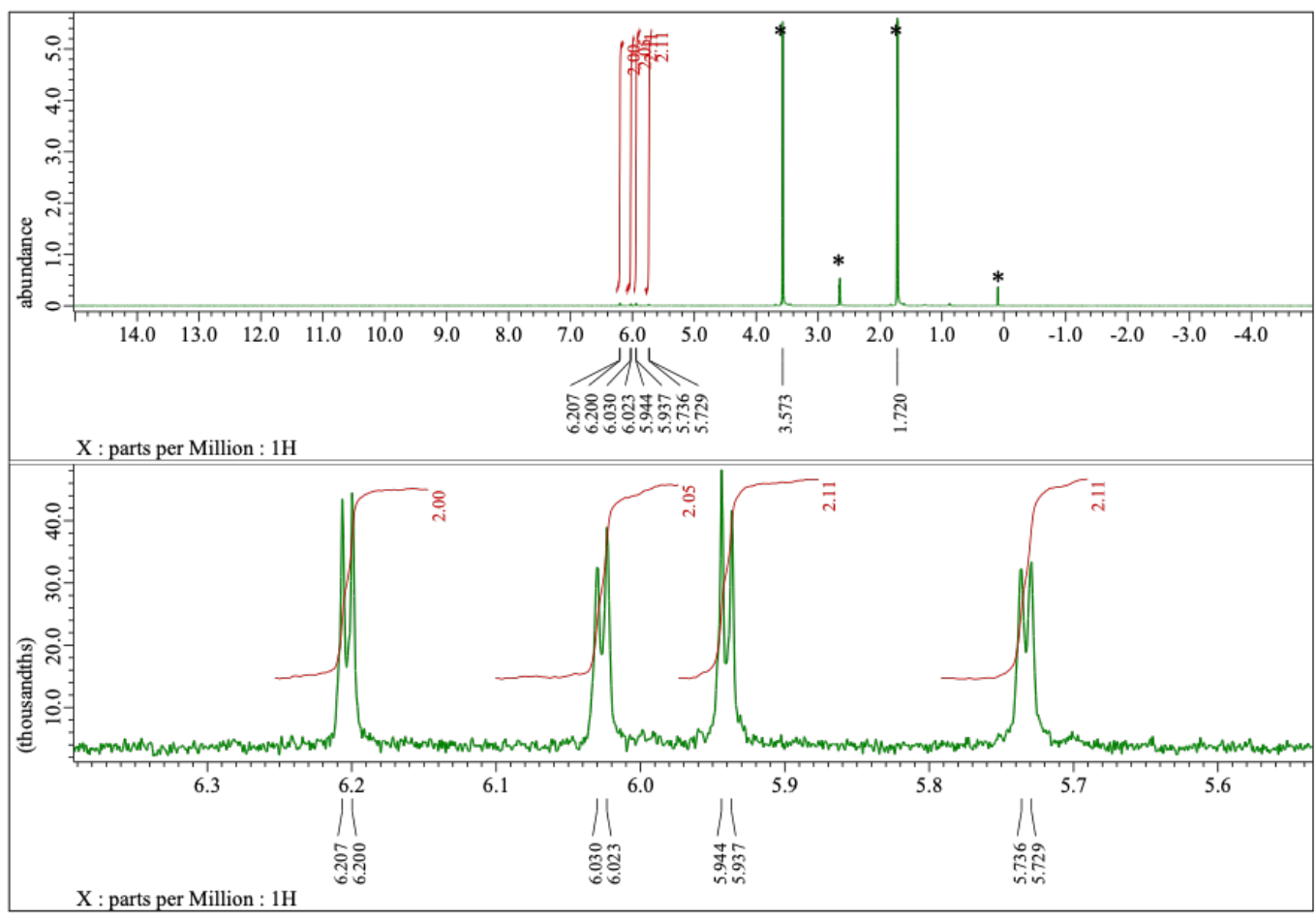

Figure S2-11. ${ }^{1} \mathrm{H}$ NMR spectrum of $4 \mathrm{Zn}$ in $\mathrm{CD} 8 \mathrm{O}\left(\mathrm{THF}-d_{8}\right)$ at $25{ }^{\circ} \mathrm{C}$. ${ }^{*}$ indicates residual solvents and impurities. 


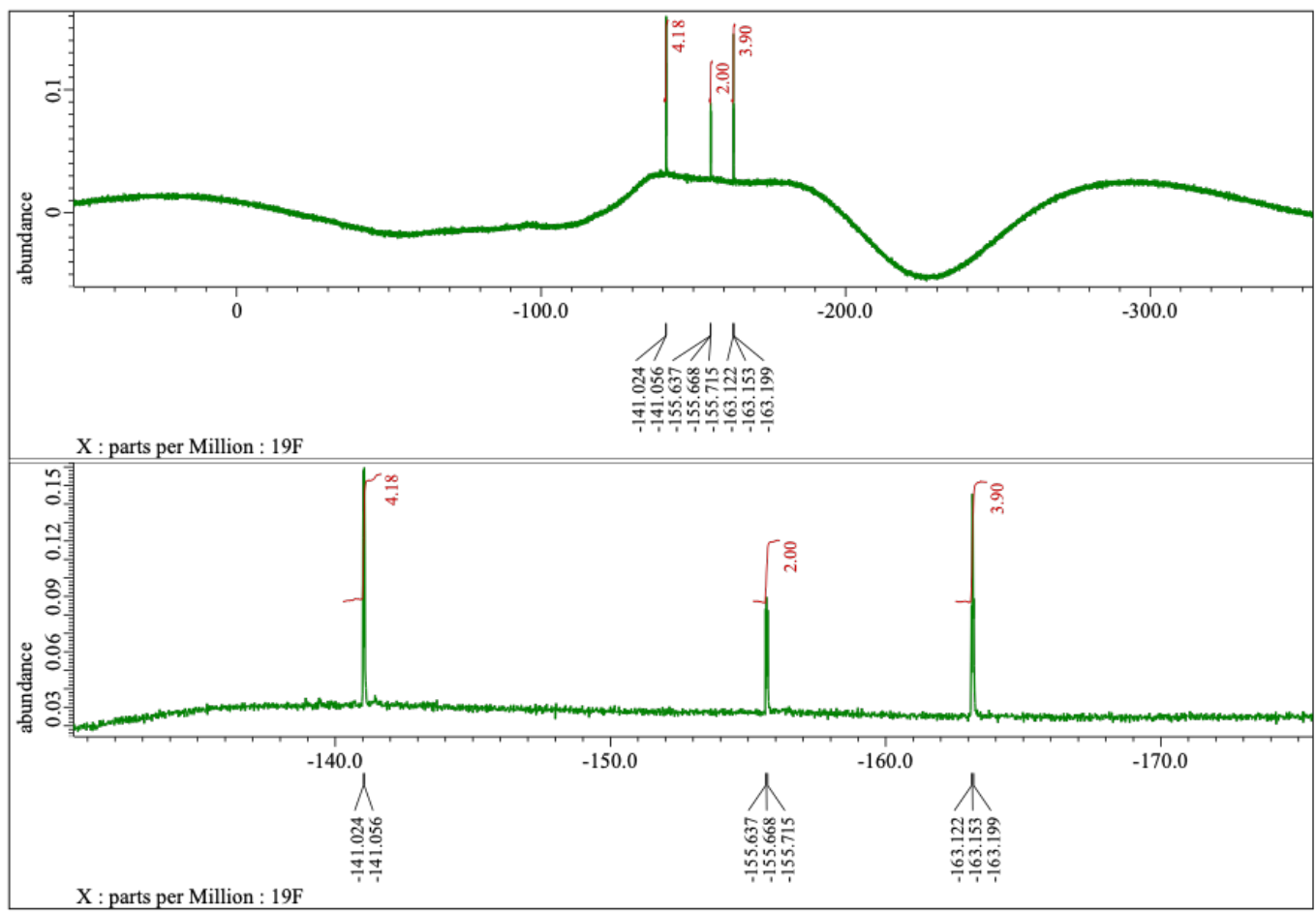

Figure S2-12. ${ }^{19} \mathrm{~F}$ NMR spectrum of $4 \mathrm{Zn}$ in $\mathrm{CD} 8 \mathrm{O}\left(\mathrm{THF}-d_{8}\right)$ at $25{ }^{\circ} \mathrm{C} .{ }^{*}$ indicates residual solvents and impurities.

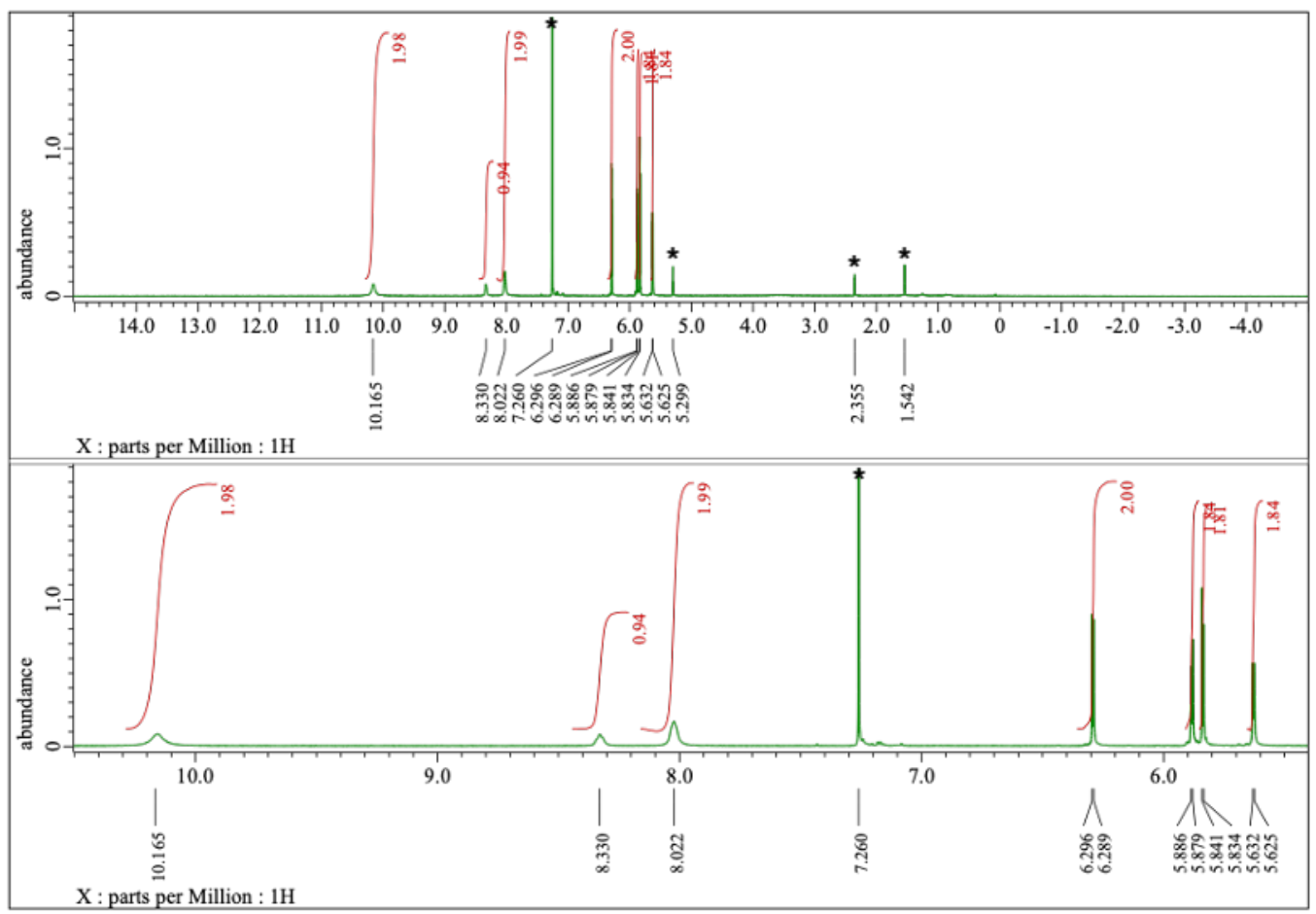

Figure S2-13. ${ }^{1} \mathrm{H}$ NMR spectrum of $4 \mathrm{ZnPy}$ in $\mathrm{CDCl}_{3}$ at $25{ }^{\circ} \mathrm{C} .{ }^{*}$ indicates residual solvents and impurities. 


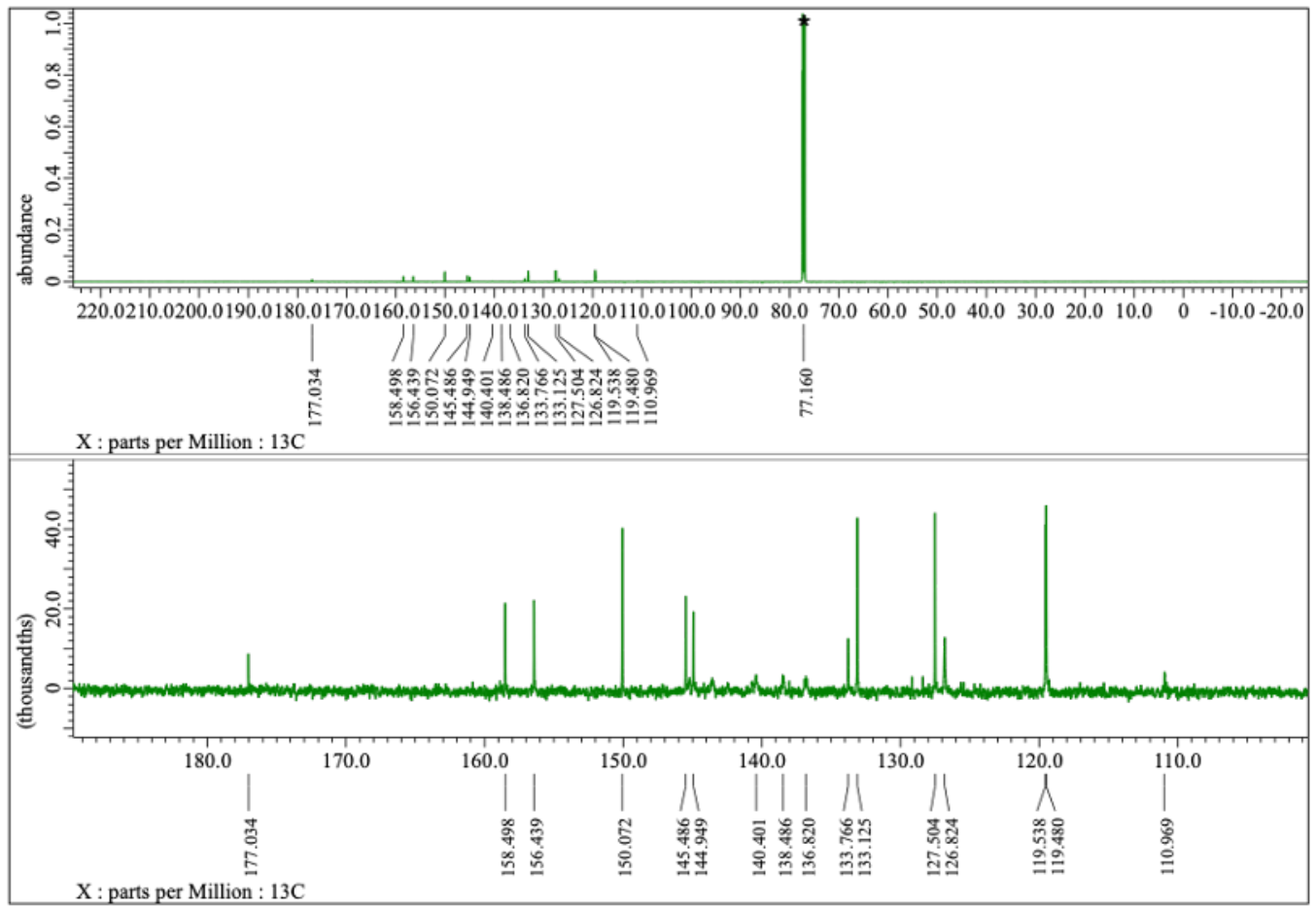

Figure S2-14. ${ }^{13} \mathrm{C}$ NMR spectrum of $4 \mathrm{ZnPy}$ in $\mathrm{CDCl}_{3}$ at $25{ }^{\circ} \mathrm{C} .{ }^{*}$ indicates residual solvents and impurities.

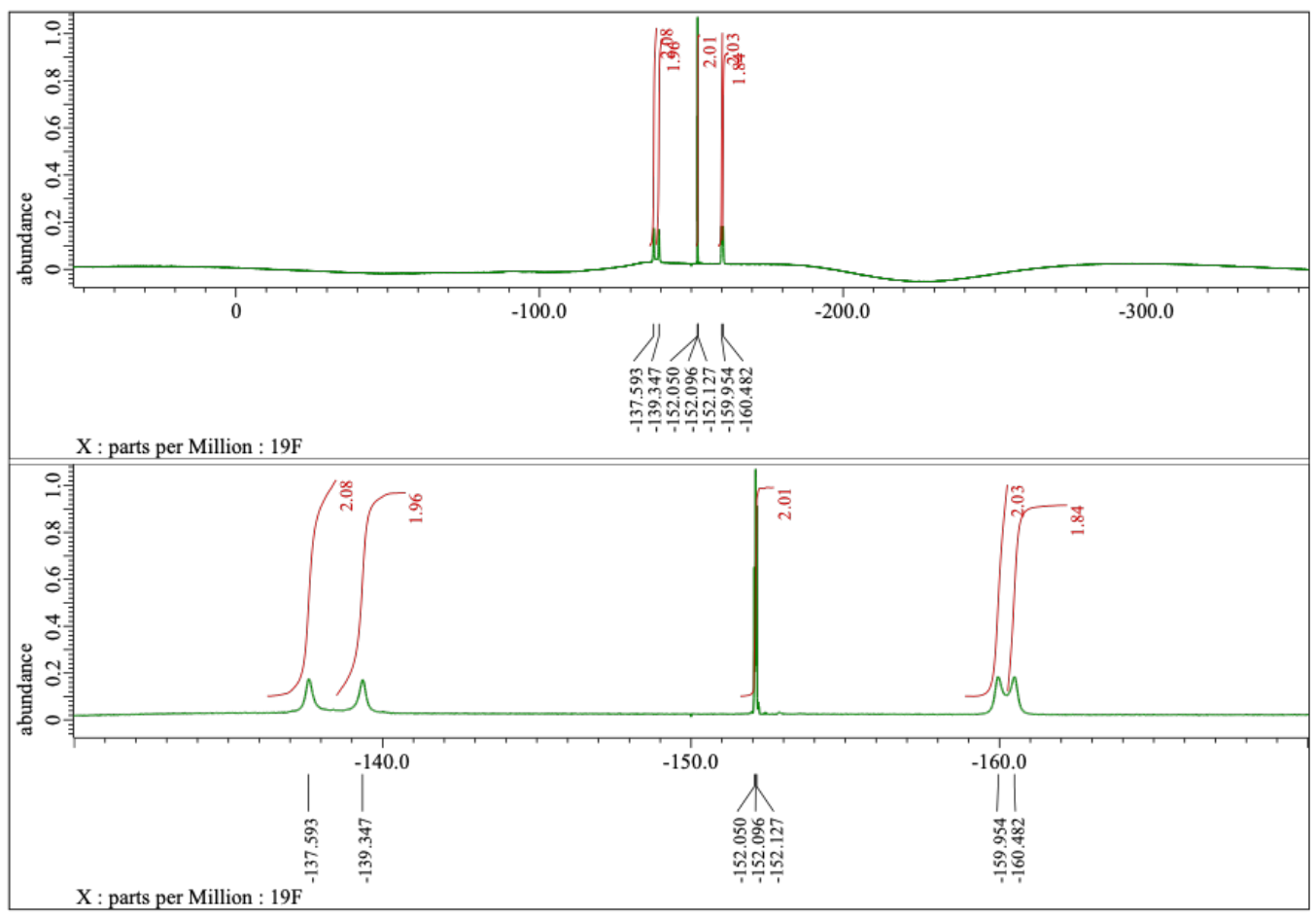

Figure S2-15. ${ }^{19} \mathrm{~F}$ NMR spectrum of $4 \mathrm{ZnPy}$ in $\mathrm{CDCl}_{3}$ at $25{ }^{\circ} \mathrm{C}$. 


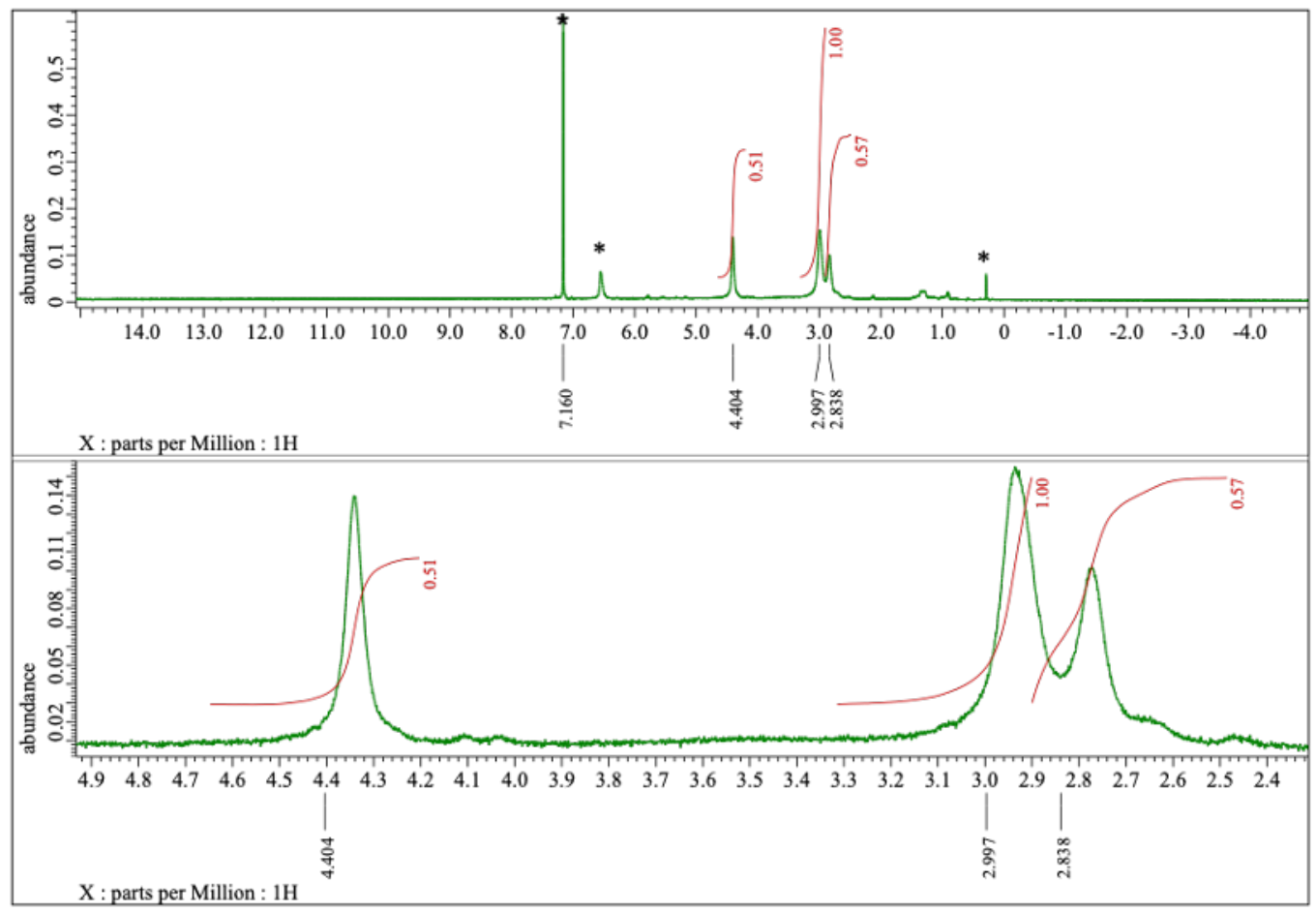

Figure S2-16. ${ }^{1} \mathrm{H}$ NMR spectrum of a mixture of $4 \mathrm{Ni}$ and 1 eq. $\mathrm{B}\left(\mathrm{C}_{6} \mathrm{~F}_{5}\right)_{3}$ in $\mathrm{C}_{6} \mathrm{D}_{6}$ at $25{ }^{\circ} \mathrm{C}$. ${ }^{*}$ indicates residual solvents and impurities.

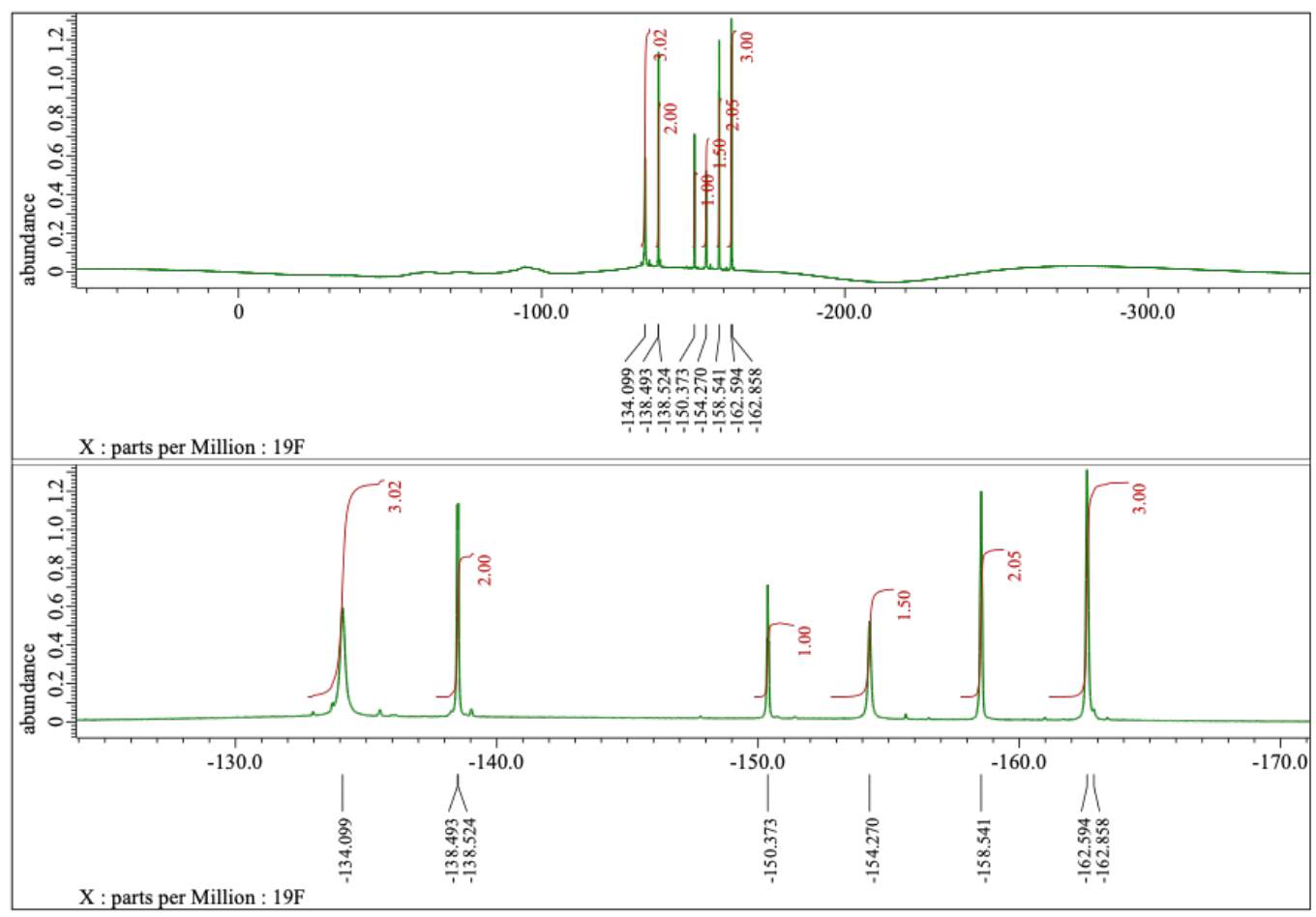

Figure S2-17. ${ }^{19} \mathrm{~F}$ NMR spectrum of a mixture of $4 \mathrm{Ni}$ and 1 eq. $\mathrm{B}\left(\mathrm{C}_{6} \mathrm{~F}_{5}\right)_{3}$ in $\mathrm{C}_{6} \mathrm{D}_{6}$ at $25{ }^{\circ} \mathrm{C}$. 

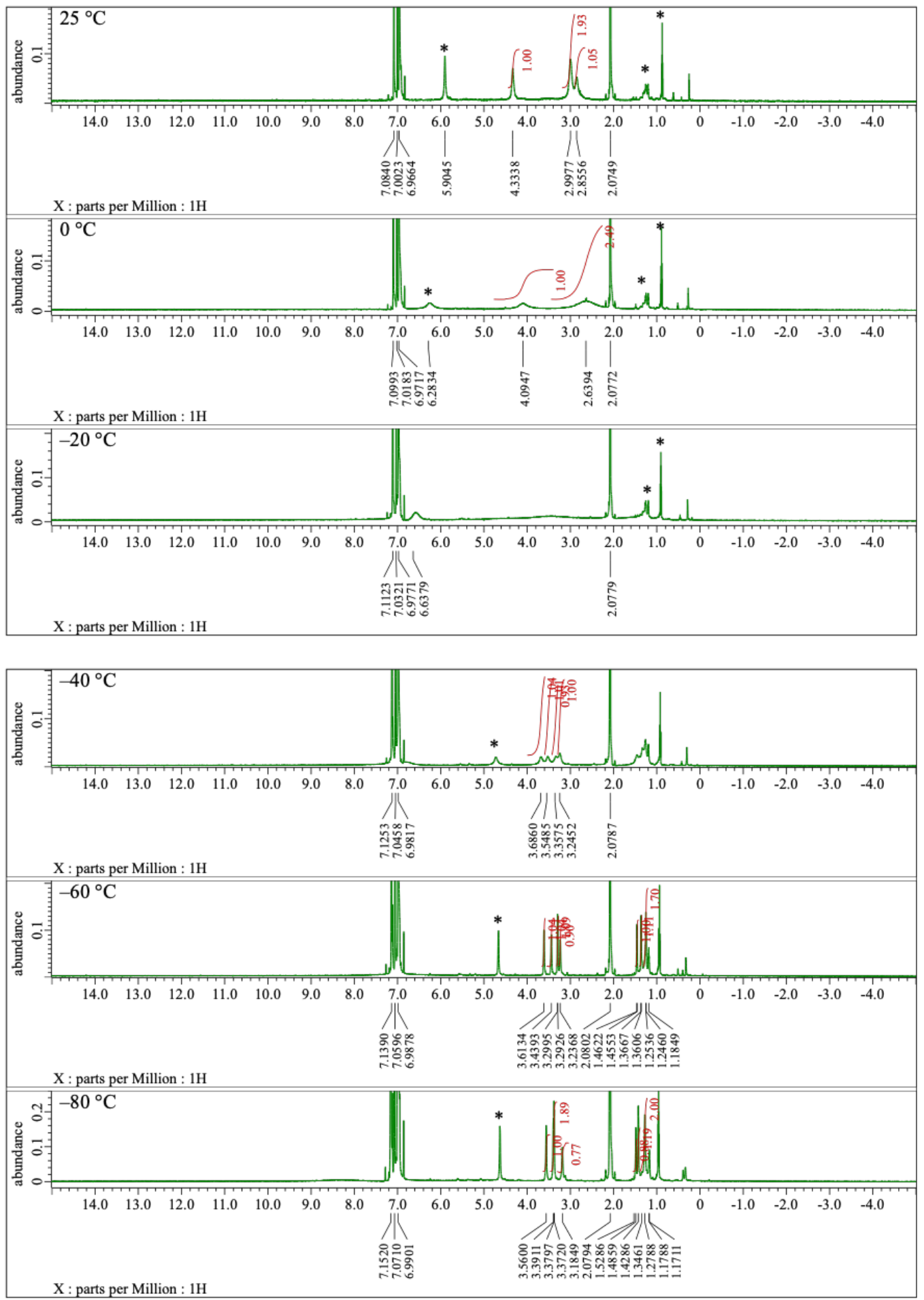

Figure S2-18. ${ }^{1} \mathrm{H}$ NMR spectra of a mixture of $4 \mathrm{Ni}$ and ca. 1 eq. $\mathrm{B}_{(}\left(\mathrm{C}_{6} \mathrm{~F}_{5}\right)_{3}$ in $\mathrm{C}_{7} \mathrm{D}_{8}$ (toluene- $d_{8}$ ) at several temperature. ${ }^{*}$ indicates residual solvents and impurities. 

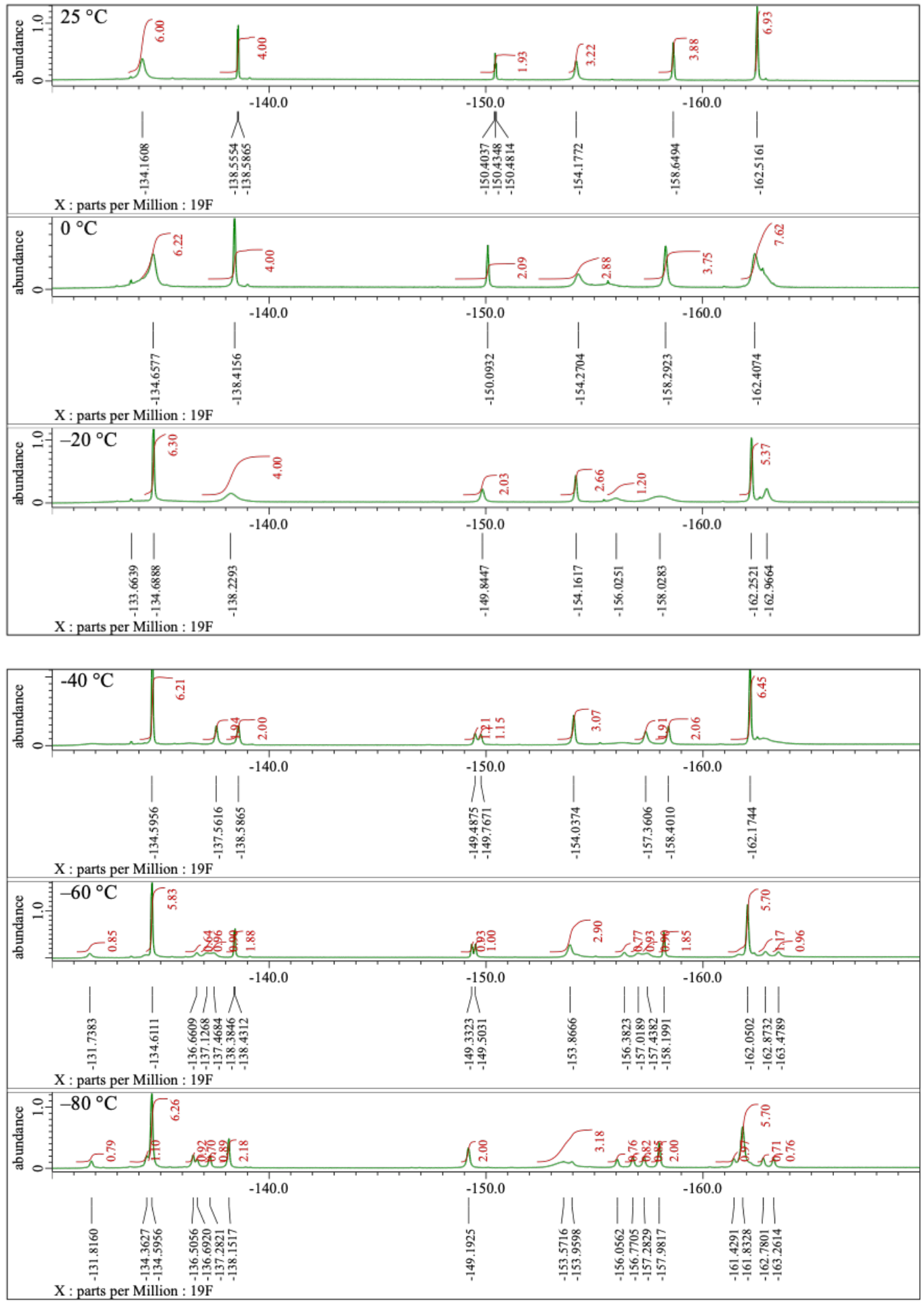

Figure S2-19. ${ }^{19} \mathrm{~F}$ NMR spectra of a mixture of $4 \mathrm{Ni}$ and ca. 1 eq. $\mathrm{B}\left(\mathrm{C}_{6} \mathrm{~F}_{5}\right)_{3}$ in $\mathrm{C}_{7} \mathrm{D}_{8}$ (toluene- $\left.d_{8}\right)$ at several temperature. ${ }^{*}$ indicates residual solvents and impurities. 


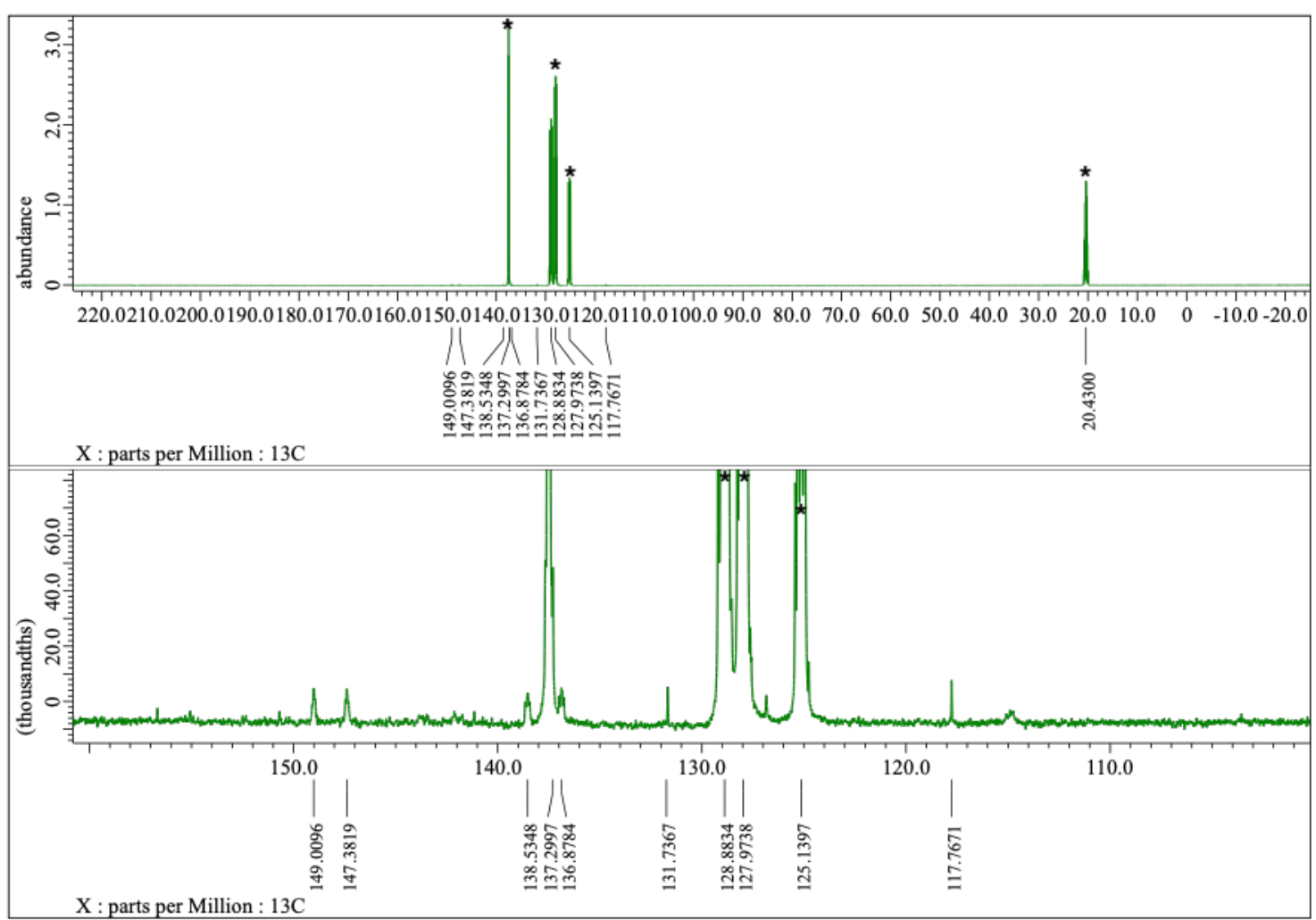

Figure S2-20. ${ }^{13} \mathrm{C}$ NMR spectrum of a mixture of $4 \mathrm{Ni}$ and $\mathrm{B}\left(\mathrm{C}_{6} \mathrm{~F}_{5}\right)_{3}$ in $\mathrm{C}_{7} \mathrm{D}_{8}$ (toluene$\left.d_{8}\right)$ at room temperature. ${ }^{*}$ indicates residual solvents and impurities. 


\section{Mass Spectra}

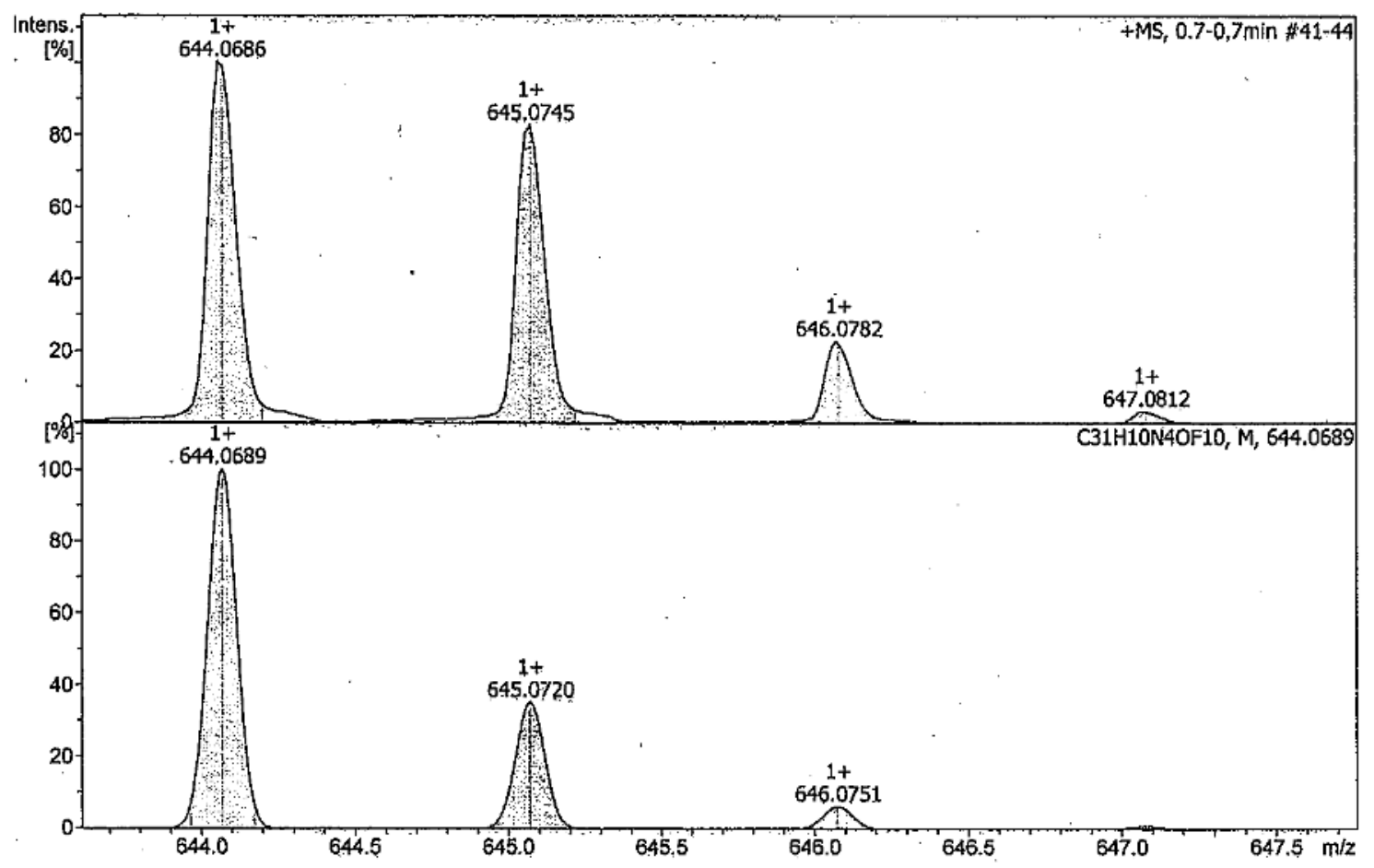

Figure S 3-1. Observed (top) and simulated (bottom) HR-APCI-TOF-MS of 4.

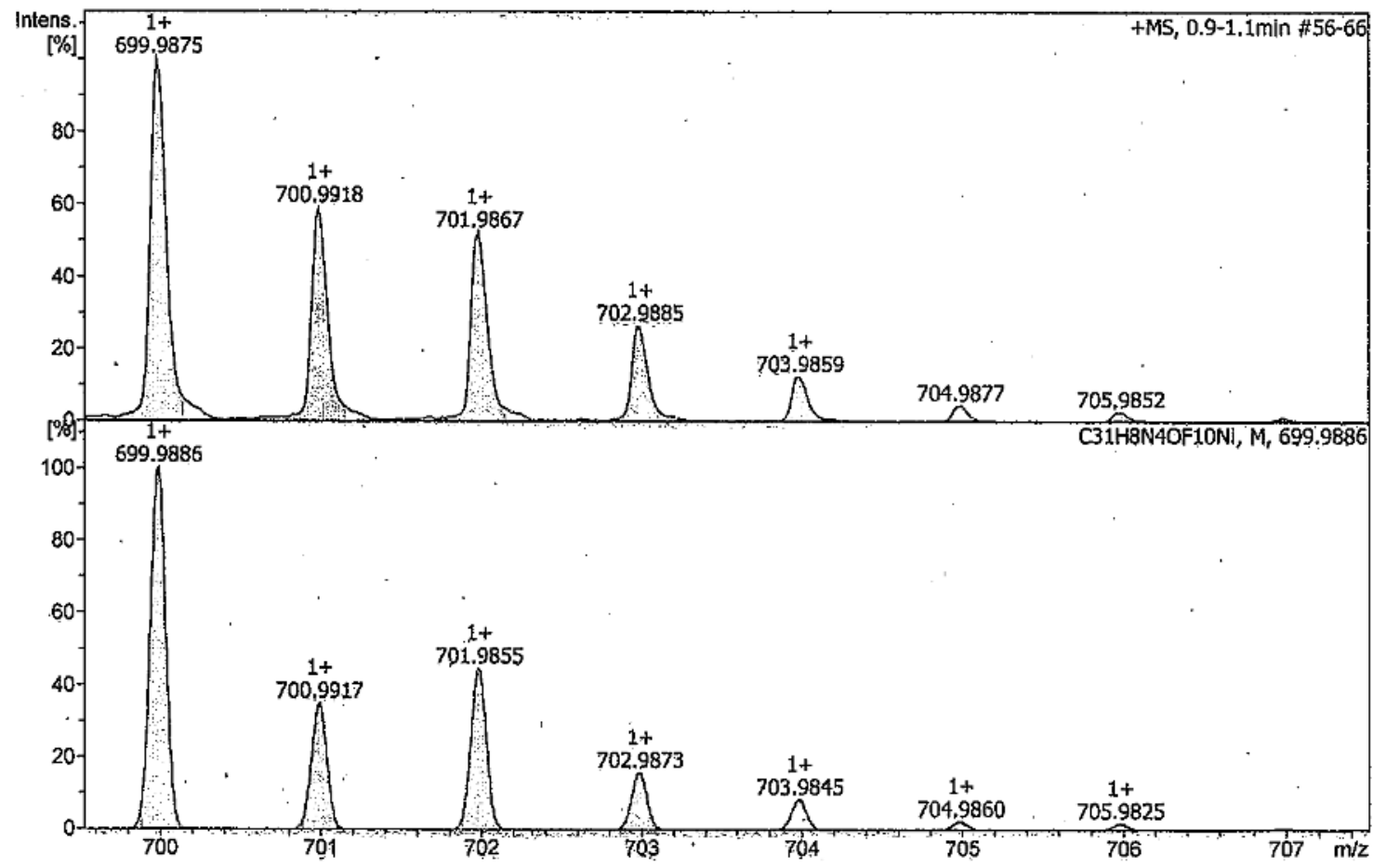

Figure S 3-2. Observed (top) and simulated (bottom) HR-APCI-TOF-MS of 4 Ni. 




Figure S 3-3. Observed (top) a[nd simulated (bottom) HR-APCI-TOF-MS of 4Pd.

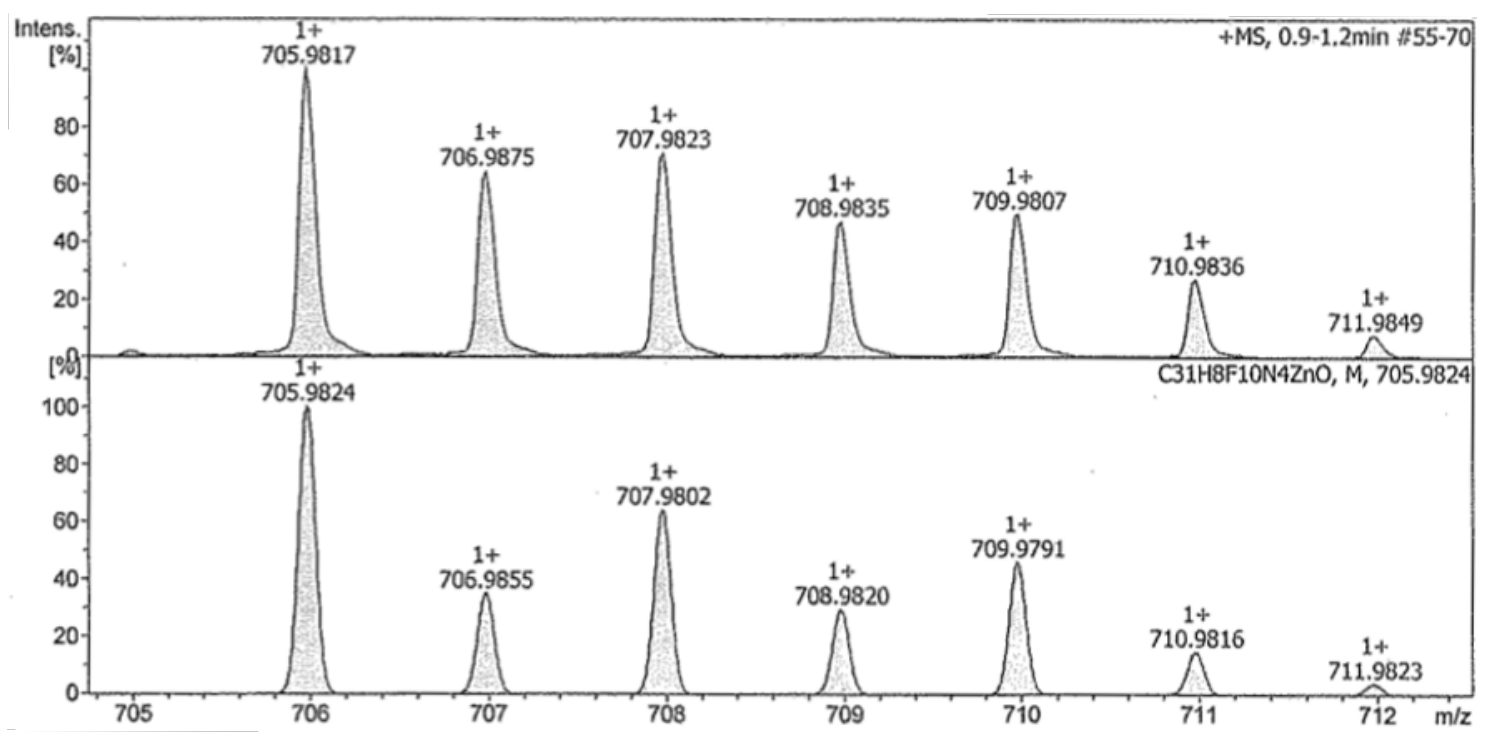

Figure S 3-4. Observed (top) and simulated (bottom) HR-APCI-TOF-MS of 4Zn. 


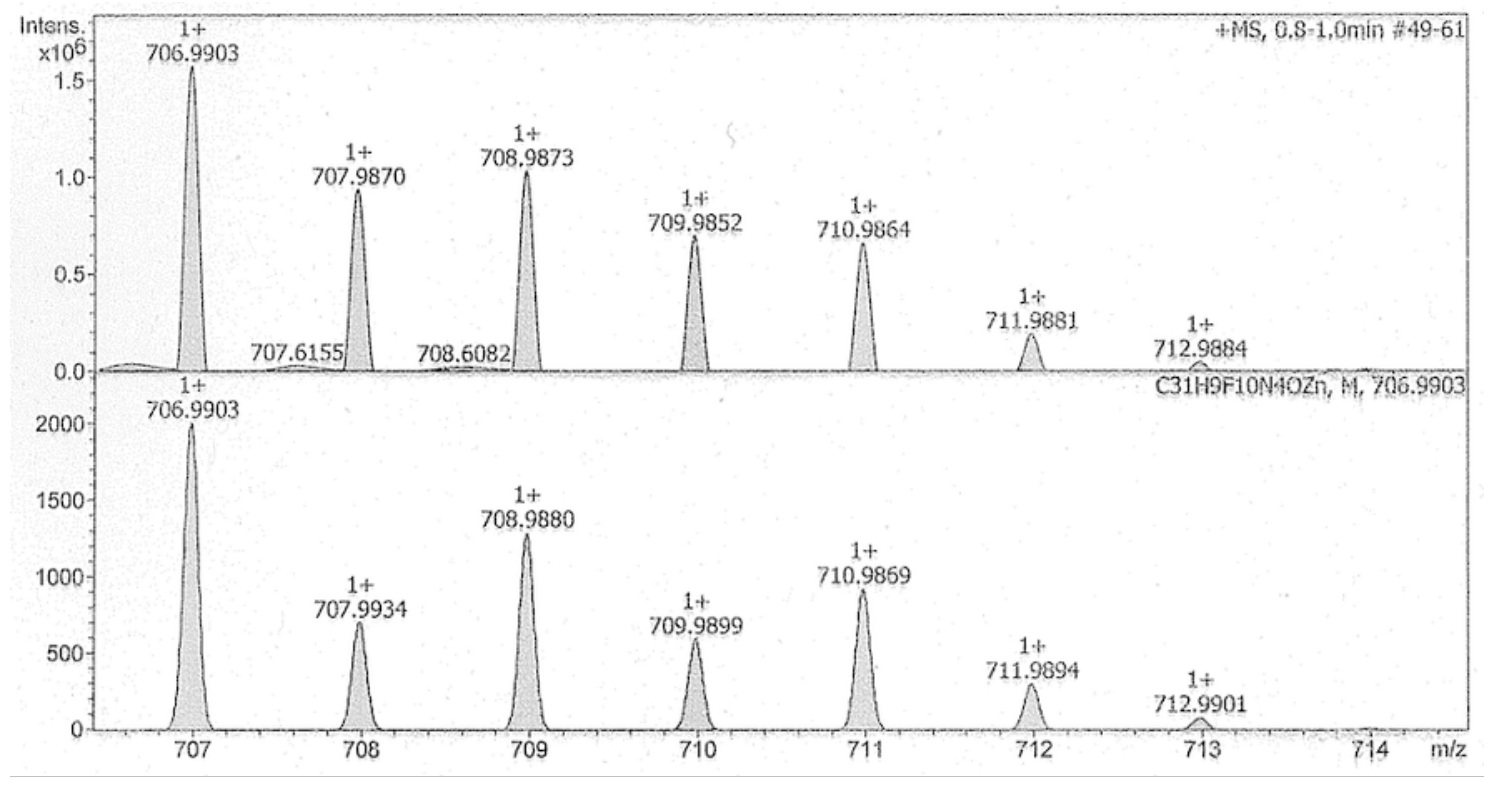

Figure S 3-5. Observed (top) and simulated (bottom) HR-APCI-TOF-MS of 4ZnPy. 


\section{UV/Vis Absorption Spectra}

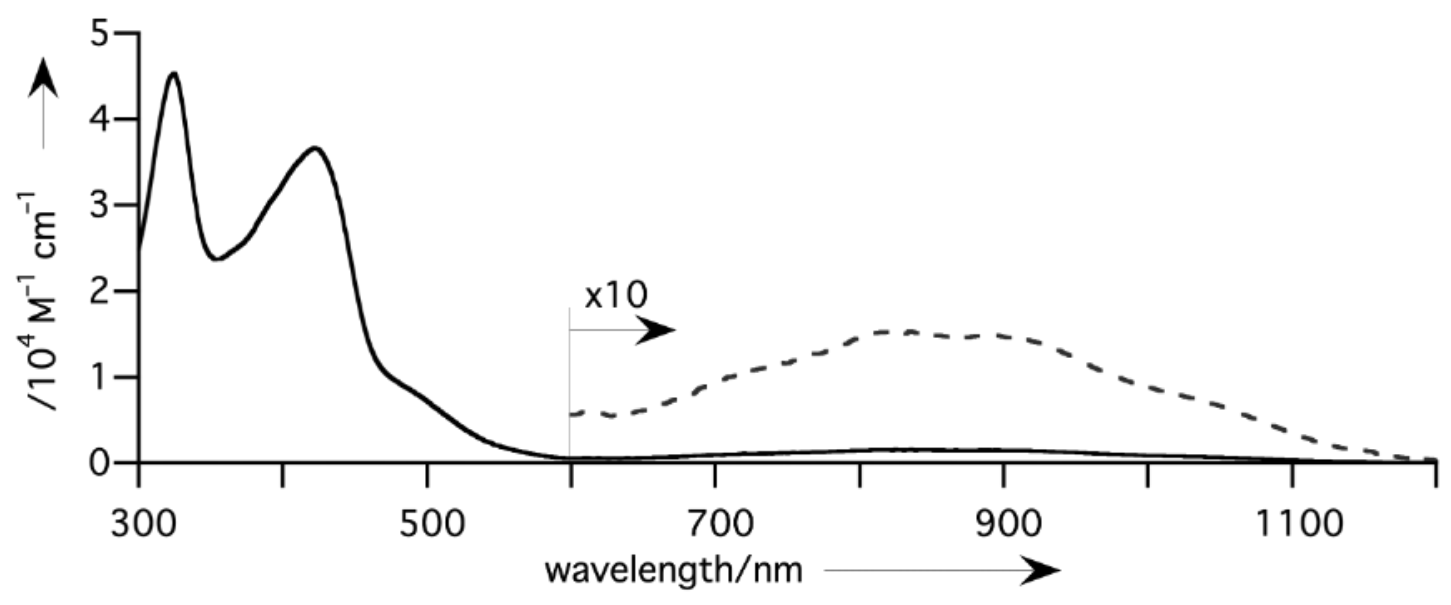

Figure $S$ 4-1. UV/Vis absorption spectrum of 4 in dichloromethane.

UV/Vis $\left(\mathrm{CH}_{2} \mathrm{Cl}_{2}\right): \lambda_{\max } / \mathrm{nm}\left(\varepsilon / \mathrm{M}^{-1} \mathrm{~cm}^{-1}\right)=325\left(4.53 \times 10^{4}\right), 422\left(3.67 \times 10^{4}\right)$, and 836 $\left(1.55 \times 10^{3}\right)$.

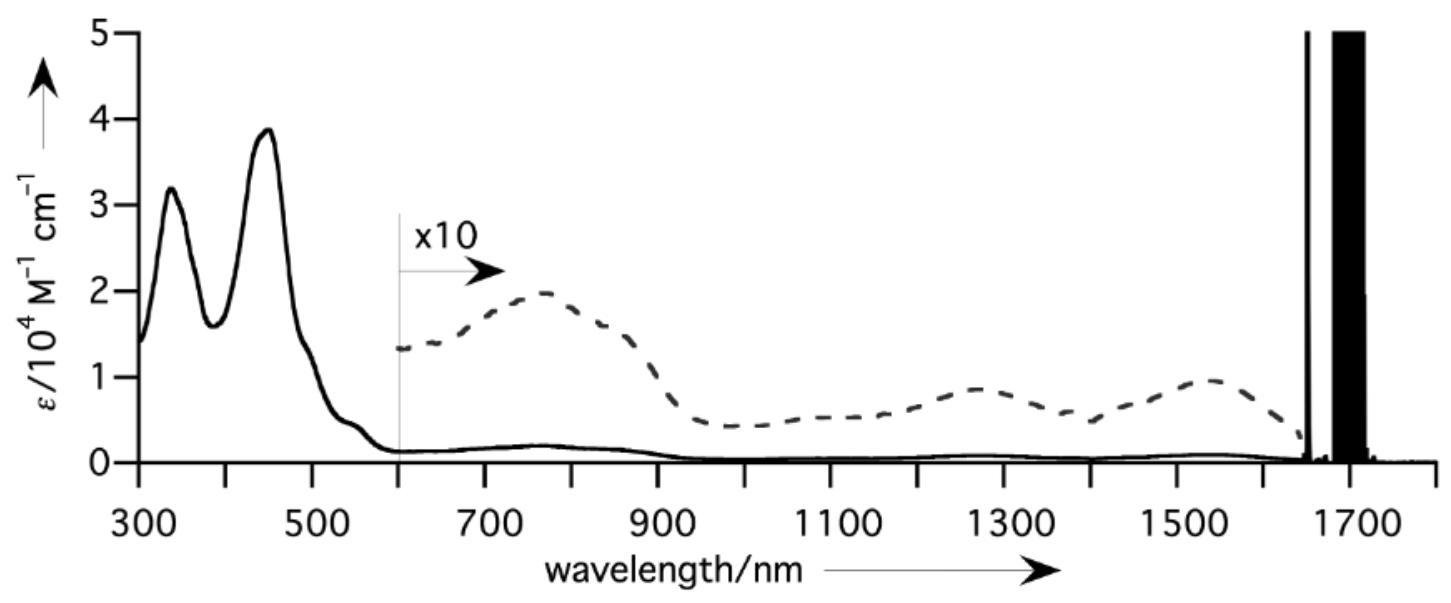

Figure $S 4-2$. UV/Vis absorption spectrum of $4 \mathbf{N i}$ in dichloromethane.

UV/Vis $\left(\mathrm{CH}_{2} \mathrm{Cl}_{2}\right): \lambda_{\max } / \mathrm{nm}\left(\varepsilon / \mathrm{M}^{-1} \mathrm{~cm}^{-1}\right)=338\left(3.19 \times 10^{4}\right), 450\left(3.88 \times 10^{5}\right), 764$ $\left(1.95 \times 10^{3}\right), 1271\left(8.61 \times 10^{2}\right)$, and $1532\left(9.65 \times 10^{2}\right)$. 


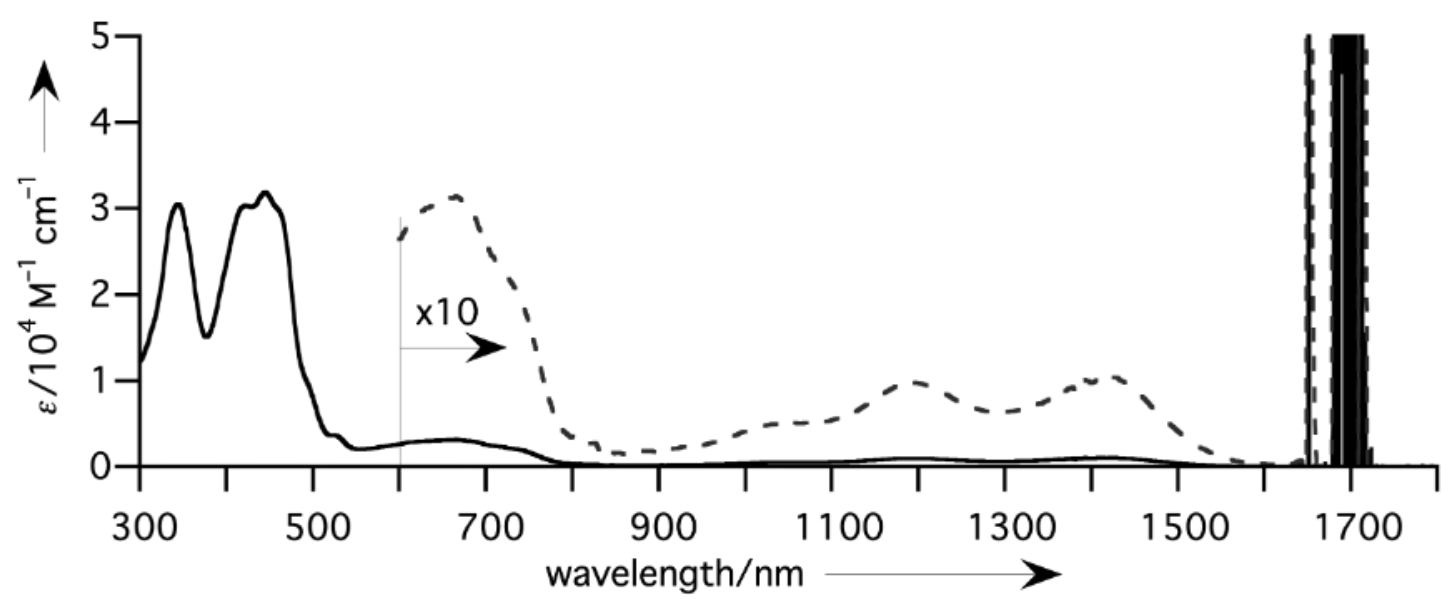

Figure $S$ 4-3. UV/Vis absorption spectrum of $\mathbf{4 P d}$ in dichloromethane.

UV/Vis $\left(\mathrm{CH}_{2} \mathrm{Cl}_{2}\right): \lambda_{\max } / \mathrm{nm}\left(\varepsilon / \mathrm{M}^{-1} \mathrm{~cm}^{-1}\right)=346\left(3.05 \times 10^{4}\right), 445\left(3.19 \times 10^{4}\right), 666$ $\left(3.17 \times 10^{3}\right), 1197\left(9.81 \times 10^{2}\right)$, and $1425\left(1.05 \times 10^{3}\right)$.



Figure $S 4-4$. UV/Vis absorption spectrum of $4 \mathrm{ZnPy}$ in dichloromethane.

$\mathrm{UV} / \mathrm{Vis}\left(\mathrm{CH}_{2} \mathrm{Cl}_{2}\right): \lambda_{\max } / \mathrm{nm}\left(\varepsilon / \mathrm{M}^{-1} \mathrm{~cm}^{-1}\right)=336\left(6.93 \times 10^{4}\right), 448\left(5.43 \times 10^{4}\right), 1037$ $\left(1.99 \times 10^{3}\right)$, and $1183\left(1.89 . \times 10^{3}\right)$. 


\section{X-Ray Crystallographic Details}

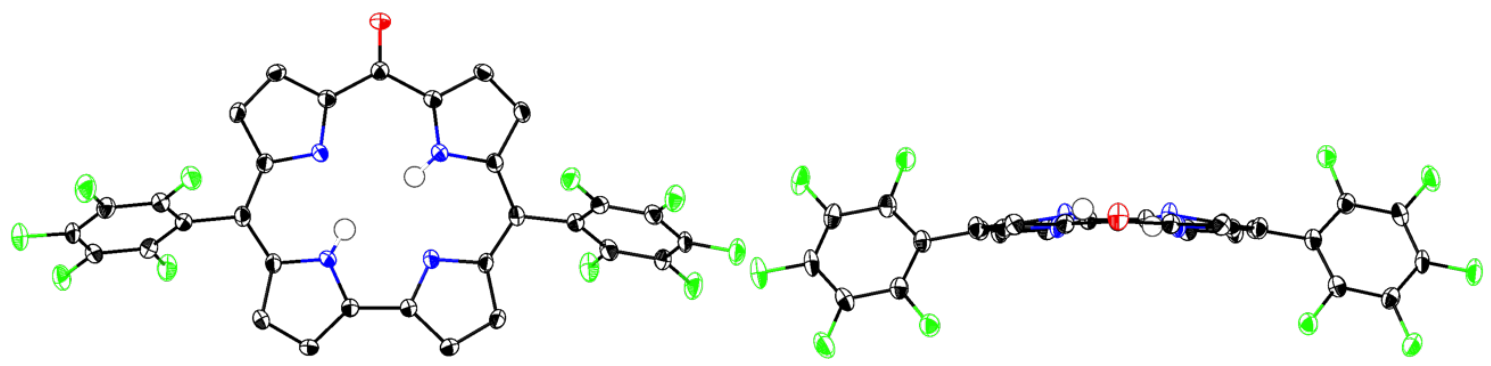

Figure S 5-1. X-Ray structure of 4. (left) Top view and (right) side view. Thermal ellipsoids are shown at the $50 \%$ probability level. Solvent molecules and all hydrogen atoms except for those of the NH moieties have been omitted for clarity.

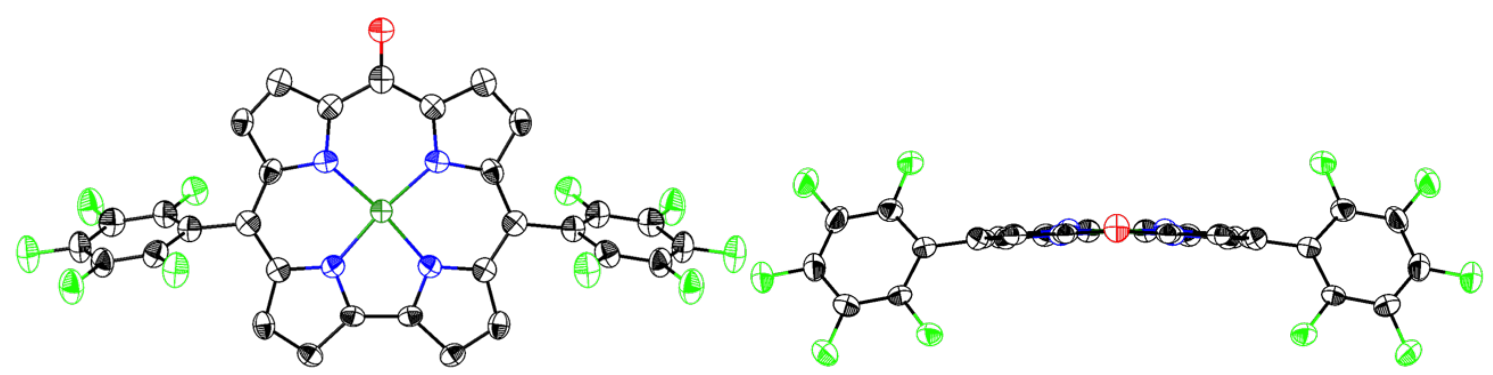

Figure S 5-2. X-Ray structure of $\mathbf{4 N i}$. (left) Top view and (right) side view. Thermal ellipsoids are shown at the $50 \%$ probability level. Solvent molecules and all hydrogen atoms have been omitted for clarity.

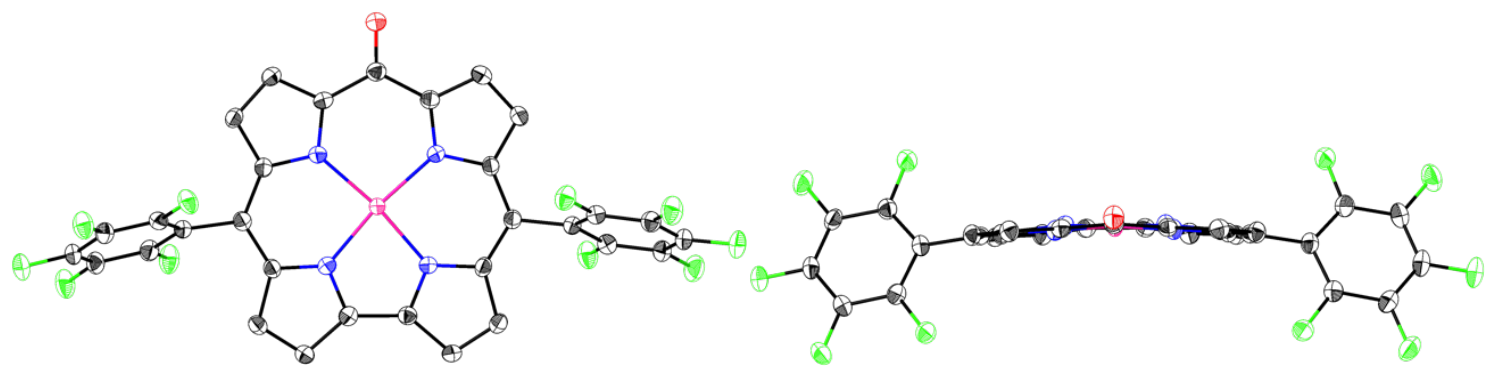

Figure S 5-3. X-Ray structure of $4 \mathbf{P d}$. (left) Top view and (right) side view. Thermal ellipsoids are shown at the 50\% probability level. Solvent molecules and all hydrogen atoms have been omitted for clarity. 



Figure S 5-4. X-Ray structure of $\mathbf{4 Z n}$. (left) Top view and (right) side view. Thermal ellipsoids are shown at the $50 \%$ probability level. Solvent molecules and all hydrogen atoms have been omitted for clarity.



Figure S 5-5. X-Ray structure of 4ZnPy. (left) Top view and (right) side view. Thermal ellipsoids are shown at the $50 \%$ probability level. Solvent molecules and all hydrogen atoms have been omitted for clarity.


Figure S 5-6. X-Ray structure of $4 \mathrm{Ni} \cdot \mathrm{B}\left(\mathrm{C}_{6} \mathrm{~F}_{5}\right)_{3}$. (left) Top view and (right) side view. Thermal ellipsoids are shown at the $50 \%$ probability level. Solvent molecules and all hydrogen atoms have been omitted for clarity. 

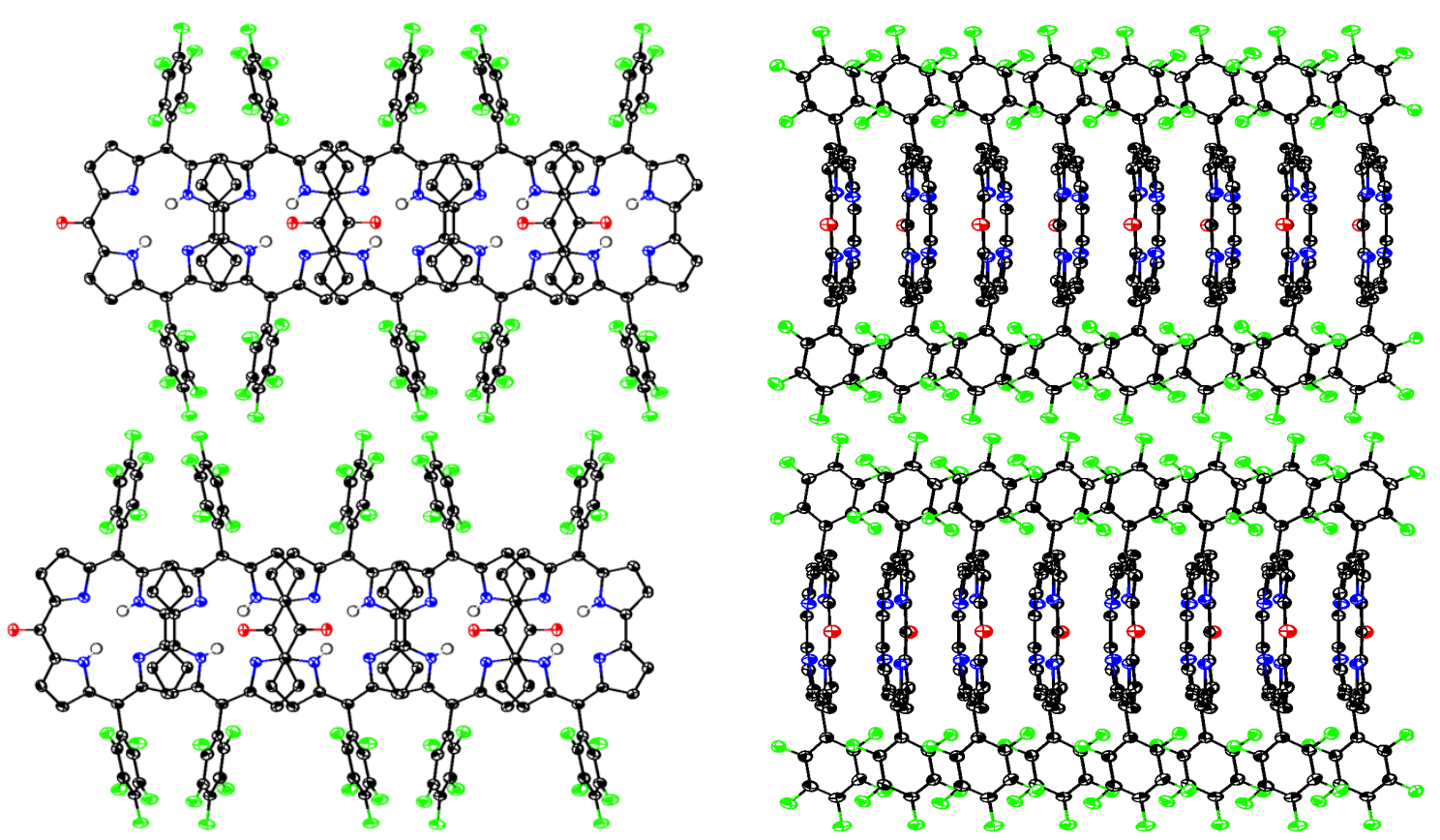

Figure S 5-7. X-Ray packing structure of 4. (left) Top view and (right) side view. Thermal ellipsoids are shown at the $50 \%$ probability level. Solvent molecules and hydrogen atoms except for those of the NH moieties have been omitted for clarity.
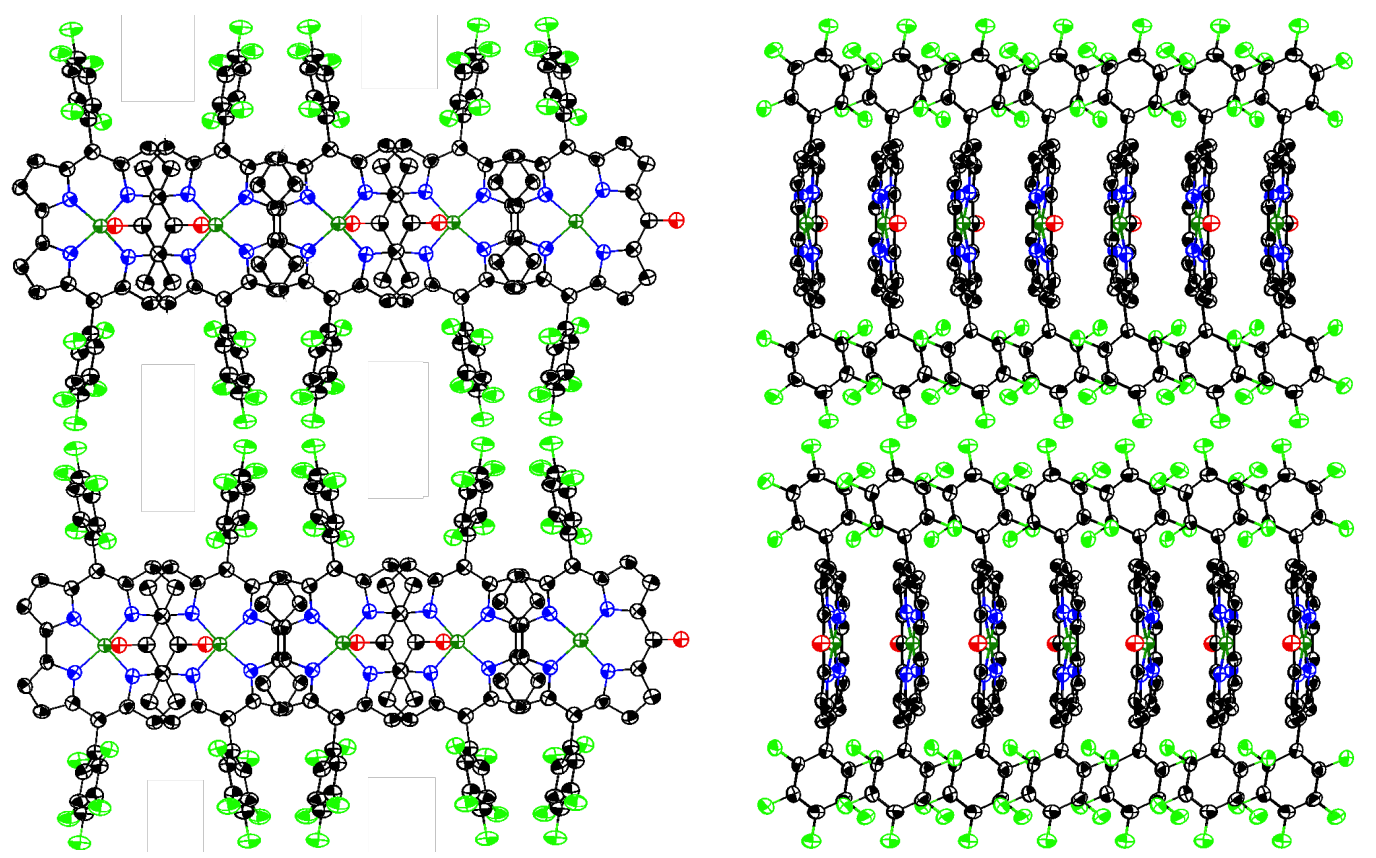

Figure S 5-8. X-Ray packing structure of 4Ni. (left) Top view and (right) side view. Thermal ellipsoids are shown at the $50 \%$ probability level. Solvent molecules and all hydrogen atoms have been omitted for clarity. 

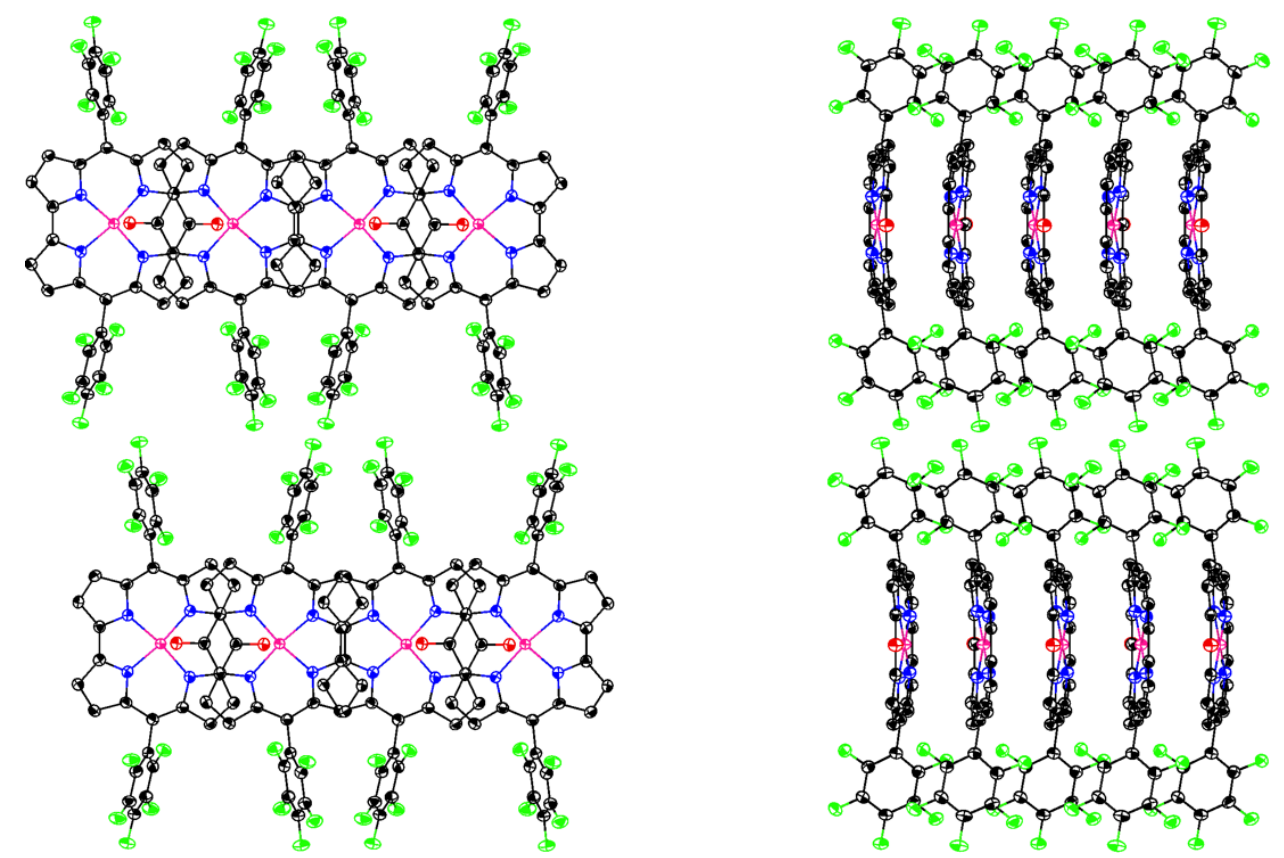

Figure S 5-9. X-Ray packing structure of 4Pd. (left) Top view and (right) side view. Thermal ellipsoids are shown at the $50 \%$ probability level. Solvent molecules and all hydrogen atoms have been omitted for clarity.

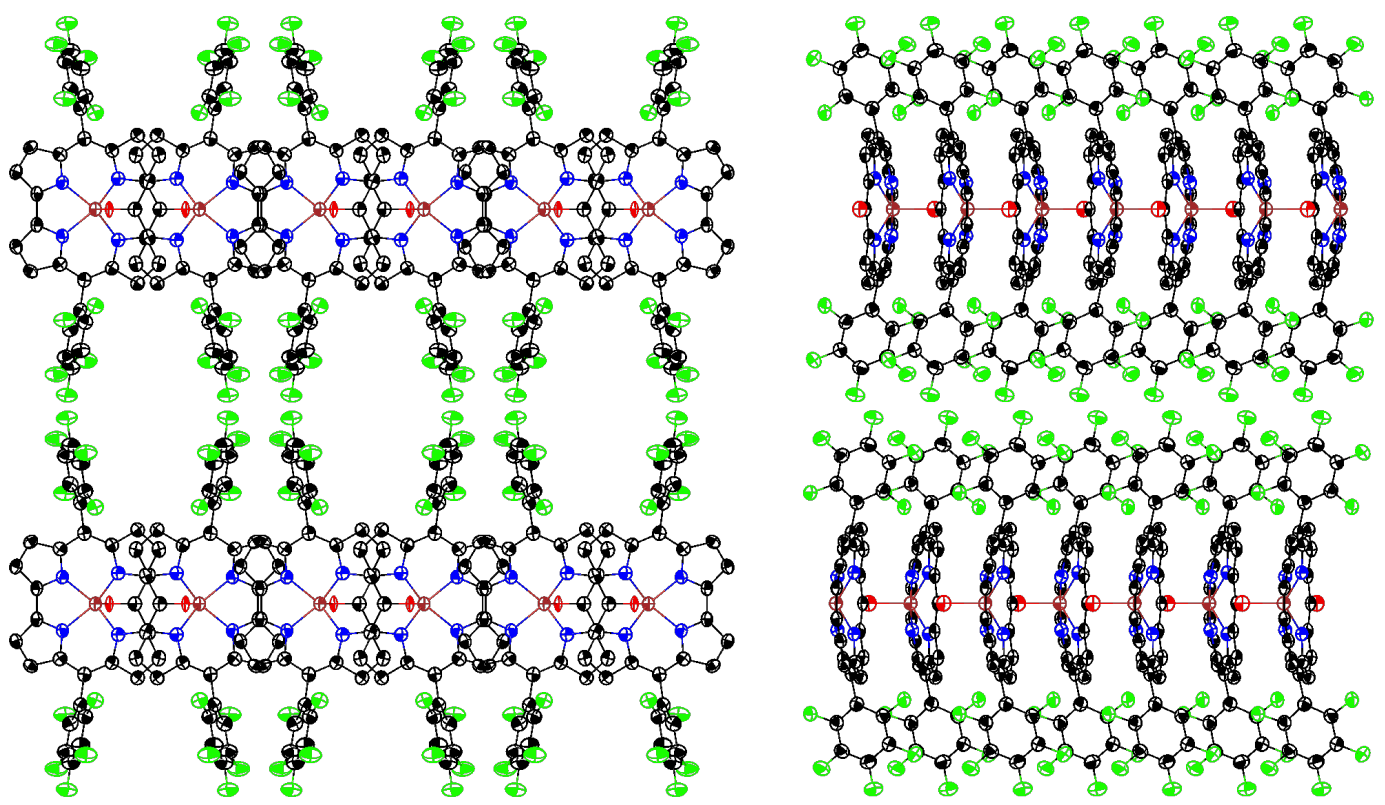

Figure S 5-10. X-Ray packing structure of $\mathbf{4 Z n}$. (left) Top view and (right) side view. Thermal ellipsoids are shown at the 50\% probability level. Solvent molecules and all hydrogen atoms have been omitted for clarity. 

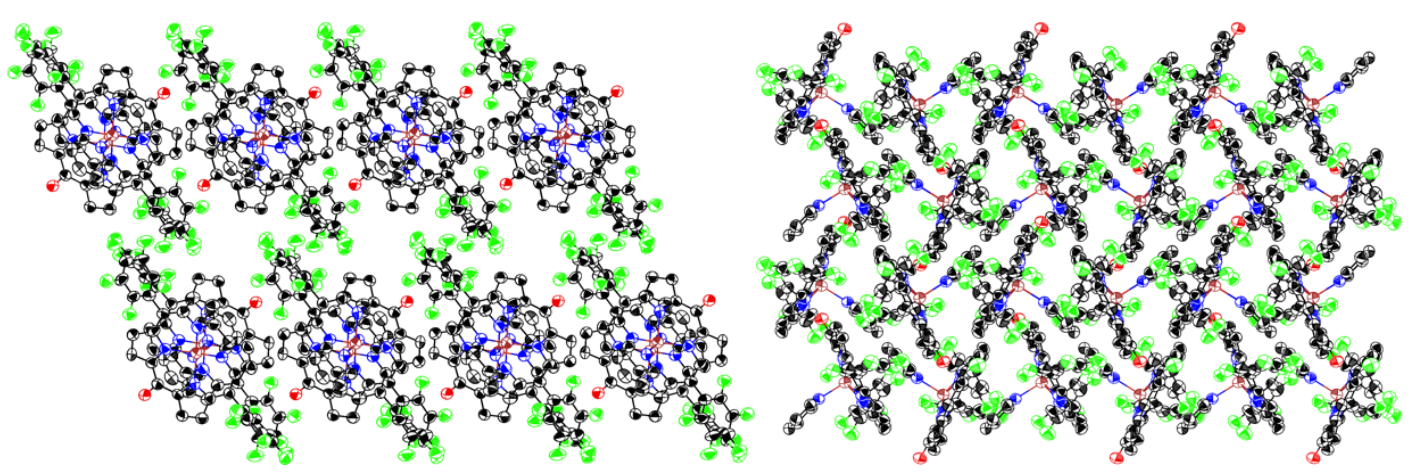

Figure S 5-11. X-Ray packing structure of 4ZnPy. (left) Top view and (right) side view. Thermal ellipsoids are shown at the 50\% probability level. Solvent molecules and all hydrogen atoms have been omitted for clarity.



Figure S 5-12. X-Ray packing structure of $4 \mathrm{Ni} \cdot \mathrm{B}\left(\mathrm{C}_{6} \mathrm{~F}_{5}\right)_{3}$. (left) Top view and (right) side view. Thermal ellipsoids are shown at the 50\% probability level. Solvent molecules and all hydrogen atoms have been omitted for clarity. 
Table S 5-1. Crystal data and structure refinements for $\mathbf{4}$ and $\mathbf{4 N i}$.

\begin{tabular}{l|ll} 
Compound & $\mathbf{4}$ & $\mathbf{4 N i}$ \\
\hline Empirical Formula & $\mathrm{C}_{31} \mathrm{H}_{10} \mathrm{~F}_{10} \mathrm{~N}_{4} \mathrm{O} \cdot \mathrm{CH}_{2} \mathrm{Cl}_{2}$ & $\mathrm{C}_{31} \mathrm{H}_{8} \mathrm{~F}_{10} \mathrm{~N}_{4} \mathrm{NiO} \cdot$ \\
& 729.36 & $0.5\left(\mathrm{C}_{2} \mathrm{H}_{4} \mathrm{Cl}_{2}\right)$ \\
Fw & Monoclinic & 750.60 \\
Crystal System & $P 21 / c(\mathrm{No} .14)$ & Orthorhombic \\
Space Group & $10.543(4)$ & $P b c m(\mathrm{No} .57)$ \\
$a / \AA$ & $6.952(4)$ & $10.6161(3)$ \\
$b / \AA$ & $37.530(13)$ & $6.9852(2)$ \\
$c / \AA$ & $90^{\circ}$ & $37.5252(13)$ \\
$\alpha$ & $96.798(12)^{\circ}$ & $90^{\circ}$ \\
$\beta$ & $90^{\circ}$ & $90^{\circ}$ \\
$\gamma$ & $2731(2)$ & $90^{\circ}$ \\
Volume / $\AA^{3}$ & 4 & $2782.70(15)$ \\
$Z$ & $1.774 \mathrm{~g}^{\circ} \cdot \mathrm{cm}^{-3}$ & 4 \\
Density (calcd.) & 0.976 & $1.792 \mathrm{~g} \cdot \mathrm{cm}^{-3}$ \\
Completeness & 1.030 & 0.997 \\
Goodness-of-fit & 0.0374 & 1.007 \\
$R_{1}(\mathrm{I}>2 \sigma(I))$ & 0.1139 & 0.0877 \\
$w R_{2}$ (all data) & 2052325 & 0.3059 \\
CCDC No. & & 2052330 \\
\hline
\end{tabular}


Table S 5-2. Crystal data and structure refinements for $\mathbf{4 P d}$ and $\mathbf{4 Z n}$.

\begin{tabular}{l|ll} 
Compound & $4 \mathbf{P d}$ & $\mathbf{4 Z n}$ \\
\hline Empirical Formula & $\mathrm{C}_{31} \mathrm{H}_{8} \mathrm{~F}_{10} \mathrm{~N}_{4} \mathrm{OPd} \cdot \mathrm{CH}_{2} \mathrm{Cl}_{2}$ & $\mathrm{C}_{31} \mathrm{H}_{8} \mathrm{~F}_{10} \mathrm{~N}_{4} \mathrm{OZn} \cdot 2\left(\mathrm{C}_{6} \mathrm{H}_{14}\right)$ \\
Fw & 833.74 & 793.98 \\
Crystal System & Monoclinic & Orthorhombic \\
Space Group & $P 21 / \mathrm{c}(\mathrm{No} .14)$ & $P b c m(\mathrm{No} .57)$ \\
$a / \AA$ & $10.8120(2)$ & $10.639(4)$ \\
$b / \AA$ & $6.9593(1)$ & $7.0596(19)$ \\
$c / \AA$ & $37.1952(5)$ & $37.325(11)$ \\
$\alpha$ & $90^{\circ}$ & $90^{\circ}$ \\
$\beta$ & $96.469(1)^{\circ}$ & $90^{\circ}$ \\
$\gamma$ & $90^{\circ}$ & $90^{\circ}$ \\
Volume / ${ }^{3}$ & $2780.89(8)$ & $2803.4(15)$ \\
$Z$ & 4 & 4 \\
Density (calcd.) & $1.991 \mathrm{~g} \cdot \mathrm{cm}^{-3}$ & $1.881 \mathrm{~g} \cdot \mathrm{cm}^{-3}$ \\
Completeness & 0.974 & 0.999 \\
Goodness-of-fit & 1.028 & 1.079 \\
$R_{1}(I>2 \sigma(I))$ & 0.0337 & 0.0982 \\
wR & 0.0841 & 0.3166 \\
CCDC No. & 2052327 & 2052326 \\
\hline & &
\end{tabular}


Table S 5-3. Crystal data and structure refinements for $4 \mathrm{ZnPy}$ and $4 \mathrm{Ni} \cdot \mathrm{B}\left(\mathrm{C}_{6} \mathrm{~F}_{5}\right)_{3}$.

\begin{tabular}{l|ll} 
Compound & $4 \mathrm{ZnPy}$ & $4 \mathrm{Ni} \cdot \mathrm{B}\left(\mathrm{C}_{6} \mathrm{~F}_{5}\right)_{3}$ \\
\hline Empirical Formula & $\mathrm{C}_{36} \mathrm{H}_{14} \mathrm{~F}_{10} \mathrm{~N}_{5} \mathrm{OZn} \cdot \mathrm{CHCl}_{3}$ & $2\left(\mathrm{C}_{49} \mathrm{H}_{8} \mathrm{BF}_{25} \mathrm{~N}_{4} \mathrm{NiO}\right) \cdot 4\left(\mathrm{C}_{7} \mathrm{H}_{8}\right)$ \\
Fw & 906.25 & 2794.76 \\
Color of Crystal & Orange & Brown \\
Crystal System & Monoclinic & Triclinic \\
Space Group & $P 21 / \mathrm{c}(\mathrm{No} \cdot 14)$ & $P-1(\mathrm{No} \cdot 2)$ \\
$a / \AA$ & $14.0323(9)$ & $14.6545(4)$ \\
$b / \AA$ & $12.9551(8)$ & $16.8644(4)$ \\
$c / \AA$ & $19.4444(14)$ & $22.5688(2)$ \\
$\alpha$ & $90^{\circ}$ & $93.970(1)^{\circ}$ \\
$\beta$ & $105.933(7)^{\circ}$ & $95.379(1)^{\circ}$ \\
$\gamma$ & $90^{\circ}$ & $97.757(2)^{\circ}$ \\
Volume / A & $3399.0(4)$ & $5483.3(2)$ \\
$Z$ & 4 & 2 \\
Density (calcd.) & $1.771 \mathrm{~g} \cdot \mathrm{cm}^{-3}$ & $1.693 \mathrm{~g} \cdot \mathrm{cm}^{-3}$ \\
Completeness & 0.999 & 0.960 \\
Goodness-of-fit & 1.074 & 1.096 \\
$R_{1}(I>2 \sigma(I))$ & 0.0887 & 0.0556 \\
$w R_{2}($ all data $)$ & 0.2245 & 0.1643 \\
CCDC No. & 2052329 & 2052328 \\
\hline & &
\end{tabular}




\section{Cyclic voltammetry}

Potentials /V vs. $\mathrm{Fc} / \mathrm{Fc}^{+}$by cyclic voltammetry.

Working electrode: glassy carbon. Supporting electrolyte: $0.1 \mathrm{M} \mathrm{Bu}_{4} \mathrm{NPF}_{6}$ in $\mathrm{CH}_{2} \mathrm{Cl}_{2}$. Counter electrode: $\mathrm{Pt}$ wire. Reference electrode: $\mathrm{Ag} / \mathrm{AgNO}_{3}$. Scan rate: $0.05 \mathrm{~V} / \mathrm{s}$.

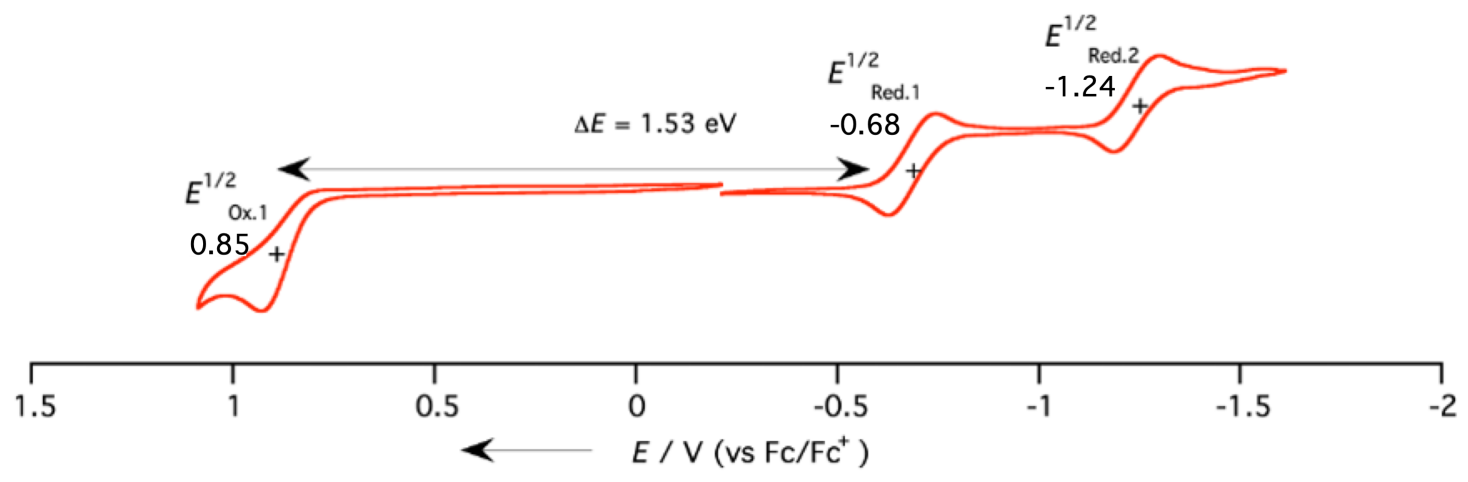

Figure S 6-1. Cyclic voltammogram of 4.



Figure S 6-2. Cyclic voltammogram of $\mathbf{4 N i}$. 




Figure S 6-3. Cyclic voltammogram of $\mathbf{4 P d}$.
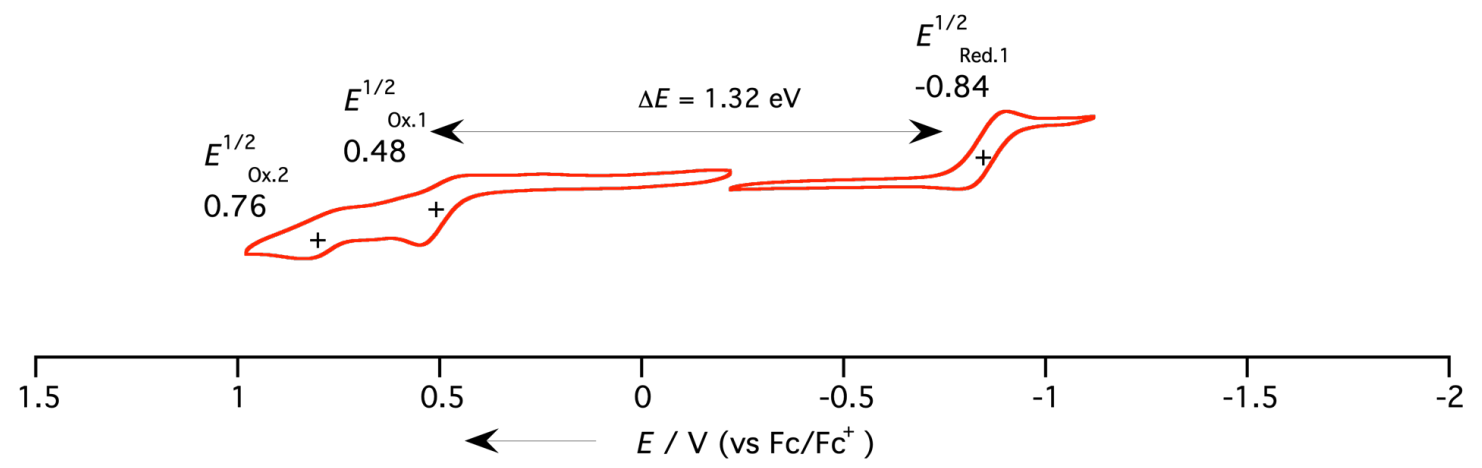

Figure S 6-4. Cyclic voltammogram of $4 \mathrm{ZnPy}$.

*Supporting electrolyte: $0.1 \mathrm{M} \mathrm{Bu}_{4} \mathrm{NPF}_{6}$ in $\mathrm{CH}_{2} \mathrm{Cl}_{2}$.

potentials/V vs. $\mathrm{Fc}^{+} / \mathrm{Fc}$ by cyclic voltammetry. Working electrode: glassy carbon. Counter electrode: $\mathrm{Pt}$ wire. Reference electrode: $\mathrm{Ag} / \mathrm{AgNO}$. Scan rate: $0.05 \mathrm{~V} / \mathrm{s}$. 


\section{DFT Calculations}





calcd. at B3LYP/6-311G(d,p) level.

Figure $S$ 7-1. MO diagrams for $1,4,4 \mathrm{ZnPy}, 4 \mathbf{P d}$, and $4 \mathrm{Ni}$ calculated at the B3LYP/6-311G(d,p) (for C,H,N,O,Zn,Ni) + SDD (for Pd) level of theory.



Figure $S$ 7-2. MO diagrams for $4,4 \mathrm{ZnPy}, 4 \mathrm{Pd}$, and $4 \mathrm{Ni}$ calculated at the CAMB3LYP/6-311G(d,p) (for C,H,N,O,Zn,Ni) + SDD (for Pd) level of theory. 




\begin{tabular}{lrrrrrrrr} 
& A & B & C & D & E & \multicolumn{2}{l}{ F } & \multicolumn{2}{l}{ G } \\
\hline NICS(0) & -4.81 & -7.58 & -5.37 & -2.83 & 12.19 & 12.14 & 10.44 & 9.86 \\
NICS(1) & -6.57 & -6.72 & -4.54 & -5.17 & 7.91 & 8.08 & 7.36 & 6.51 \\
NICS(1) & -11.95 & -14.05 & -9.09 & -8.37 & 28.01 & 29.67 & 28.76 & 27.07
\end{tabular}

Figure S 7-3. NICS values of 4 .

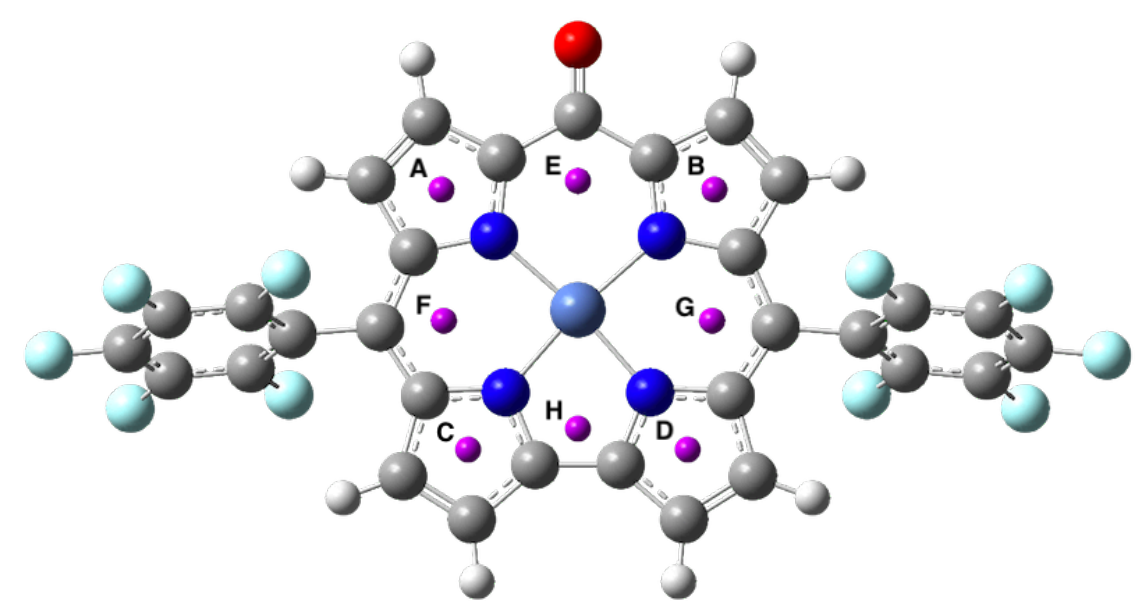

\begin{tabular}{lrrrrrrrr} 
& A & \multicolumn{1}{l}{ B } & \multicolumn{1}{l}{ C } & \multicolumn{1}{l}{ E } & \multicolumn{1}{l}{ F } & \multicolumn{2}{l}{ G } \\
\hline NICS(0) & -1.36 & -1.36 & -1.76 & -1.76 & 11.63 & 14.52 & 14.53 & 14.77 \\
NICS(1) & -3.69 & -3.70 & -3.50 & -3.50 & 9.50 & 12.13 & 12.13 & 13.69 \\
NICS(1) zz & -5.53 & -5.54 & -5.98 & -5.98 & 33.26 & 41.38 & 41.39 & 48.51
\end{tabular}

Figure S 7-4. NICS values of $4 \mathrm{Ni}$. 


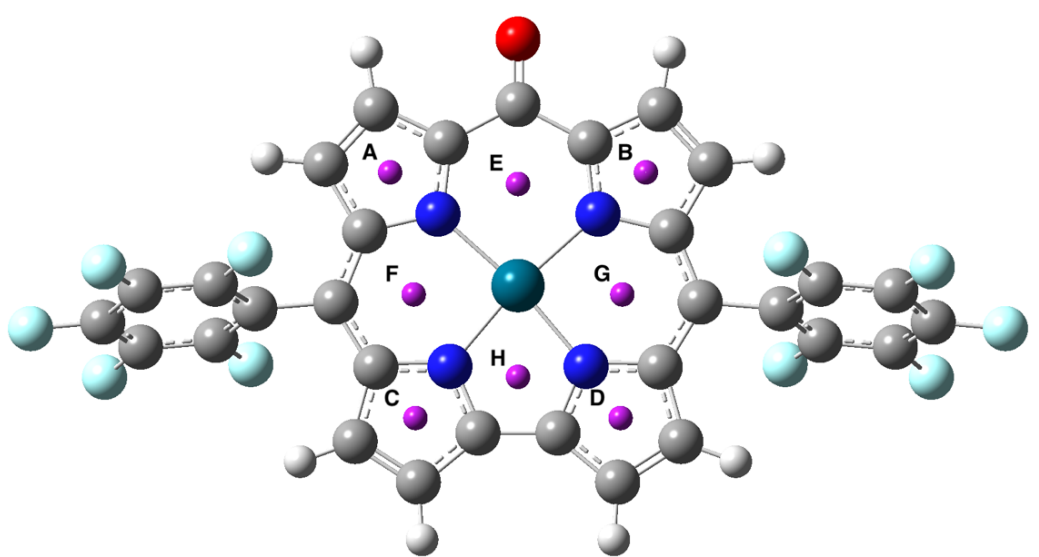

\begin{tabular}{lrrrrrrrr} 
& $\mathrm{A}$ & $\mathrm{B}$ & $\mathrm{C}$ & $\mathrm{D}$ & $\mathrm{E}$ & $\mathrm{F}$ & $\mathrm{G}$ & $\mathrm{H}$ \\
\hline $\mathrm{NICS}(0)$ & -0.51 & -0.51 & -2.33 & -2.33 & 10.91 & 14.68 & 14.68 & 17.82 \\
NICS(1) & -2.28 & -2.28 & -3.00 & -3.00 & 8.16 & 11.48 & 11.48 & 14.16 \\
NICS(1) & -1.47 & -1.47 & -4.68 & -4.68 & 30.30 & 41.08 & 41.08 & 51.19
\end{tabular}

Figure $S 7-5$. NICS values of 4 Pd.

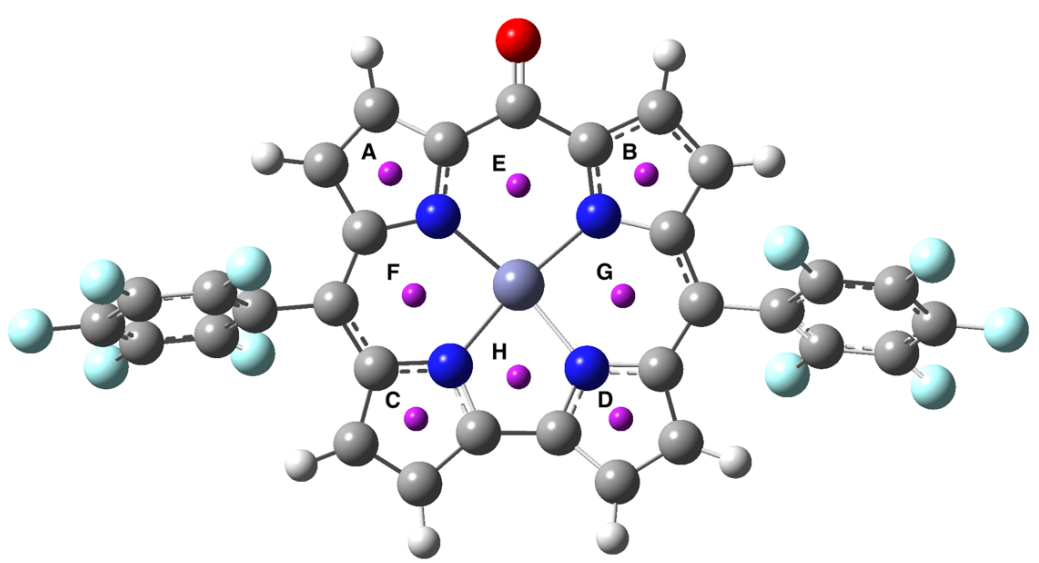

\begin{tabular}{lrrrrrrrr} 
& A & B & C & D & E & \multicolumn{1}{l}{ F } & \multicolumn{2}{l}{ G } \\
\hline NICS(0) & -6.01 & -6.07 & -3.77 & -3.69 & 13.04 & 13.06 & 12.81 & 10.48 \\
NICS(1) & -5.93 & -7.22 & -5.91 & -4.78 & 8.79 & 9.36 & 8.77 & 7.39 \\
NICS(1) zz & -11.11 & -14.48 & -11.04 & -8.42 & 31.41 & 33.70 & 33.11 & 30.43
\end{tabular}

Figure S 7-6. NICS values of $\mathbf{4 Z n}$. 




\begin{tabular}{lrrrrrrrr} 
& A & \multicolumn{1}{l}{ B } & \multicolumn{1}{l}{ C } & D & E & \multicolumn{1}{l}{ F } & \multicolumn{1}{l}{ G } \\
\hline NICS(0) & -6.25 & -6.25 & -3.79 & -3.79 & 13.99 & 13.93 & 13.93 & 12.27 \\
NICS(1) & -6.62 & -6.63 & -4.63 & -4.63 & 10.10 & 9.74 & 9.74 & 8.99 \\
NICS(1) & -14.50 & -14.51 & -9.59 & -9.59 & 34.42 & 34.03 & 34.03 & 33.22
\end{tabular}

Figure $S$ 7-7. NICS values of 4 ZnPy.

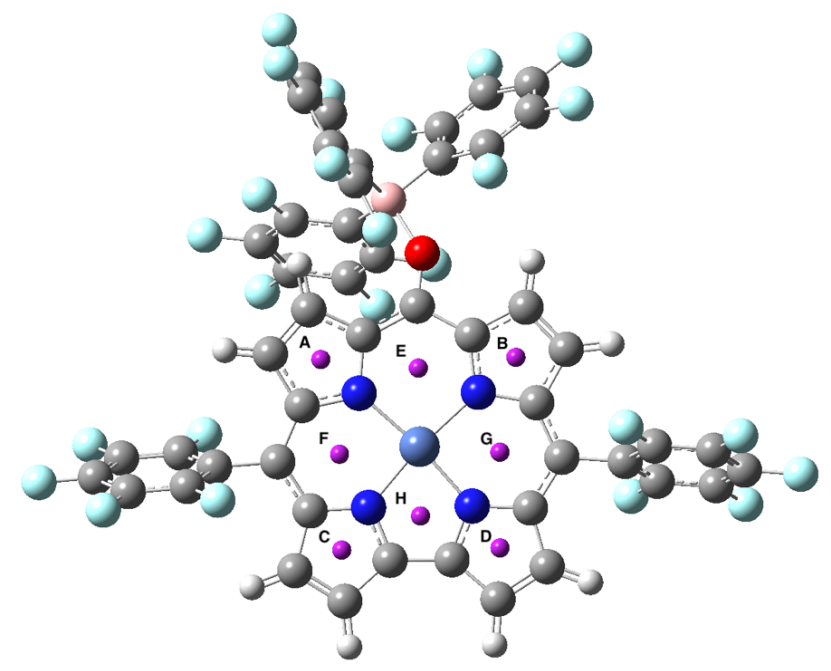

\begin{tabular}{lrrrrrrrr} 
& A & \multicolumn{1}{c}{ B } & \multicolumn{2}{c}{ C } & D & E & \multicolumn{1}{l}{ F } & \multicolumn{1}{l}{ G } \\
\hline NICS(0) & 2.73 & 4.00 & 2.15 & 1.70 & 30.84 & 37.06 & 37.62 & 40.04 \\
NICS(1) & 1.85 & 1.87 & 0.23 & 0.28 & 26.59 & 31.59 & 31.84 & 34.49 \\
NICS(1) zz & 8.32 & 10.96 & 6.24 & 5.30 & 87.19 & 99.52 & 100.37 & 112.09
\end{tabular}

Figure $S 7-8$. NICS values of $4 \mathbf{N i} \cdot \mathrm{B}\left(\mathrm{C}_{6} \mathrm{~F}_{5}\right)_{3}$. 


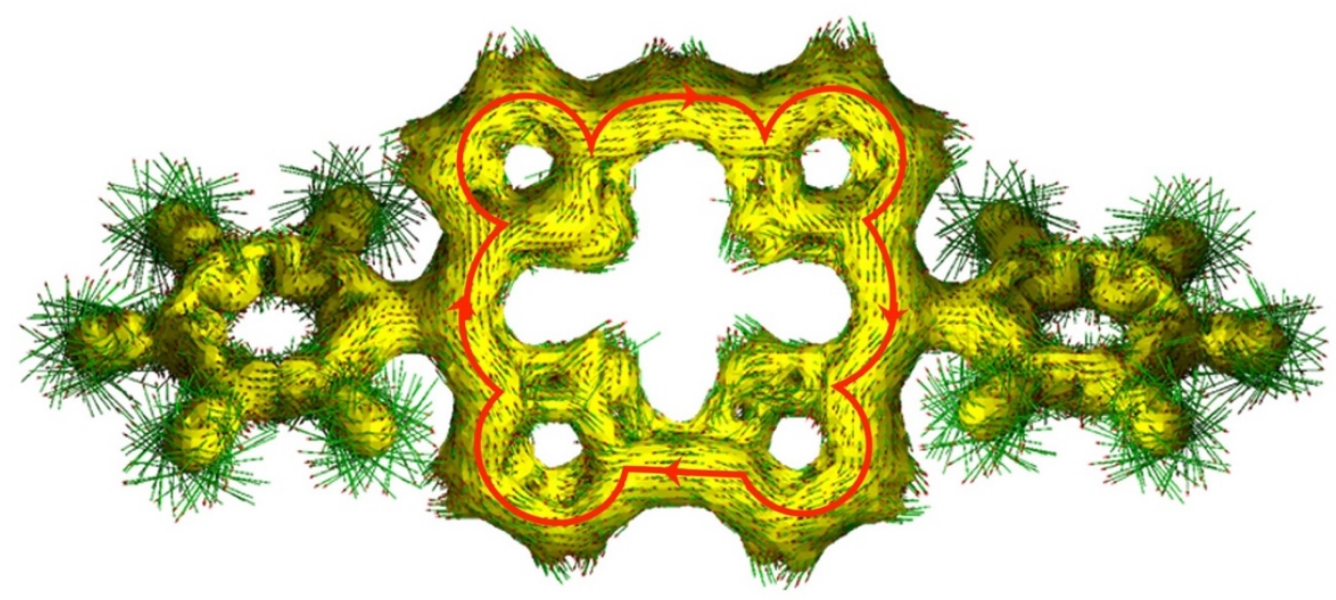

Figure S 7-9. ACID plot for 1 (isovalue = 0.05). The magnetic field is aligned perpendicular to the molecular plane and directed out of the image. The clockwise induced ring current in the corrole ring (red arrows) indicates aromaticity.

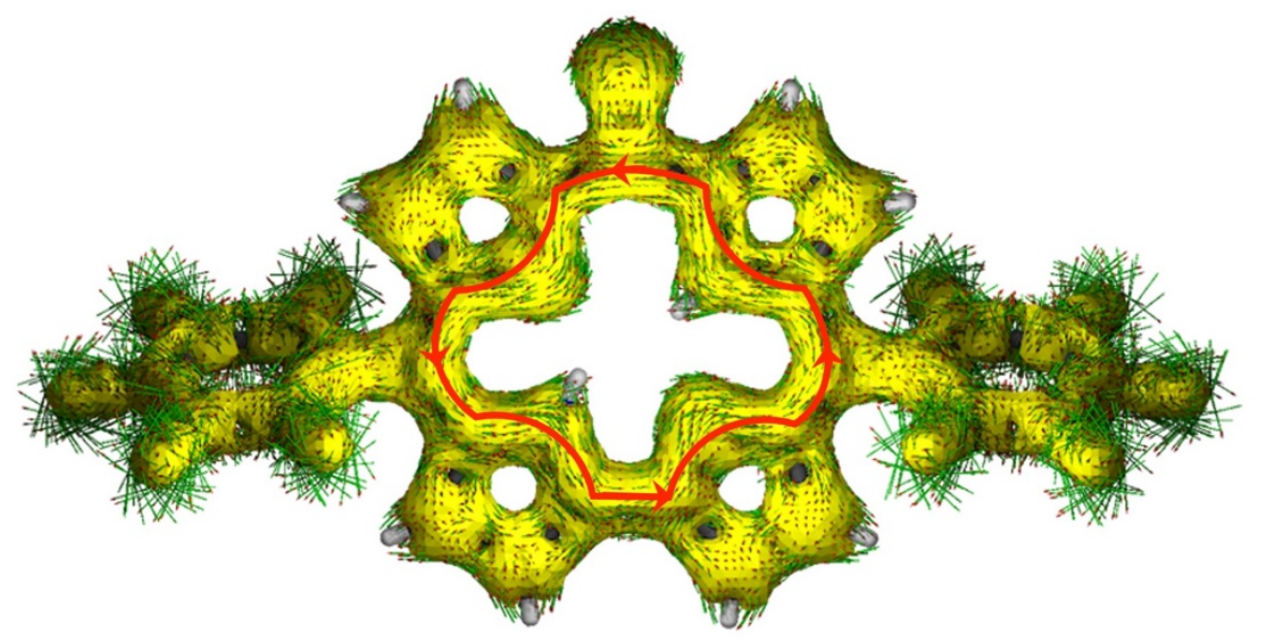

Figure S 7-10. ACID plot for 4 (isovalue =0.05). The magnetic field is aligned perpendicular to the molecular plane and directed out of the image. The counterclockwise induced ring current in the corrole ring (red arrows) indicates antiaromaticity. 


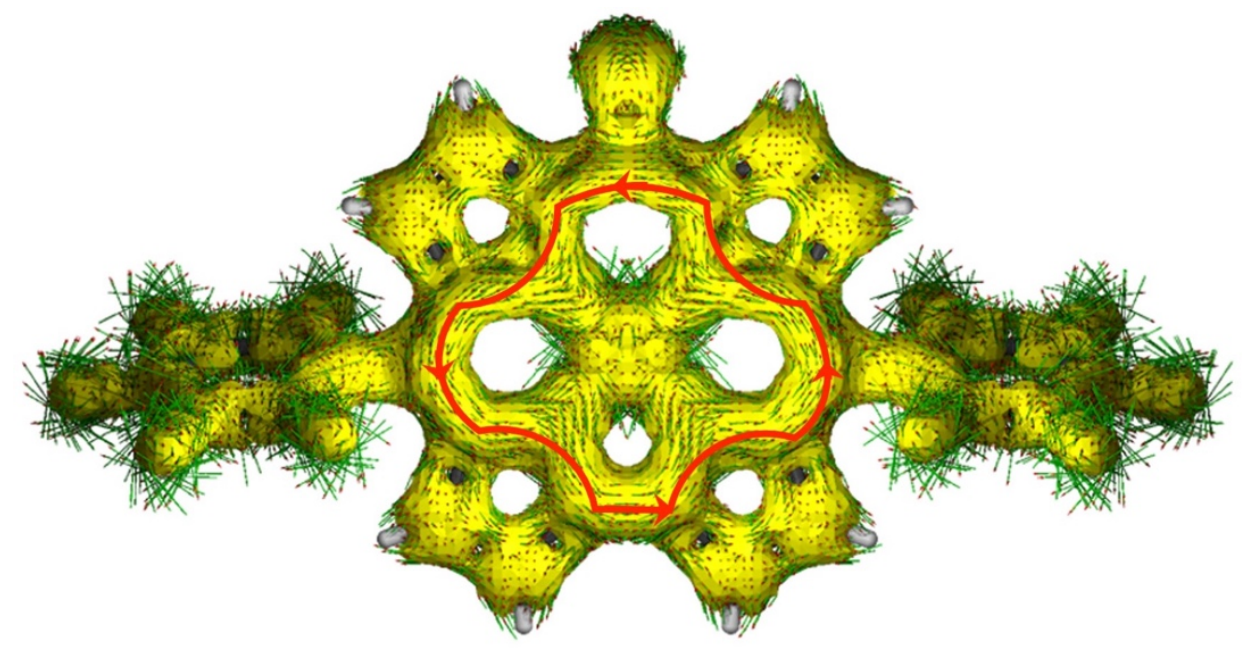

Figure $S$ 7-11. ACID plot for $4 \mathbf{N i}$ (isovalue $=0.05$ ). The magnetic field is aligned perpendicular to the molecular plane and directed out of the image. The counterclockwise induced ring current in the corrole ring (red arrows) indicates antiaromaticity.

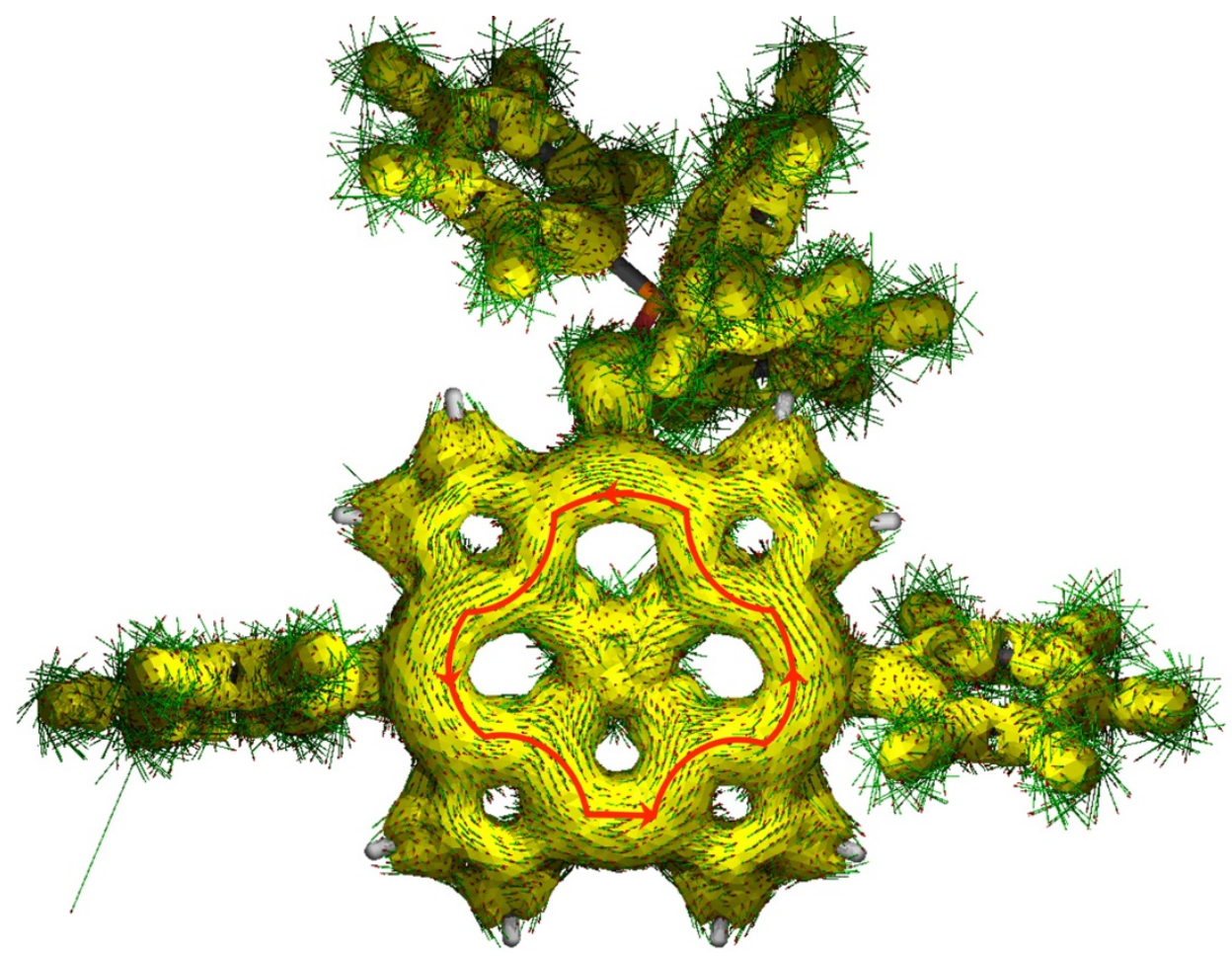

Figure $S$ 7-12. ACID plot for $4 \mathrm{Ni} \cdot \mathrm{B}\left(\mathrm{C}_{6} \mathrm{~F}_{5}\right)_{3}$ (isovalue $\left.=0.05\right)$. The magnetic field is aligned perpendicular to the molecular plane and directed out of the image. The counter-clockwise induced ring current (red arrows) indicates antiaromaticity. 


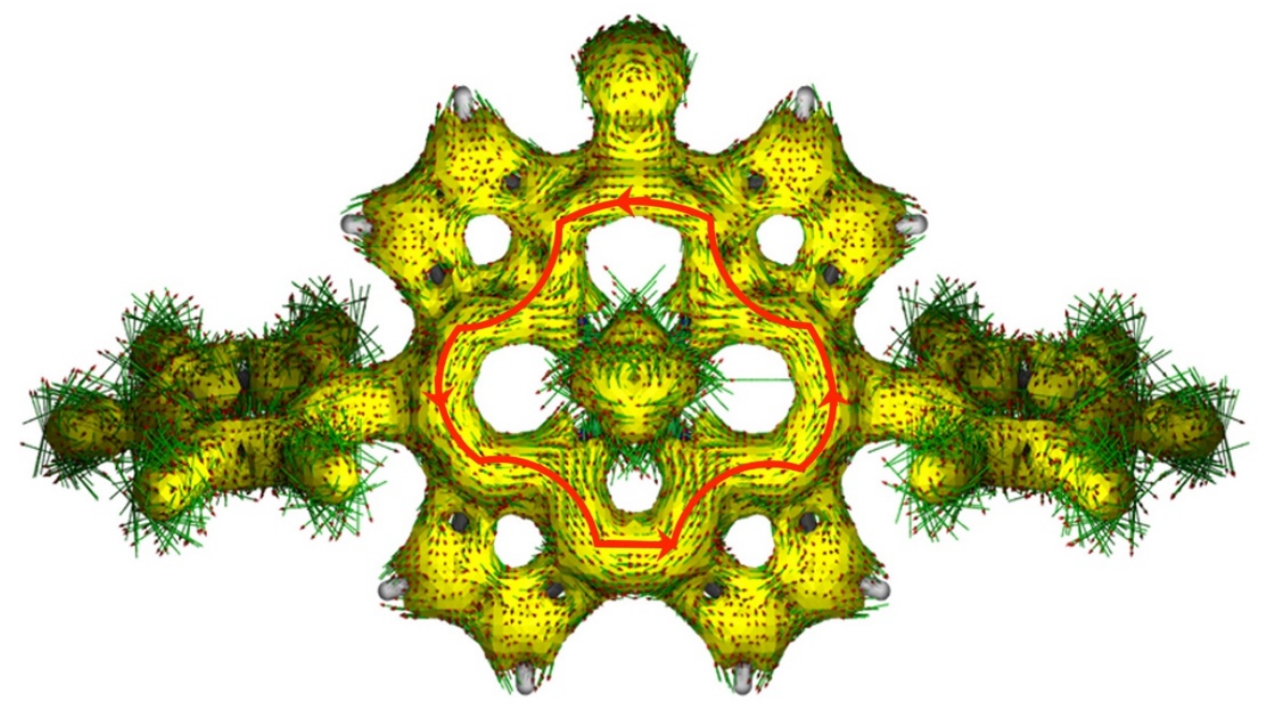

Figure S 7-13. ACID plot for $\mathbf{4 P d}$ (isovalue $=0.05$ ). The magnetic field is aligned perpendicular to the molecular plane and directed out of the image. The counterclockwise induced ring current in the corrole ring (red arrows) indicates antiaromaticity.



Figure S 7-14. ACID plot for $4 \mathrm{ZnPy}$ (isovalue =0.05). The magnetic field is aligned perpendicular to the molecular plane and directed out of the image. The counterclockwise induced ring current in the corrole ring (red arrows) indicates antiaromaticity. 


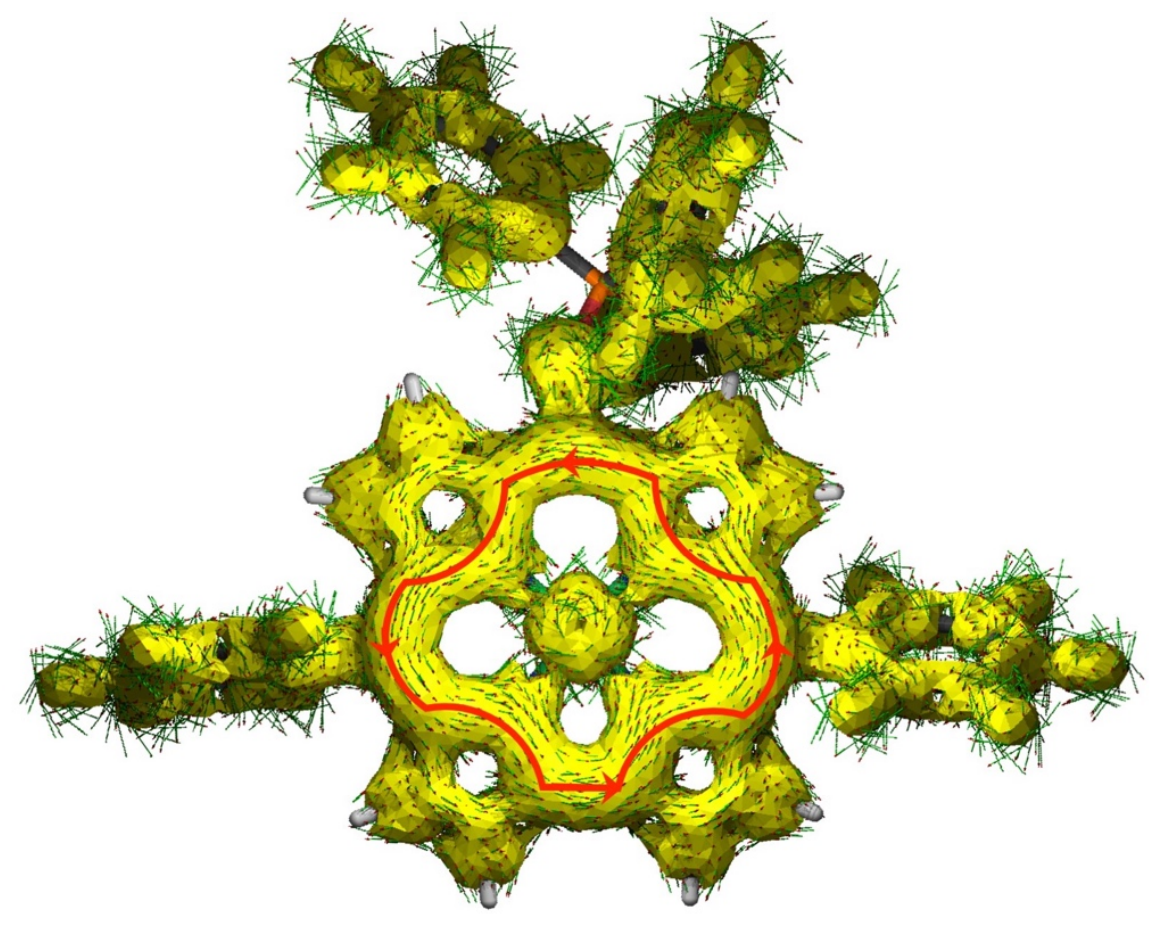

Figure $S$ 7-15. ACID plot for $4 \mathbf{P d} \cdot \mathrm{B}\left(\mathrm{C}_{6} \mathrm{~F}_{5}\right)_{3}$ (isovalue $\left.=0.05\right)$. The magnetic field is aligned perpendicular to the molecular plane and directed out of the image. The counter-clockwise induced ring current (red arrows) indicates antiaromaticity.

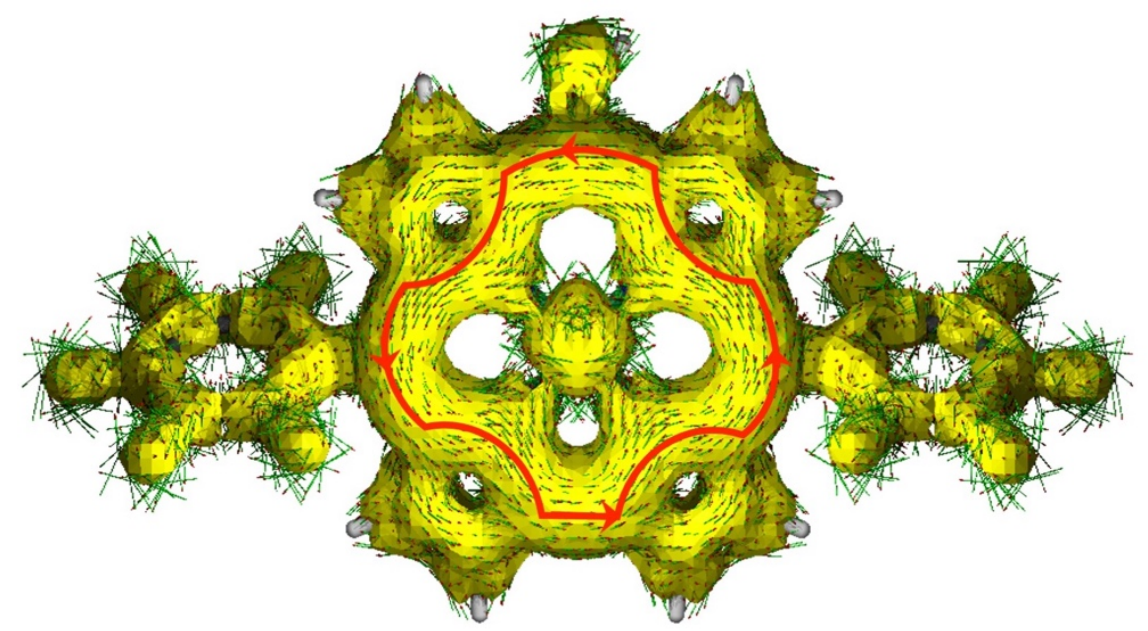

Figure S 7-16. ACID plot for $\mathbf{4} \mathbf{P d H}^{+}$(isovalue = 0.05). The magnetic field is aligned perpendicular to the molecular plane and directed out of the image. The counterclockwise induced ring current (red arrows) indicates antiaromaticity. 


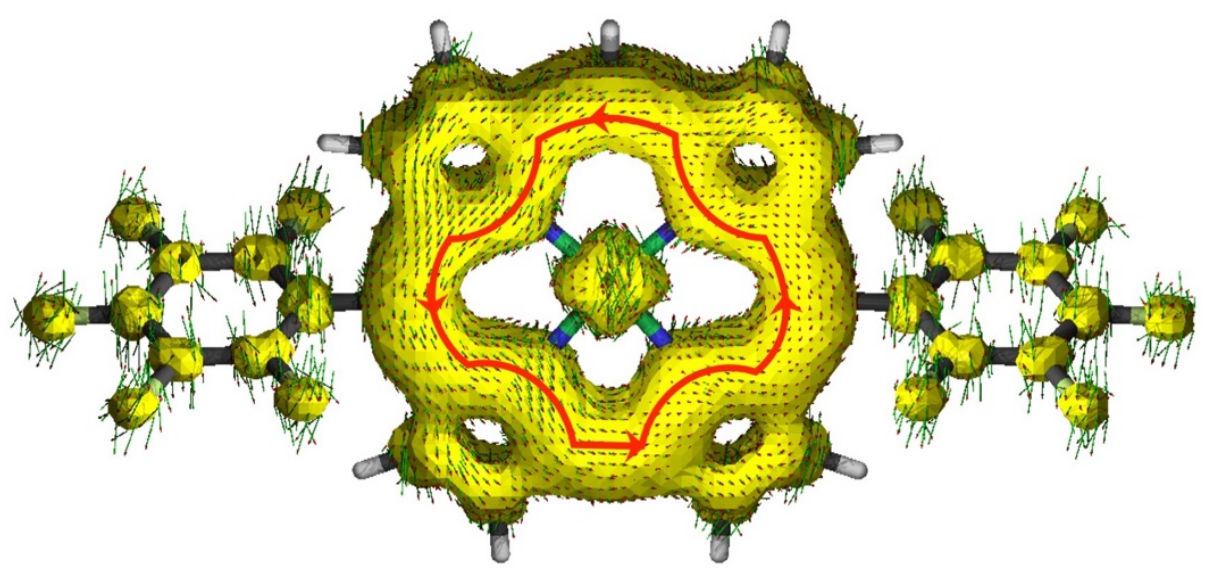

Figure S 7-17. ACID plot for $\mathbf{1} \mathbf{P d}^{+}$(isovalue $=0.10$ ). The magnetic field is aligned perpendicular to the molecular plane and directed out of the image. The counterclockwise induced ring current (red arrows) indicates antiaromaticity.

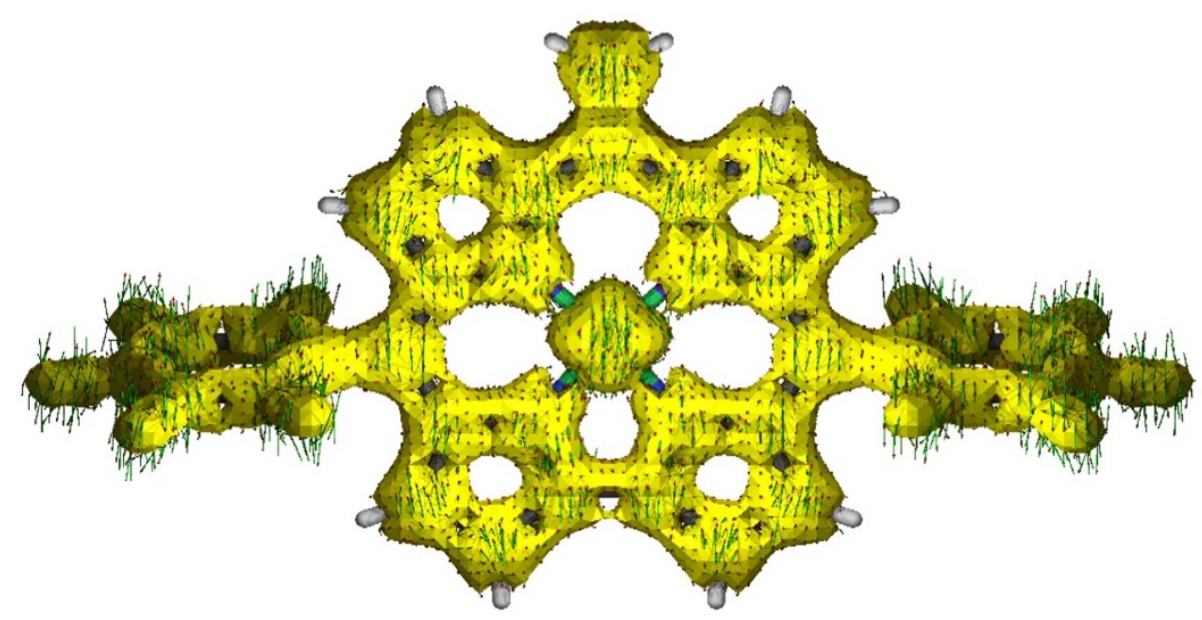

Figure S 7-18. ACID plot for 5Pd (isovalue $=0.05$ ). The magnetic field is aligned perpendicular to the molecular plane and directed out of the image. 


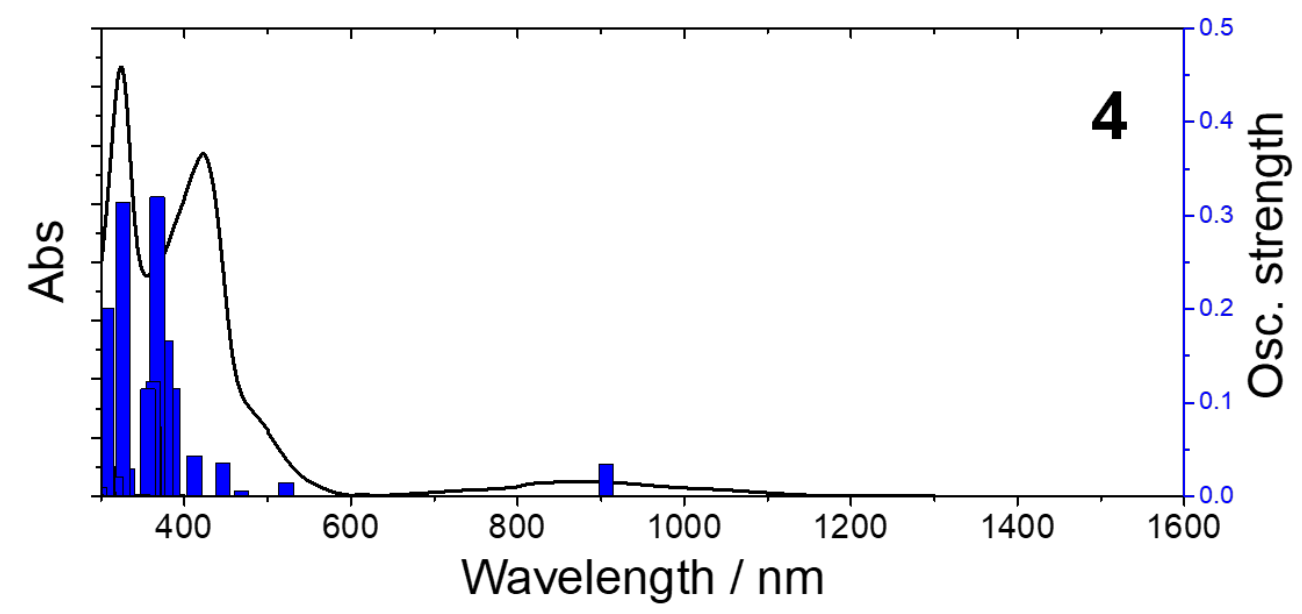

\begin{tabular}{|c|c|c|c|}
\hline No. & Wavelength $(\mathrm{nm})$ & Osc. Strength & Major contribs \\
\hline 1 & 906.3 & 0.0345 & HOMO->LUMO (100\%) \\
\hline 2 & 522.1 & 0.0143 & H-1->LUMO (66\%), HOMO->L+1 (30\%) \\
\hline 3 & 479.3 & 0.0010 & H-4->LUMO (89\%) \\
\hline 4 & 468.7 & 0.0049 & H-2->LUMO (90\%) \\
\hline 5 & 446.1 & 0.0353 & H-3->LUMO (62\%), HOMO->L+1 (21\%) \\
\hline 6 & 412.1 & 0.0433 & H-7->LUMO (10\%), H-6->LUMO (57\%), H-3->LUMO (14\%) \\
\hline 7 & 392.1 & 0.0011 & H-5->LUMO (94\%) \\
\hline 8 & 391.0 & 0.0012 & H-7->LUMO (84\%), H-6->LUMO (13\%) \\
\hline 9 & 386.1 & 0.1149 & H-9->LUMO (56\%), H-6->LUMO (12\%) \\
\hline 10 & 377.2 & 0.1663 & H-8->LUMO (67\%) \\
\hline
\end{tabular}

Figure $S$ 7-19. Vertical transitions of 4 based on the TD-DFT calculation results. Calculations were performed at B3LYP/6-31G(d,p) level. 


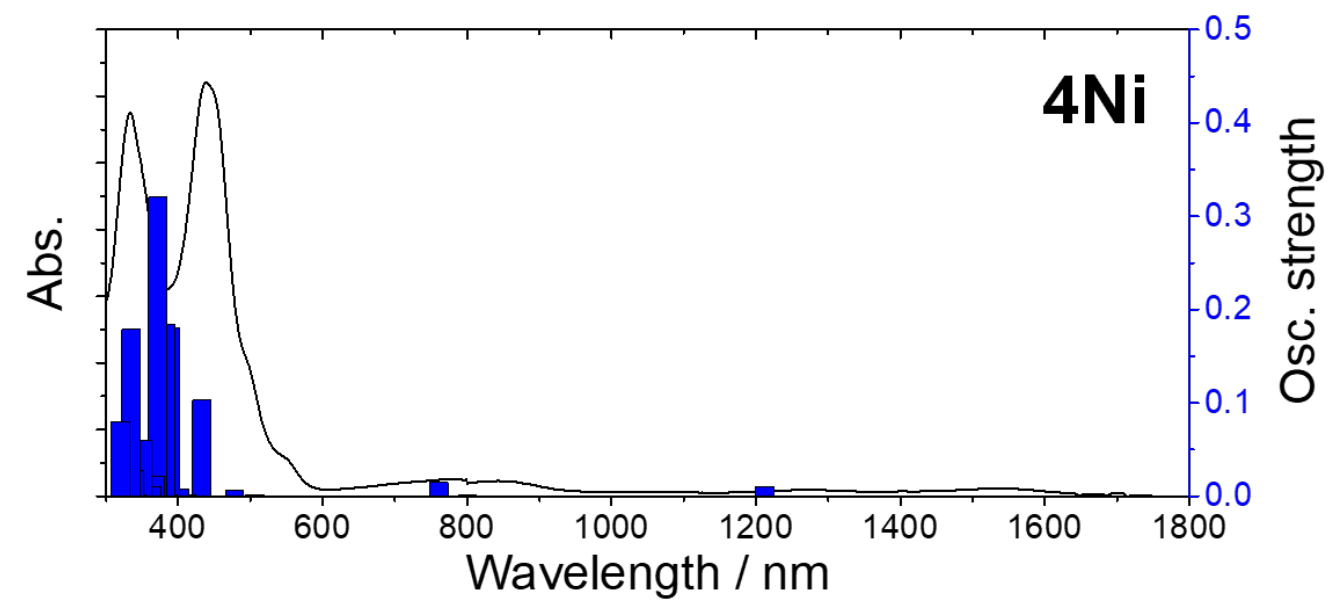

\begin{tabular}{cccl} 
No. & Wavelength $(\mathrm{nm})$ & Osc. Strength & Major contribs \\
\hline 1 & 1211.7298 & 0.0100 & $\mathrm{HOMO}->\mathrm{LUMO}(98 \%)$ \\
2 & 800.7246 & 0.0009 & $\mathrm{H}-1->\mathrm{LUMO}(96 \%)$ \\
3 & 760.7326 & 0.0149 & $\mathrm{H}-2->\mathrm{LUMO}(97 \%)$ \\
4 & 728.4190 & 0.0005 & $\mathrm{H}-3->\mathrm{LUMO}(100 \%)$ \\
5 & 538.6402 & 0.0000 & $\mathrm{H}-12->\mathrm{L}+4(11 \%), \mathrm{H}-2->\mathrm{L}+4(64 \%), \mathrm{HOMO}->\mathrm{L}+4(20 \%)$ \\
6 & 527.0988564 & 0.0001 & $\mathrm{H}-4->\mathrm{LUMO}(42 \%), \mathrm{HOMO}->\mathrm{L}+1(52 \%)$ \\
7 & 508.7783373 & 0.0007 & $\mathrm{H}-4->\mathrm{L}+4(10 \%), \mathrm{H}-3->\mathrm{L}+4(30 \%), \mathrm{H}-1->\mathrm{L}+4(44 \%)$ \\
8 & 506.9269483 & 0.0003 & $\mathrm{H}-3->\mathrm{L}+4(60 \%), \mathrm{H}-1->\mathrm{L}+4(21 \%)$ \\
9 & 505.8721001 & 0.0014 & $\mathrm{H}-6->\mathrm{LUMO}(83 \%)$ \\
10 & 477.8915858 & 0.0066 & $\mathrm{H}-5->$ LUMO $(92 \%)$ \\
\hline
\end{tabular}

Figure S 7-20. Vertical transitions of $4 \mathrm{Ni}$ based on the TD-DFT calculation results Calculations were performed at B3LYP/6-31G(d,p) level. 


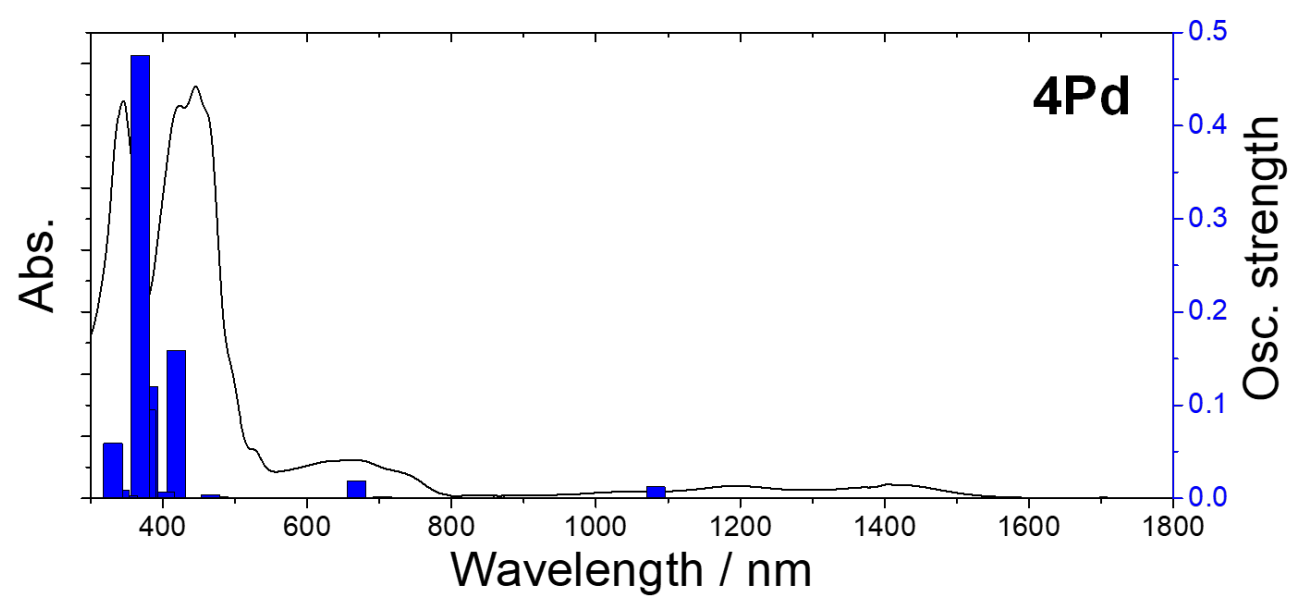

\begin{tabular}{cccl} 
No. & Wavelength $(\mathrm{nm})$ & Osc. Strength & Major contribs \\
\hline 1 & 1082.8 & 0.0123 & HOMO->LUMO $(99 \%)$ \\
2 & 703.8 & 0.0021 & H-1->LUMO $(95 \%)$ \\
3 & 668.2 & 0.0187 & H-2->LUMO $(98 \%)$ \\
4 & 573.9 & 0.0006 & H-4->LUMO $(100 \%)$ \\
5 & 516.3 & 0.0003 & H-3->LUMO $(40 \%)$, HOMO->L+1 (56\%) \\
6 & 477.7 & 0.0013 & H-8->LUMO $(85 \%)$ \\
7 & 465.4 & 0.0042 & H-5->LUMO $(95 \%)$ \\
8 & 418.4 & 0.1585 & H-3->LUMO $(26 \%)$, H-2->L+1 (50\%) \\
9 & 413.1 & 0.0000 & H-1->L+1 $(91 \%)$ \\
10 & 406.4 & 0.0009 & H-9->LUMO $(13 \%)$, H-6->LUMO (85\%) \\
\hline
\end{tabular}

Figure $S$ 7-21. Vertical transitions of $4 \mathbf{P d}$ based on the TD-DFT calculation results. Calculations were performed at B3LYP/6-31G(d,p) + SDD (for Pd atom) level. 


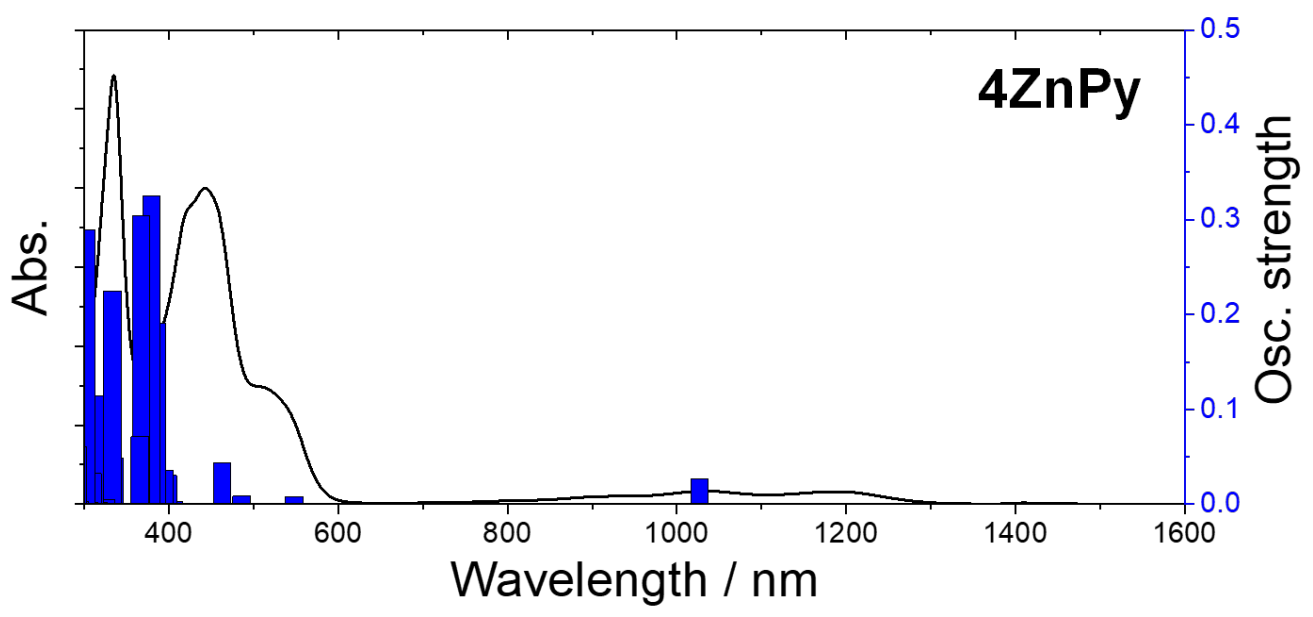

\begin{tabular}{cccl} 
No. & Wavelength $(\mathrm{nm})$ & Osc. Strength & Major contribs \\
\hline 1 & 1026.8 & 0.0268 & HOMO->LUMO $(100 \%)$ \\
2 & 630.3 & 0.0002 & H-2->LUMO $(98 \%)$ \\
3 & 547.8 & 0.0084 & H-1->LUMO $(70 \%)$, HOMO->L+1 $(27 \%)$ \\
4 & 489.0 & 0.0006 & H-6->LUMO $(53 \%)$, H-4->LUMO (34\%) \\
5 & 485.7 & 0.0086 & H-3->LUMO $(92 \%)$ \\
6 & 465.6 & 0.0001 & H-6->LUMO $(30 \%)$, H-4->LUMO $(61 \%)$ \\
7 & 463.0 & 0.0437 & H-5->LUMO $(63 \%)$, HOMO->L+1 $(31 \%)$ \\
8 & 405.5 & 0.0028 & H-7->LUMO $(97 \%)$ \\
9 & 405.5 & 0.0001 & H-8->LUMO $(93 \%)$ \\
10 & 398.5 & 0.0306 & H-9->LUMO (89\%) \\
\hline
\end{tabular}

Figure $S$ 7-22. Vertical transitions of $4 \mathrm{ZnPy}$ based on the TD-DFT calculation results. Calculations were performed at B3LYP/6-31G(d,p) level. 
Table S 7-1. Comparison of the NICS(0) values of $4,4 \mathbf{N i}, 4 \mathbf{N i} \cdot \mathbf{B}\left(\mathbf{C}_{6} \mathbf{F}_{5}\right)_{3}, \mathbf{Z Z n P y}, 4 \mathbf{P d}$, $4 \mathbf{P d} \cdot \mathbf{B}\left(\mathrm{C}_{6} \mathrm{~F}_{5}\right)_{3}, 4 \mathbf{P d H}^{+}, \mathbf{P d}^{+}$and $5 \mathbf{P d}\left(\mathrm{S}_{0}\right.$ state) at two different level of theory, B3LYP/6-311G(d,p) and CAM-B3LYP/6-311G(d,p).

\begin{tabular}{|c|c|c|c|c|c|c|}
\hline So-state & Basis set & $A, B$ & $C, D$ & $\mathrm{E}$ & $F, G$ & $\mathrm{H}$ \\
\hline \multirow[t]{4}{*}{4} & B3LYP & -4.81 & -5.37 & 12.19 & 12.14 & 9.84 \\
\hline & & -7.58 & -2.83 & & 10.44 & \\
\hline & CAM-B3LYP & -4.50 & -6.92 & 10.06 & 10.05 & 7.74 \\
\hline & & -8.90 & -2.63 & & 9.72 & \\
\hline \multirow[t]{2}{*}{$4 \mathrm{Ni}$} & B3LYP & -1.36 & -1.76 & 11.63 & 14.53 & 14.77 \\
\hline & CAM-B3LYP & -2.82 & -2.74 & 8.55 & 10.54 & 9.87 \\
\hline \multirow[t]{4}{*}{$4 \mathrm{Ni} \cdot \mathrm{B}\left(\mathrm{C}_{6} \mathrm{~F}_{5}\right)_{3}$} & B3LYP & 2.73 & 2.15 & 30.84 & 37.06 & 40.04 \\
\hline & & 4.00 & 1.70 & & 37.62 & \\
\hline & CAM-B3LYP & -1.62 & -1.22 & 19.82 & 23.45 & 24.39 \\
\hline & & 0.88 & 0.71 & & 24.33 & \\
\hline \multirow[t]{2}{*}{ 4ZnPy } & B3LYP & -6.25 & -3.79 & 13.99 & 13.93 & 12.27 \\
\hline & CAM-B3LYP & -6.88 & -4.35 & 11.27 & 11.29 & 9.42 \\
\hline \multirow[t]{2}{*}{$4 \mathrm{Pd}$} & B3LYP & -0.51 & -2.33 & 10.91 & 14.68 & 17.82 \\
\hline & CAM-B3LYP & -2.25 & -3.33 & 8.37 & 10.97 & 13.11 \\
\hline \multirow[t]{4}{*}{$4 \mathrm{Pd} \cdot \mathrm{B}\left(\mathrm{C}_{6} \mathrm{~F}_{5}\right)_{3}$} & B3LYP & 1.85 & 0.51 & 26.87 & 34.06 & 39.84 \\
\hline & & 3.26 & 0.05 & & 34.36 & \\
\hline & CAM-B3LYP & -2.09 & -2.15 & 18.16 & 22.51 & 26.32 \\
\hline & & 0.61 & -0.29 & & 23.26 & \\
\hline \multirow[t]{4}{*}{$4 \mathrm{PdH}^{+}$} & B3LYP & 2.32 & 0.92 & 37.68 & 45.23 & 52.90 \\
\hline & & 3.61 & 1.94 & & 46.56 & \\
\hline & CAM-B3LYP & -0.97 & 0.13 & 24.14 & 29.01 & 33.50 \\
\hline & & 0.01 & -0.13 & & 29.83 & \\
\hline \multirow[t]{2}{*}{$1 \mathbf{P d}^{+}$} & B3LYP & 12.75 & 4.03 & 75.25 & 84.95 & 95.20 \\
\hline & CAM-B3LYP & 5.78 & 1.62 & 44.27 & 49.22 & 54.62 \\
\hline \multirow[t]{2}{*}{$5 P d$} & B3LYP & -3.05 & -4.89 & -3.69 & -0.05 & 1.89 \\
\hline & CAM-B3LYP & -3.37 & -5.48 & -3.26 & 0.01 & 1.49 \\
\hline
\end{tabular}


Table $S$ 7-2. Comparison of the NICS(0) values of $4,4 \mathbf{N i}, 4 \mathbf{N i} \cdot \mathbf{B}\left(\mathbf{C}_{6} \mathbf{F}_{5}\right)_{3}, \mathbf{4 Z n P y}, 4 \mathbf{P d}$, $4 \mathbf{P d} \cdot \mathbf{B}\left(\mathbf{C}_{6} \mathbf{F}_{5}\right)_{3}, 4 \mathbf{P d H} \mathbf{H}^{+}, \mathbf{P P d}{ }^{+}$and $5 \mathbf{P d}$ (T1-state) at two different levels of theory, B3LYP/6-311G(d,p) and CAM-B3LYP/6-311G(d,p).

\begin{tabular}{|c|c|c|c|c|c|c|}
\hline T1-state & Basis set & A, B & C, D & $\mathrm{E}$ & $F, G$ & $\mathrm{H}$ \\
\hline \multirow[t]{4}{*}{4} & B3LYP & -6.73 & -1.97 & -2.03 & -5.39 & -11.7 \\
\hline & & 1.16 & -7.08 & & -5.29 & \\
\hline & CAM-B3LYP & -7.13 & -1.35 & -0.08 & -4.14 & -10.28 \\
\hline & & -0.27 & -6.68 & & -3.32 & \\
\hline \multirow[t]{2}{*}{$4 \mathrm{Ni}$} & B3LYP & -3.96 & -3.51 & -5.01 & -8.05 & -9.86 \\
\hline & CAM-B3LYP & -3.43 & -3.20 & -6.05 & -7.65 & -10.78 \\
\hline \multirow[t]{4}{*}{$4 \mathrm{Ni} \cdot \mathrm{B}\left(\mathrm{C}_{6} \mathrm{~F}_{5}\right)_{3}$} & B3LYP & -5.19 & -3.14 & -9.43 & -12.78 & -15.64 \\
\hline & & -3.50 & -3.06 & & -12.72 & \\
\hline & CAM-B3LYP & -4.65 & -4.21 & -10.92 & -12.09 & -15.68 \\
\hline & & -3.01 & -3.78 & & -11.87 & \\
\hline \multirow[t]{2}{*}{ 4ZnPy } & B3LYP & -3.17 & -4.17 & -2.31 & -2.97 & -5.20 \\
\hline & CAM-B3LYP & -3.99 & -3.45 & -1.49 & -2.26 & -4.16 \\
\hline \multirow[t]{2}{*}{$4 P d$} & B3LYP & -4.34 & -2.63 & -2.93 & -6.20 & -7.40 \\
\hline & CAM-B3LYP & -3.77 & -2.31 & -3.51 & -6.01 & -7.54 \\
\hline \multirow[t]{4}{*}{$4 \mathrm{Pd} \cdot \mathrm{B}\left(\mathrm{C}_{6} \mathrm{~F}_{5}\right)_{3}$} & B3LYP & -5.00 & -2.54 & -7.33 & -10.61 & -12.94 \\
\hline & & -3.39 & -2.34 & & -10.45 & \\
\hline & CAM-B3LYP & -4.33 & -3.48 & -8.24 & -10.09 & -12.08 \\
\hline & & -2.87 & -3.28 & & -9.65 & \\
\hline \multirow[t]{4}{*}{$4 \mathrm{PdH}^{+}$} & B3LYP & -4.22 & -0.32 & -7.81 & -11.71 & -15.37 \\
\hline & & -3.33 & -0.51 & & -11.43 & \\
\hline & CAM-B3LYP & -4.68 & -2.13 & -9.24 & -11.66 & -15.30 \\
\hline & & -3.68 & -1.49 & & -11.41 & \\
\hline \multirow[t]{2}{*}{$1 \mathrm{Pd}^{+}$} & B3LYP & -0.23 & 1.77 & -7.90 & -13.15 & -18.06 \\
\hline & CAM-B3LYP & -0.09 & 0.64 & -10.40 & -14.01 & -18.50 \\
\hline \multirow[t]{2}{*}{$5 \mathrm{Pd}$} & B3LYP & -3.10 & -2.30 & 4.00 & 4.91 & 7.41 \\
\hline & CAM-B3LYP & -2.37 & -1.60 & 1.28 & 1.79 & 2.50 \\
\hline
\end{tabular}




\section{IR Spectra}



Figure S 8-1. IR (ATR) spectrum of 4 .

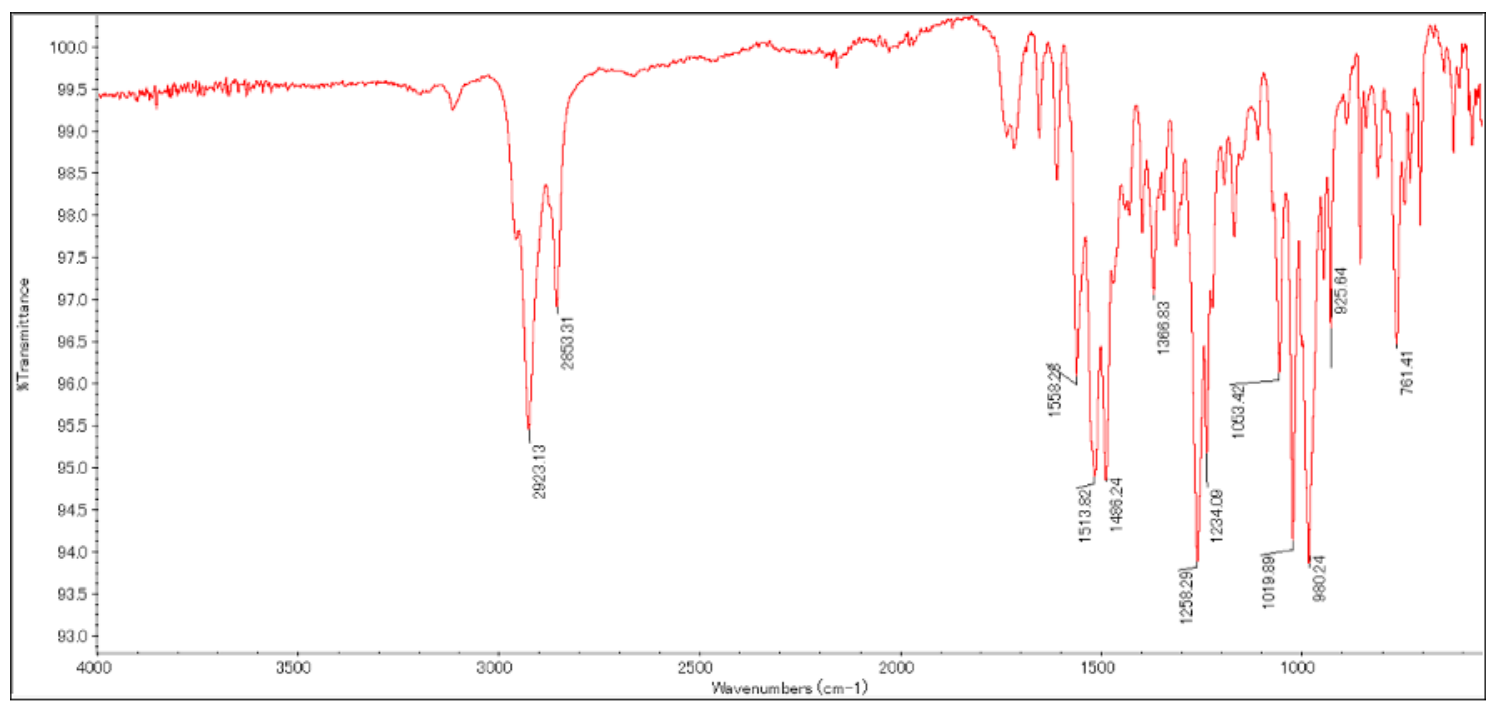

Figure $S$ 8-2. IR (ATR) spectrum of $\mathbf{4 N i}$. 




Figure $S$ 8-3. IR (ATR) spectrum of $\mathbf{4 P d}$.

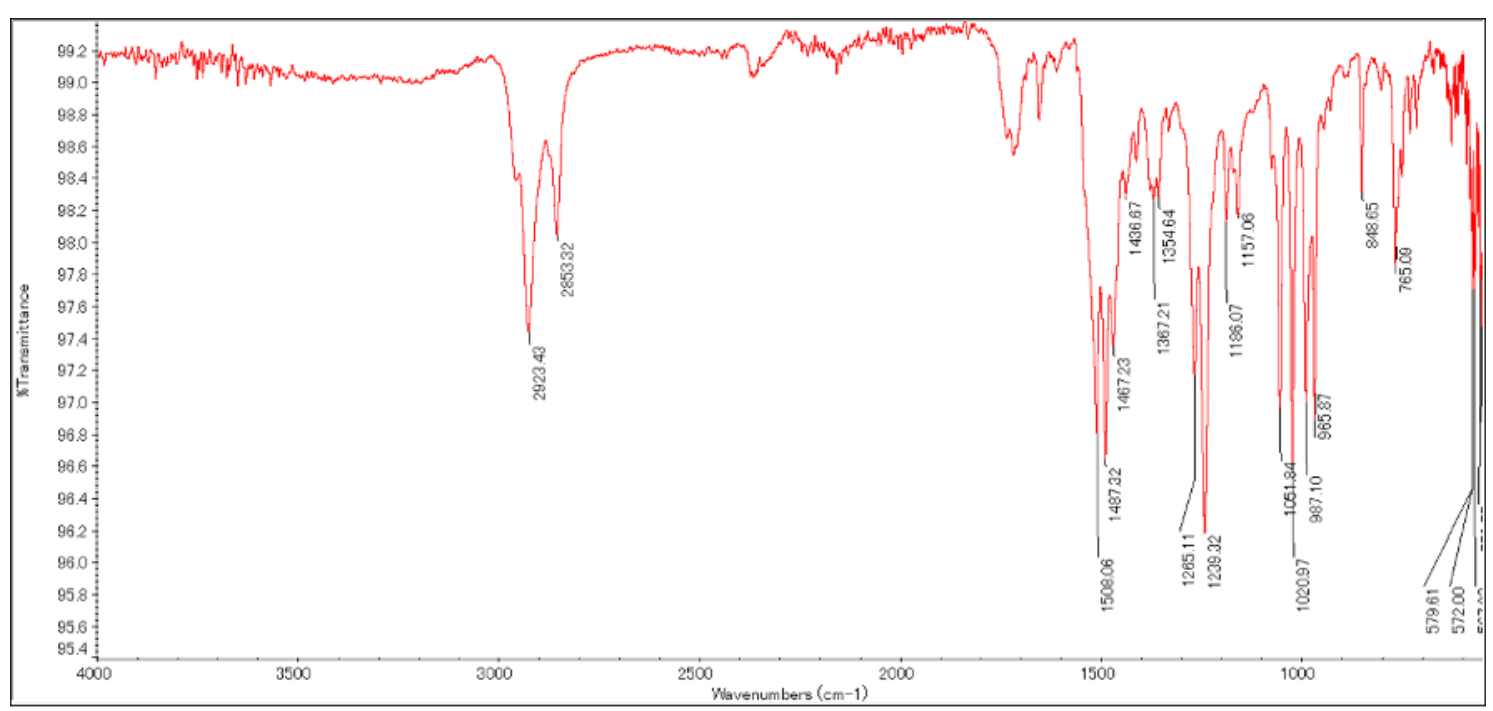

Figure S 8-4. IR (ATR) spectrum of 4 Zn. 


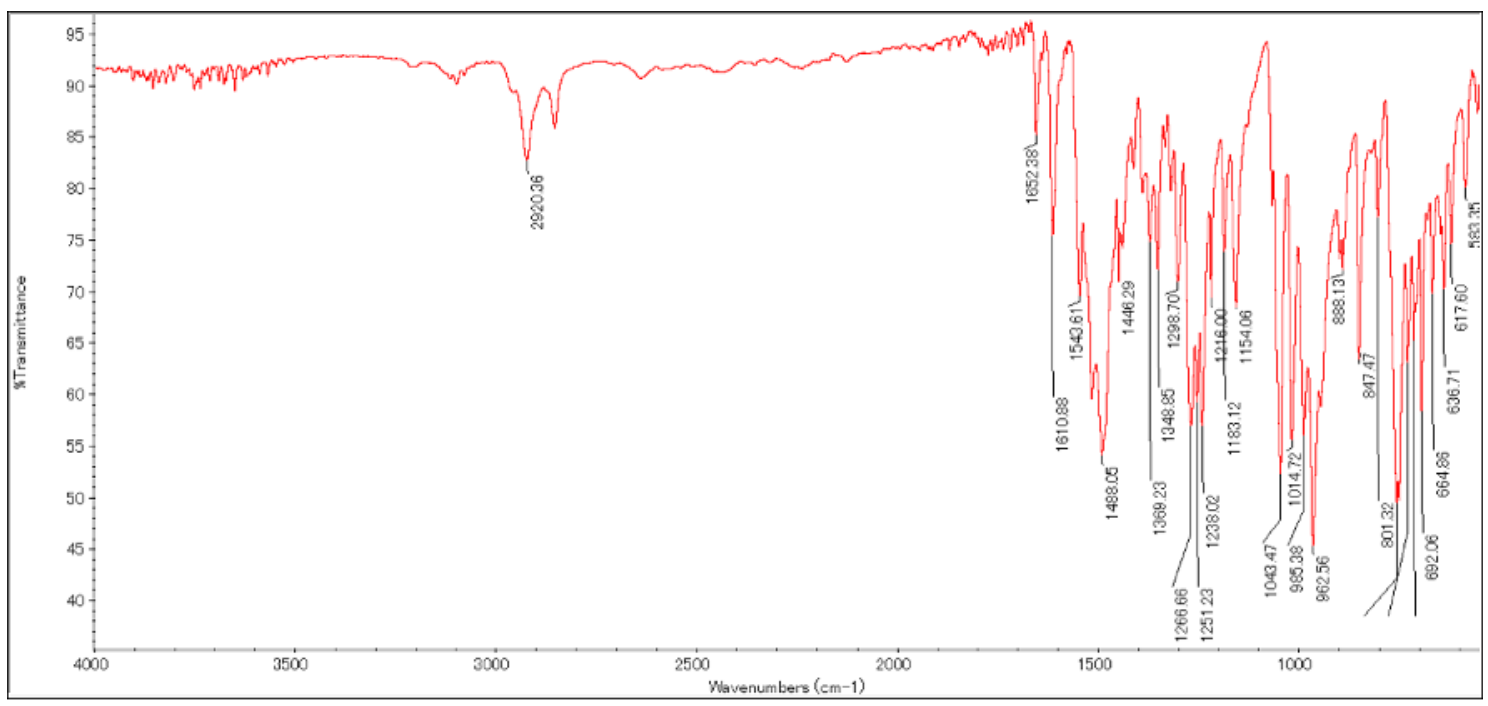

Figure $S$ 8-5. IR (ATR) spectrum of $\mathbf{4 Z n P y}$.

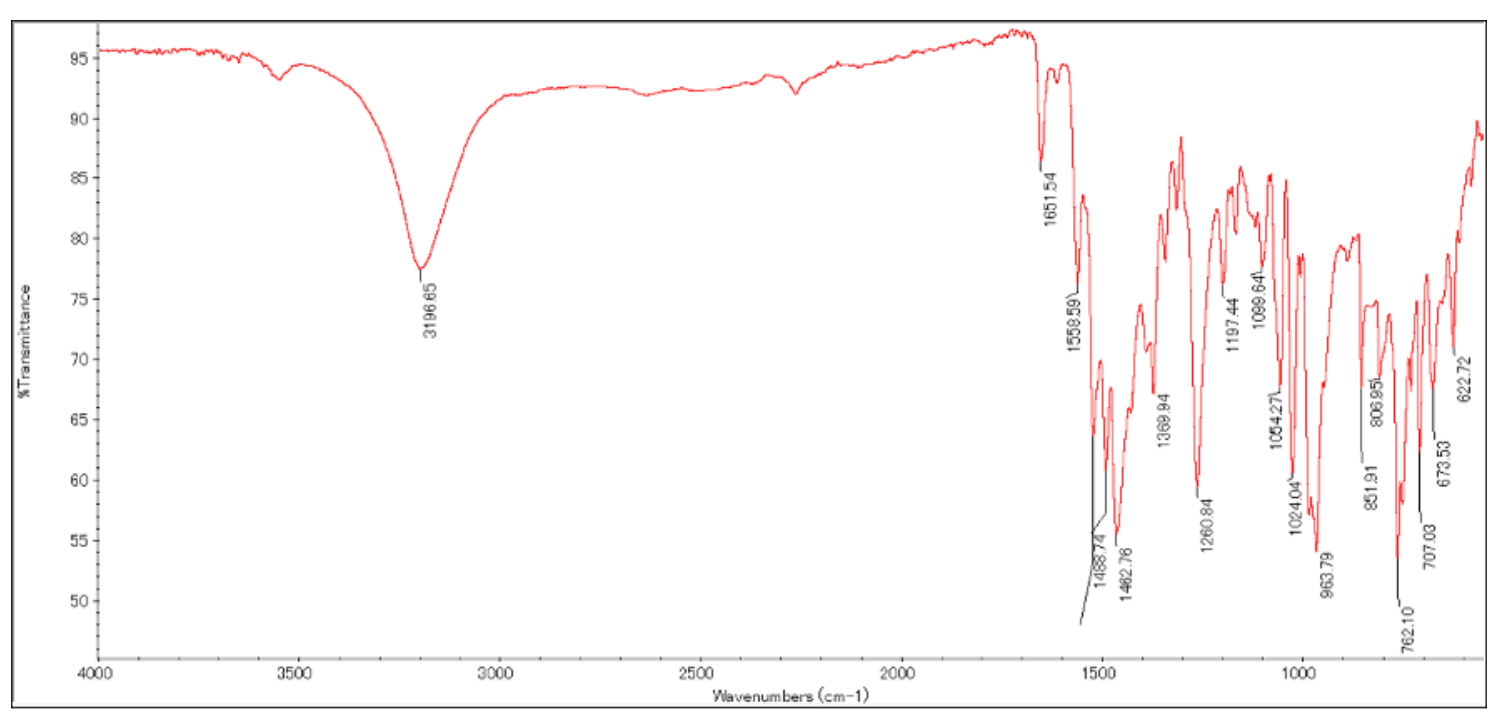

Figure $S$ 8-6. IR (ATR) spectrum of $4 \mathrm{Ni} \cdot \mathrm{B}\left(\mathrm{C}_{6} \mathrm{~F}_{5}\right)_{3}$. 


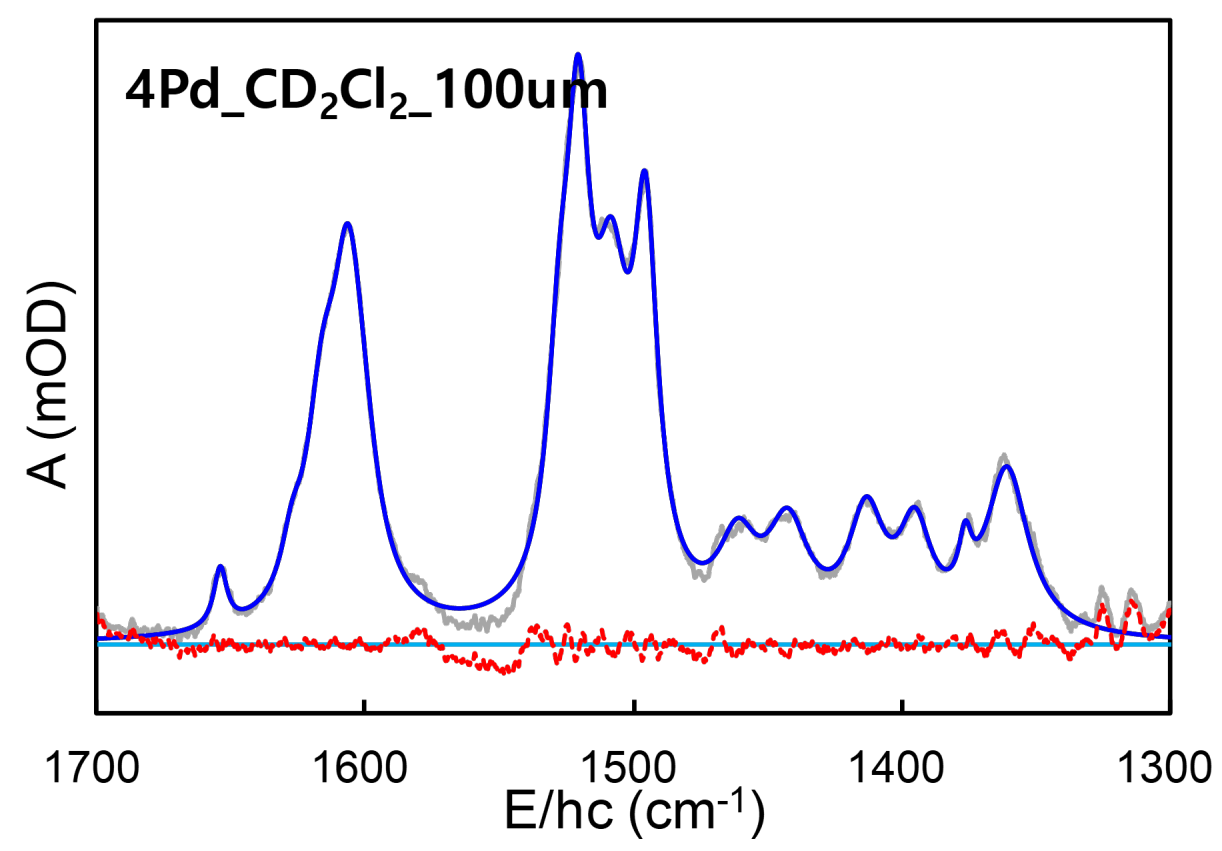

Figure S 8-7. The solution FT-IR spectrum (grey) of $4 \mathbf{P d}$ in $\mathrm{CD}_{2} \mathrm{Cl}_{2}$ and fitted line (blue).

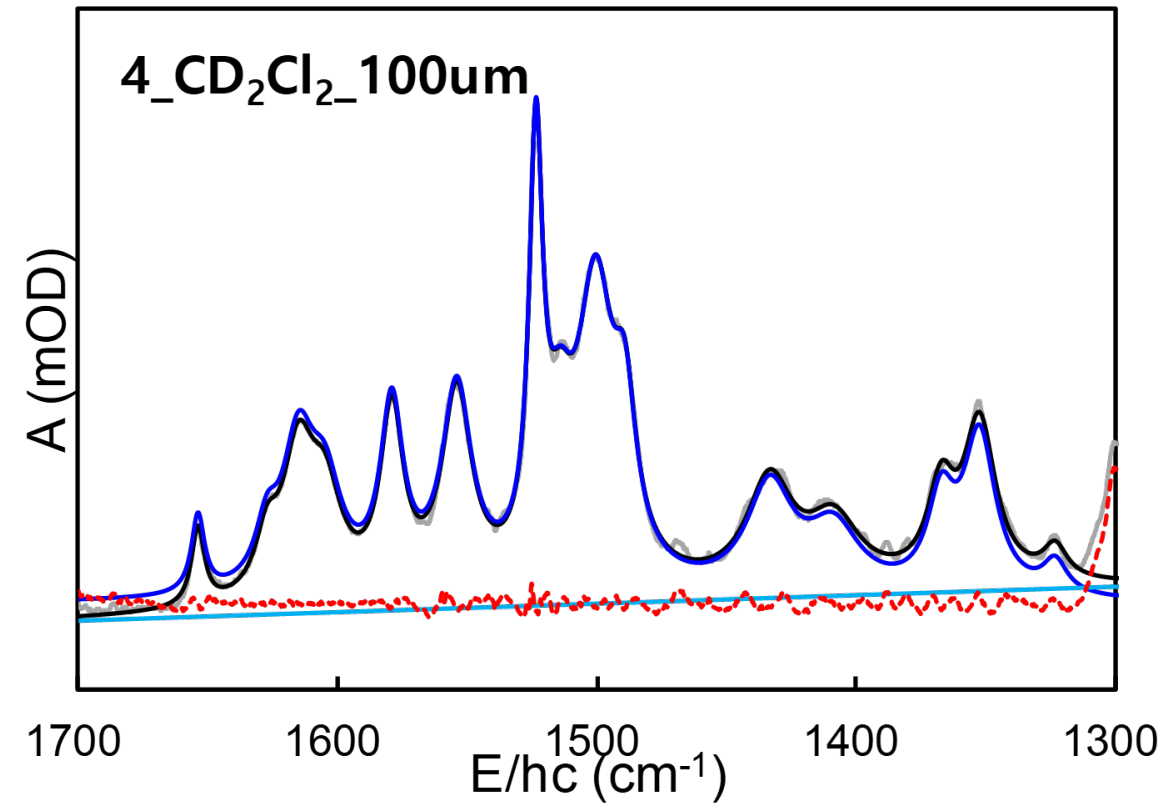

Figure $S$ 8-8. The solution FT-IR spectrum (grey) of 4 in $\mathrm{CD}_{2} \mathrm{Cl}_{2}$ and fitted line (blue). 


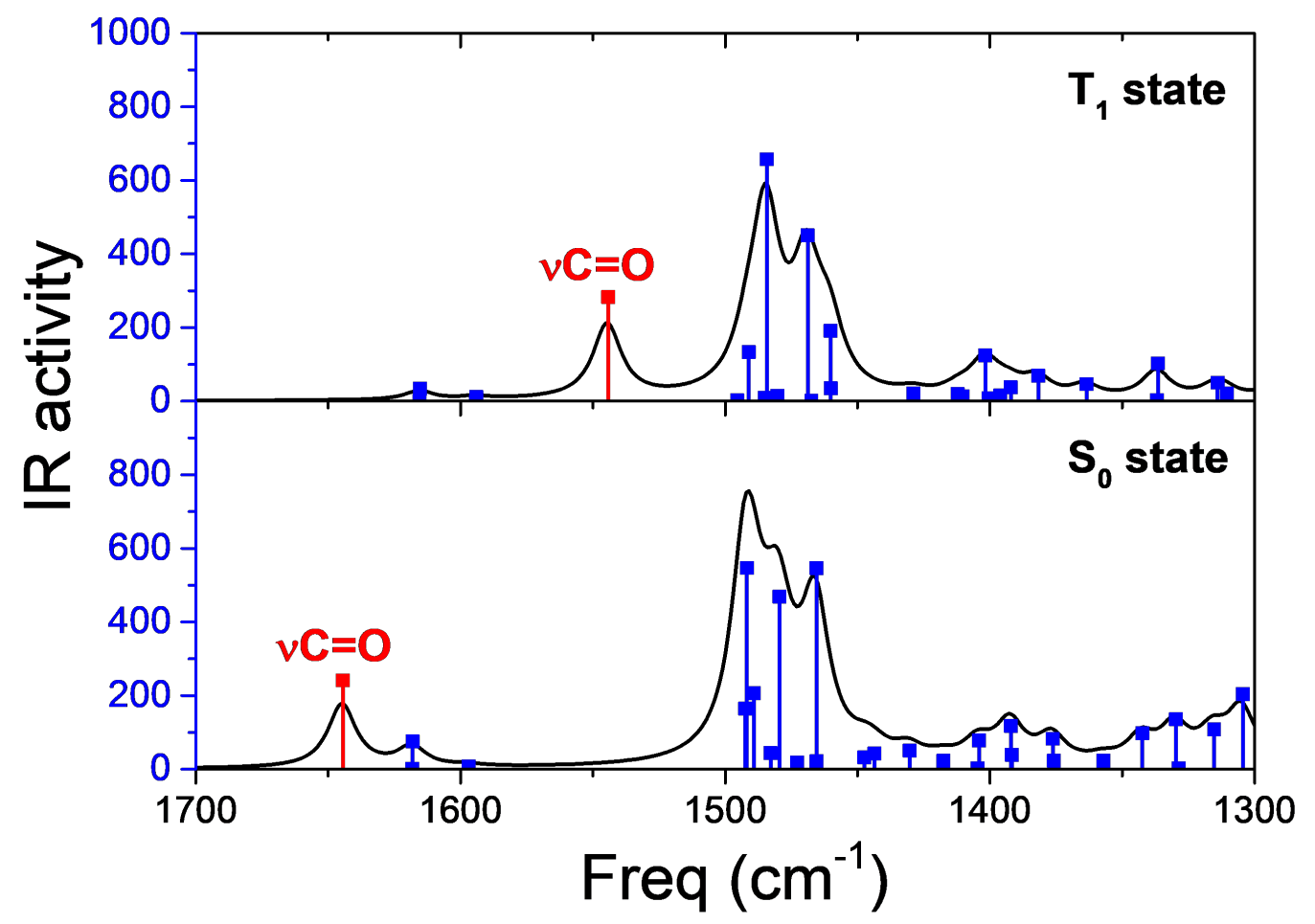

Figure S 8-9. Calculated FT-IR spectra of $4 \mathbf{P d}$ in the $\mathrm{T}_{1}$ (top) and $\mathrm{S}_{0}$ (bottom) state at the level of B3LYP/6-311G(d,p) + SDD (for Pd) (scaling factor: 0.967[s9]). 

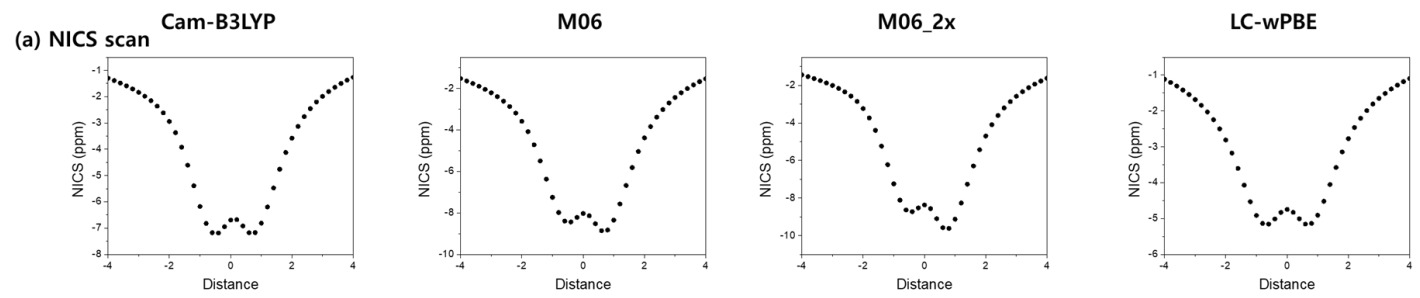

(b) $S_{0}$ Frequency
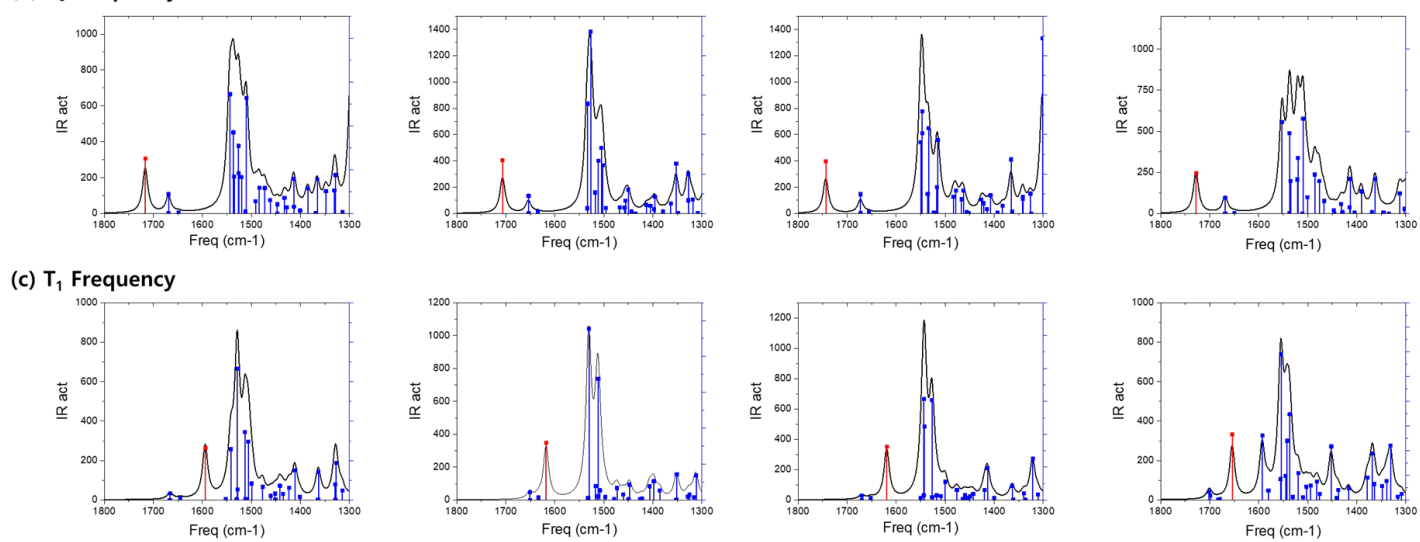

Figure S 8-10. The variations between functionals, (U)CAM-B3LYP, M06, M06-2X, and LC- $\omega$ PBE, with respect to Baird-aromatic characters; (a) NICS, (b) So frequency, and (c) $\mathrm{T}_{1}$ frequency of $\mathbf{4 P d}$. The spectra were not scaled and the shifts of the $\mathrm{C}=\mathrm{O}$ stretching frequencies are marked as the red vibrational modes.

Table S 8-1. Summary of the $\mathrm{C}=\mathrm{O}$ frequency calculated by variable functionals

\begin{tabular}{c|ccccc}
\hline \multicolumn{1}{c}{} & & CAM-B3LYP & M06 & M06-2X & LC- $\omega$ PBE \\
\hline \multirow{2}{*}{$v \mathrm{C}=\mathrm{O}\left(\mathrm{cm}^{-1}\right)$} & $\mathrm{S}_{0}$ & 1715 & 1706 & 1743 & 1727 \\
& & & & & \\
& $\mathrm{~T}_{1}$ & 1593 & 1616 & 1618 & 1619 \\
\hline
\end{tabular}




\section{Excited State Dynamics}

(a)

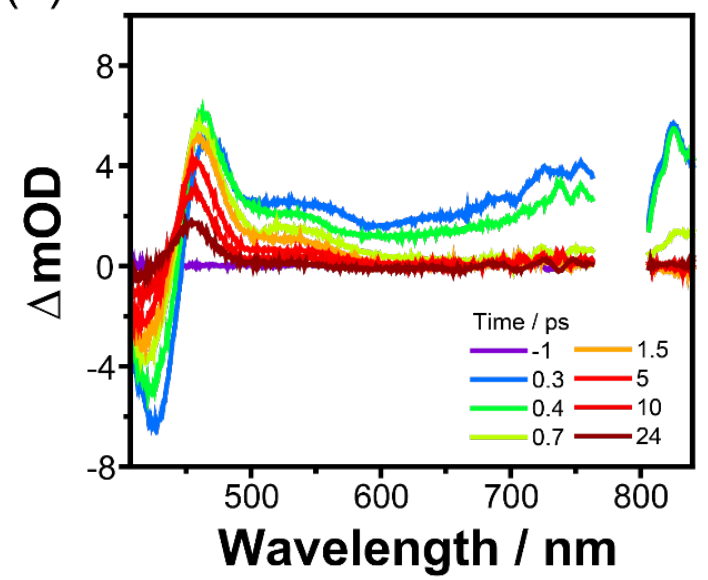

(c)



(b)



(d)

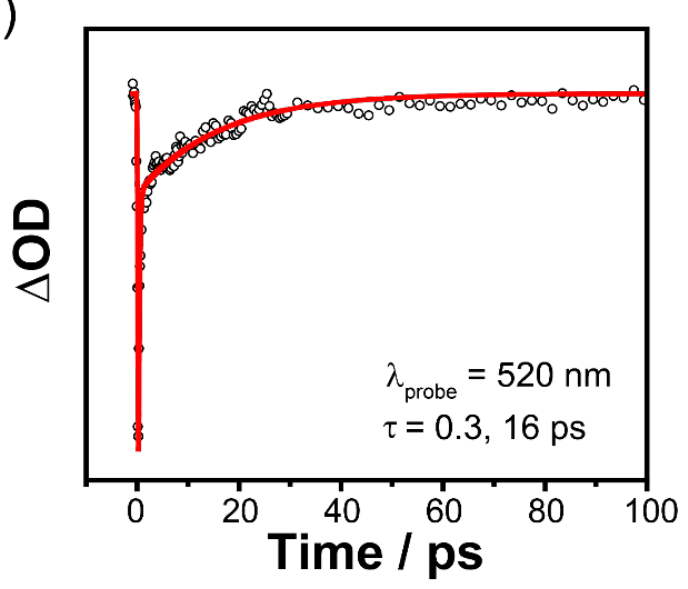

Figure S 9-1. Transient absorption spectra and decay profiles of $(\mathrm{a}, \mathrm{c}) 4$ and $(\mathrm{b}, \mathrm{d})$ $4 \mathrm{ZnPy}$ in $\mathrm{CH}_{2} \mathrm{Cl}_{2}$ upon photoexcitation at $400 \mathrm{~nm}$. 
(a)



(c)

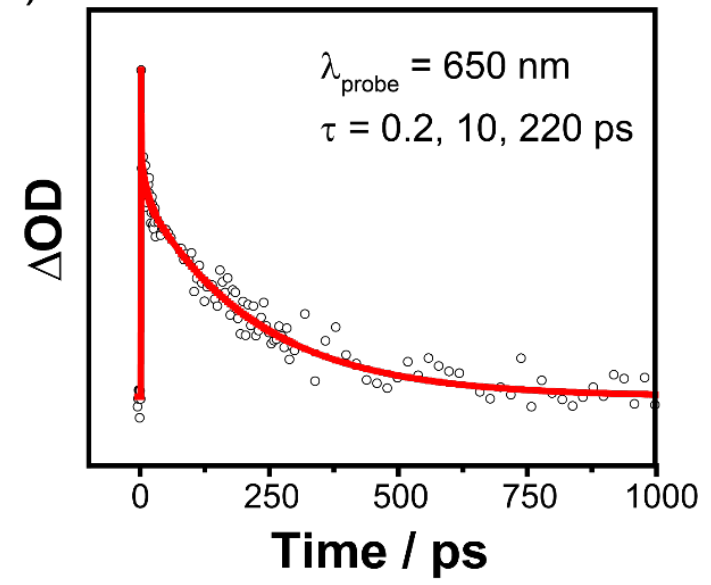

(b)

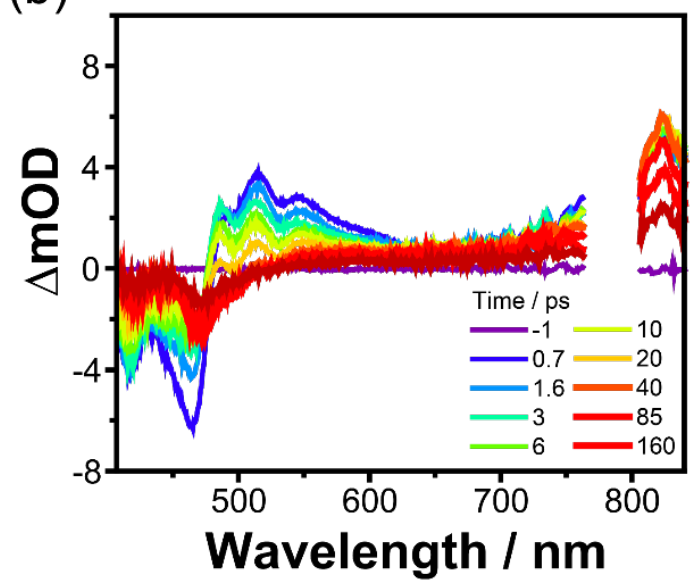

(d)

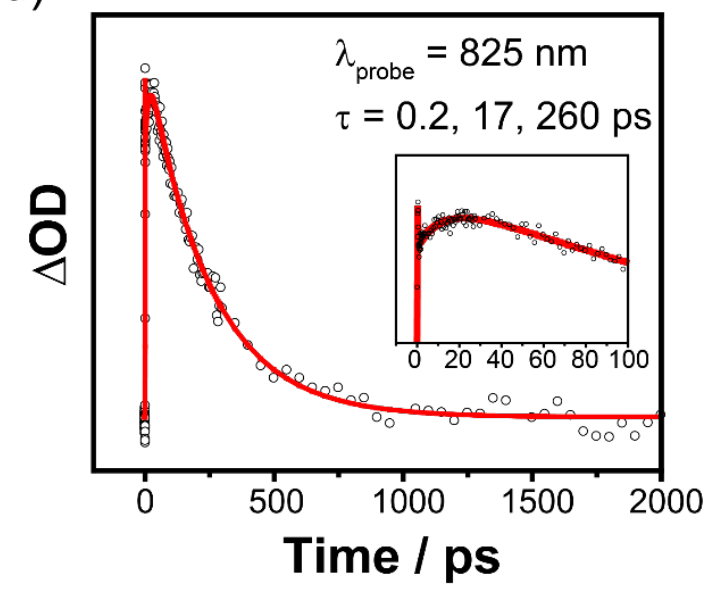

Figure S 9-2. Transient absorption spectra and decay profiles of $(\mathrm{a}, \mathrm{c}) 4 \mathrm{Ni}$ and $(\mathrm{b}, \mathrm{d})$ $4 \mathbf{P d}$ in $\mathrm{CH}_{2} \mathrm{Cl}_{2}$ upon photoexcitation at $400 \mathrm{~nm}$. The inset in (d) shows the decay profile of short time window. 
(a)

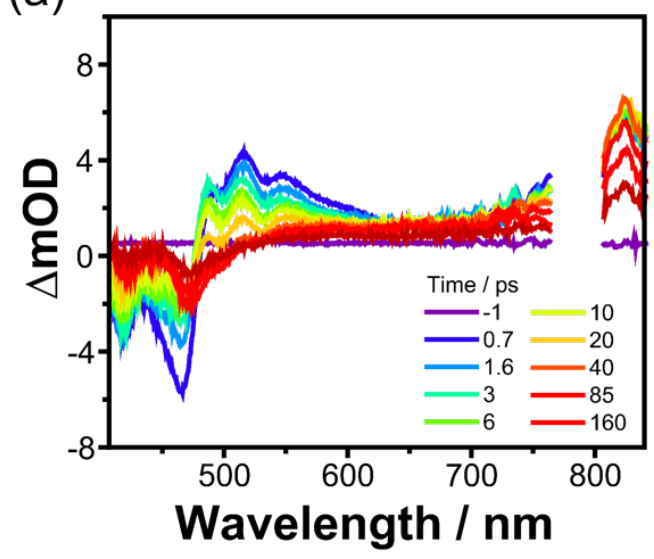

(c)



(b)

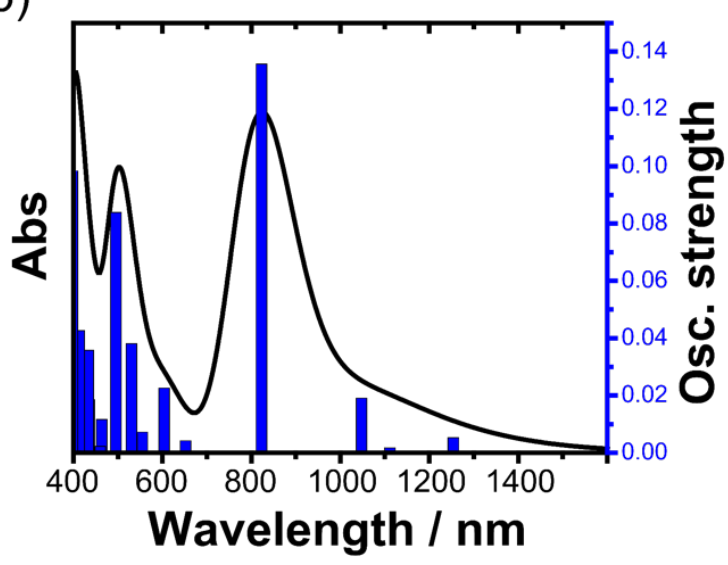

(d)

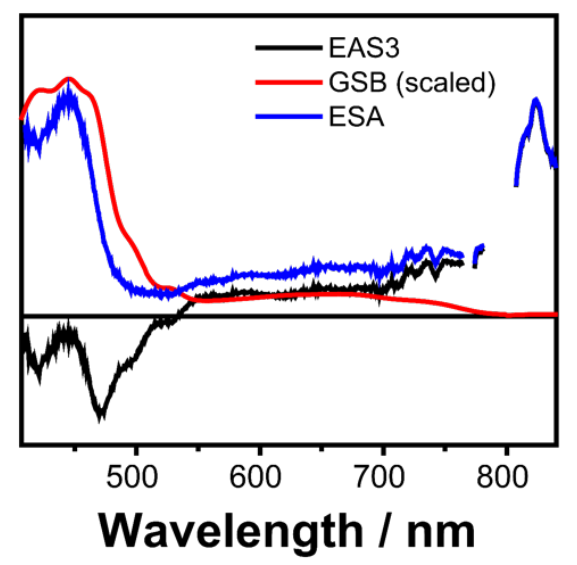

Figure S 9-3. (a) TA spectra of $4 \mathbf{P d}$ and (b) TD-DFT calculation results in the $\mathrm{T}_{1}$ state. (c) The evolution associated spectra of $\mathbf{4 P d}$ and (d) extracted excited state absorption spectrum for the $\mathrm{T}_{1}$ state. 


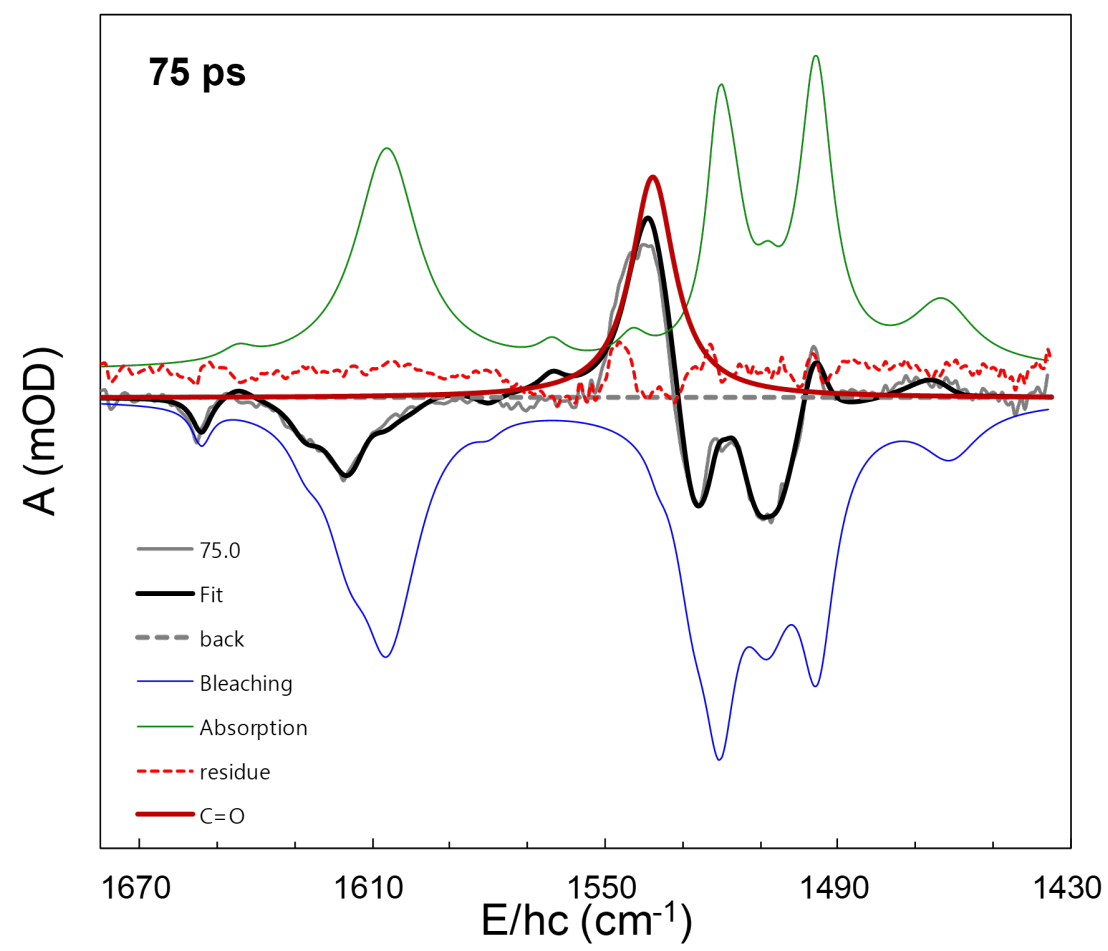

Figure S 9-4. Representative fit (black lines) of the TRIR spectrum at the time delay of 75 ps of $4 \mathbf{P d}$ in $\mathrm{CD}_{2} \mathrm{Cl}_{2}$. Data (grey lines) are well described by the basis spectra (bleaching, absorption, and $\mathrm{C}=\mathrm{O}$ ).

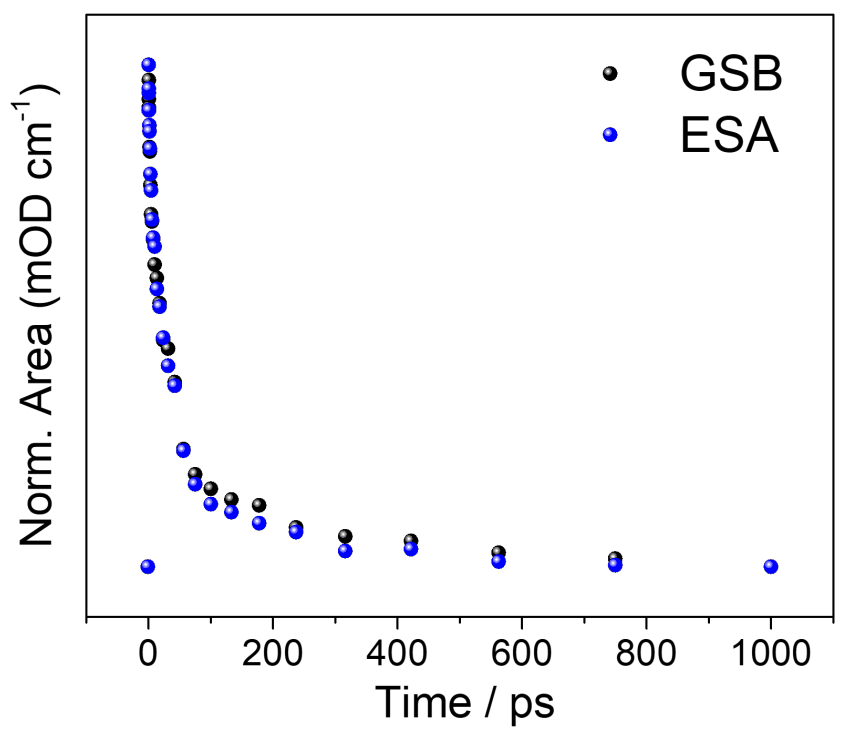

Figure S 9-5. Time-dependent integrated areas of the basis spectra for GSB (FTIR) and ESA. 
(a)



(b)

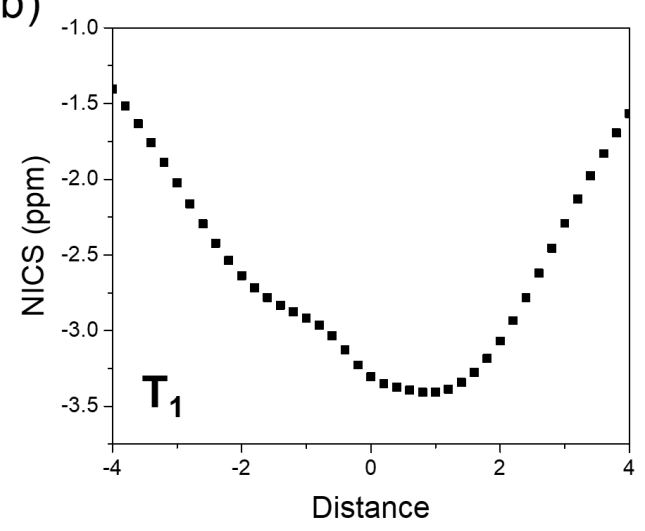

(c)

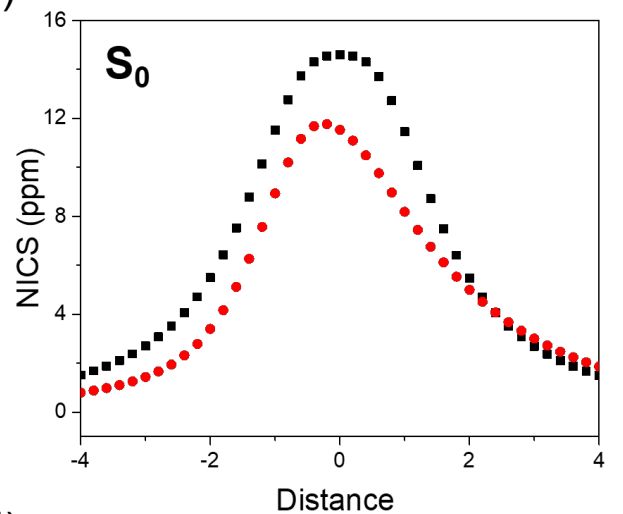

(d)



Figure S 9-6. NICS scan for (a,b) 4 and (c,d) $4 \mathbf{P d}$ in the $S_{0}$ state (top) and $\mathrm{T}_{1}$ state (bottom). Ghost atoms $(\mathrm{Bq})$ were placed equidistantly along the $\mathrm{z}$-axis passing through the center of each ring, at distances to the plane ranging from $-4.0 \AA$ to $4.0 \AA$. The black and red points in $\mathbf{4 P d}$ indicate the different position (E and $\mathrm{F}$ in Figure S7-5). A deep minimum for the out-of-plane component indicates aromaticity in the $\mathrm{T}_{1}$ state. 


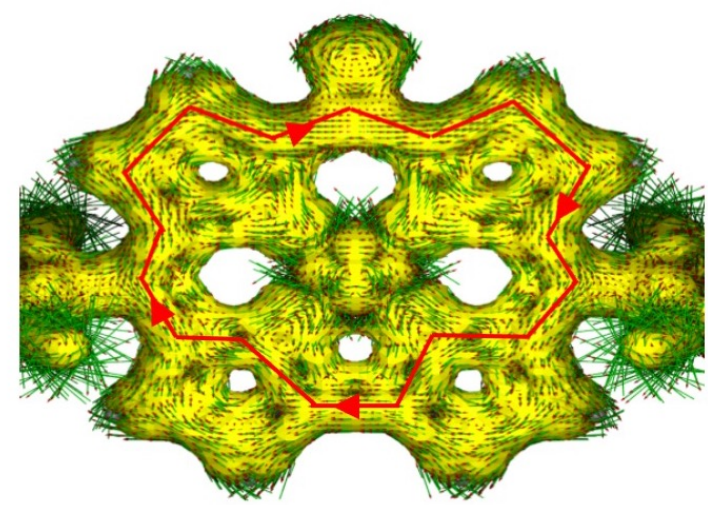

Isovalue $=\mathbf{0} .03$



Isovalue $\mathbf{=} \mathbf{0 . 0 4}$

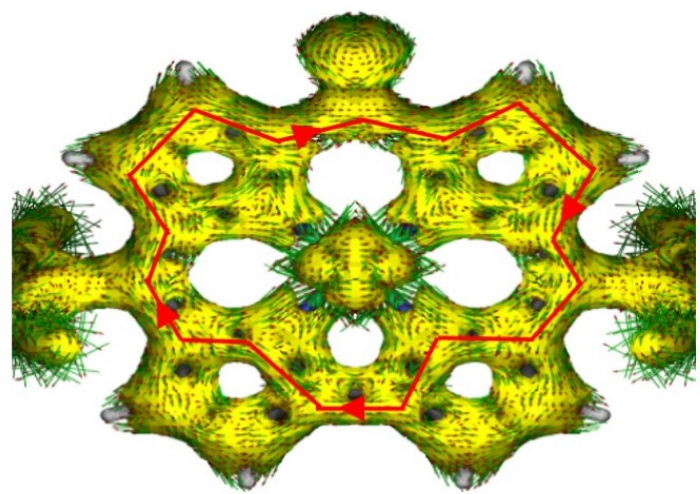

Isovalue $=\mathbf{0} .05$

Figure S 9-7. ACID plots for $\mathbf{4 P d}$ in the $\mathrm{T}_{1}$ state (isovalue $=0.03-0.05$ ) calculated at B3LYP/6-311++G(d,p) level. The clockwise induced ring current flow (red arrows) indicates a diatropic ring current.

*Indeed, the induced current flow through the macrocycle is not strong in the $\mathrm{T}_{1}$-state. Nevertheless, the obvious local ring current in the pyrrole units is not observed and weak current flows exist through the outer macrocycle. As the isovalue decreased, the diatropic ring current features along the outer macrocycle have been strengthened and distinguished from other parts, presumably suggesting the weak Baird aromaticity. 




Figure $S$ 9-8. ACID plot for $4 \mathrm{Ni} \cdot \mathrm{B}\left(\mathrm{C}_{6} \mathrm{~F}_{5}\right)_{3}$ (isovalue $=0.05$ ) in the $\mathrm{T}_{1}$-state calculated at B3LYP/6-311G(d,p) level. The clockwise induced ring current flow (red arrows) indicates a diatropic ring current.



Figure $S$ 9-9. ACID plot for $\mathbf{4 P d}$ (isovalue $=0.05$ ) in the $\mathrm{T}_{1}$-state calculated at B3LYP/6-311G(d,p) level. The clockwise induced ring current flow (red arrows) indicates a diatropic ring current. 


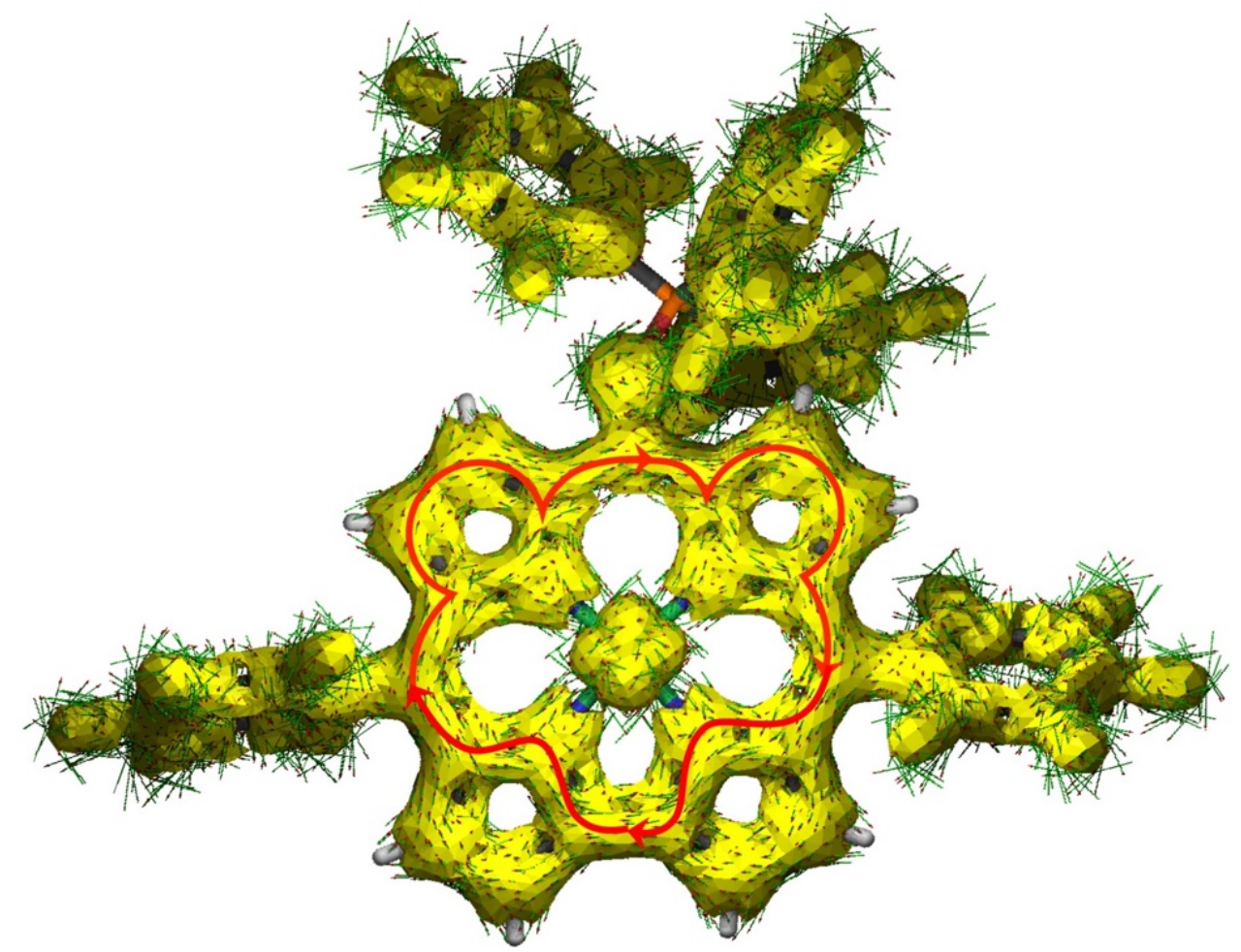

Figure $S$ 9-10. ACID plot for $4 \mathrm{Pd} \cdot \mathrm{B}\left(\mathrm{C}_{6} \mathrm{~F}_{5}\right)_{3}$ (isovalue $=0.05$ ) in the $\mathrm{T}_{1}$-state calculated at B3LYP/6-311G(d,p) level. The clockwise induced ring current flow (red arrows) indicates a diatropic ring current.

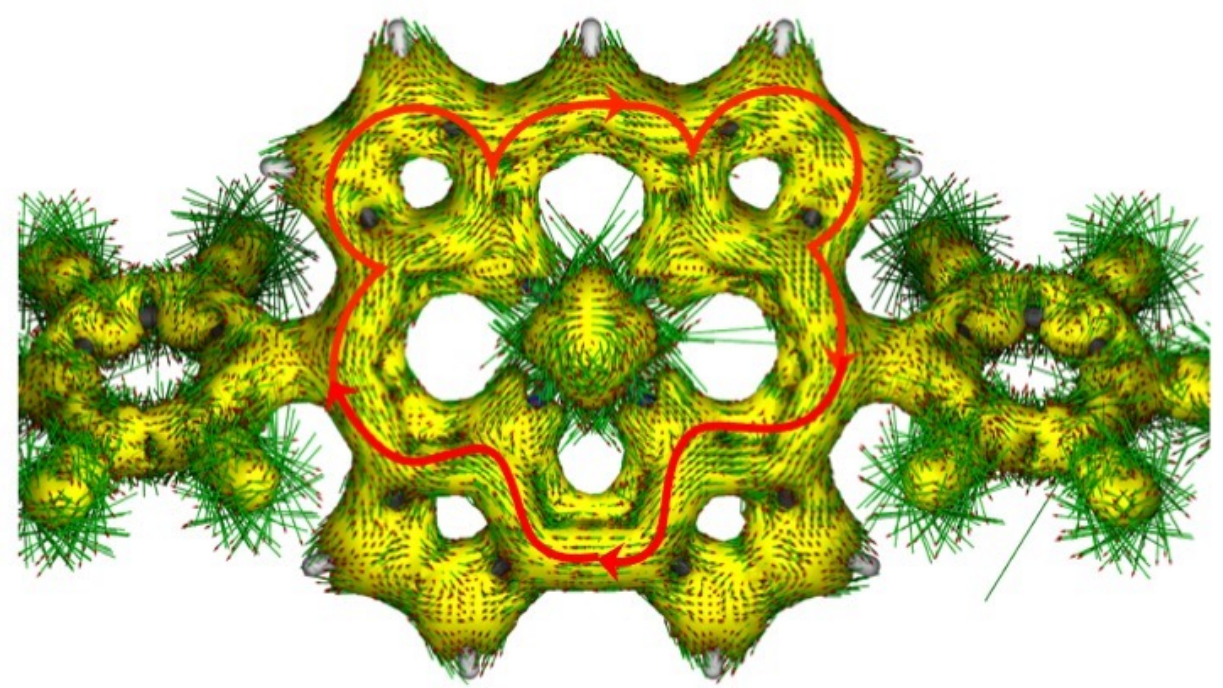

Figure S 9-11. ACID plot for $\mathbf{4} \mathbf{P d H} \mathbf{H}^{+}$(isovalue $=0.05$ ) in the $\mathrm{T}_{1}$-state calculated at B3LYP/6-311G(d,p) level. The clockwise induced ring current flow (red arrows) indicates a diatropic ring current. 


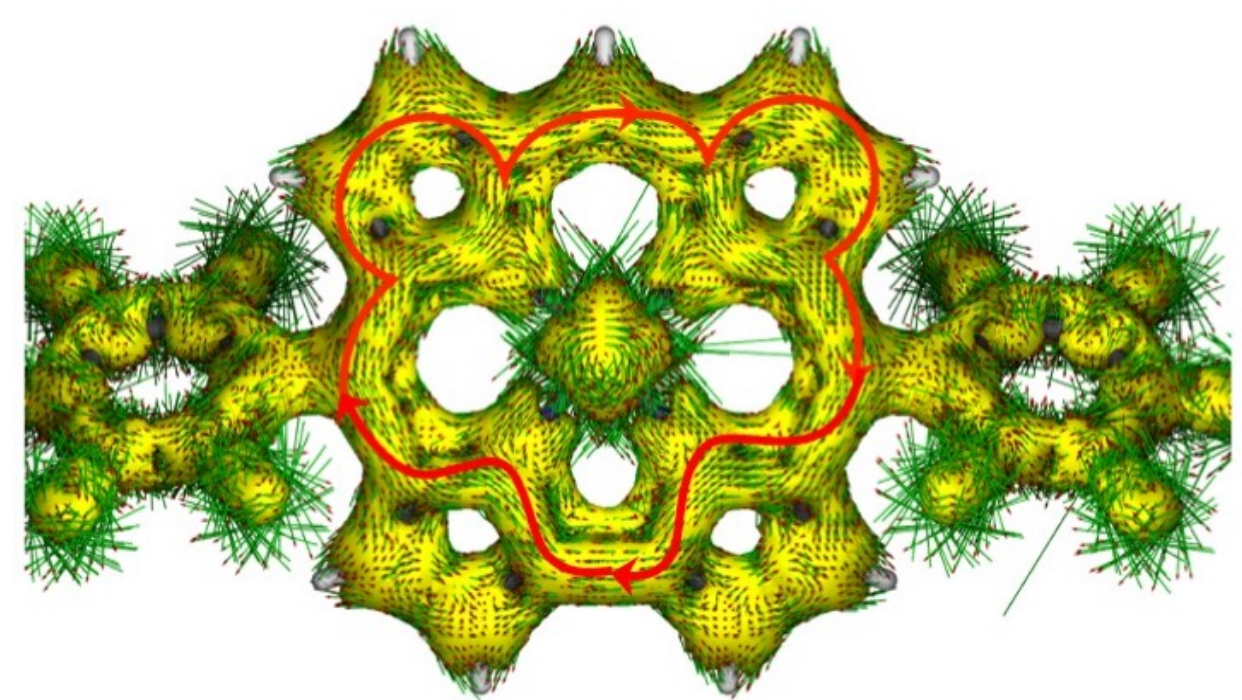

Figure $S$ 9-12. ACID plot for $\mathbf{1} \mathbf{P d}^{+}$(isovalue $=0.05$ ) in the $\mathrm{T}_{1}$-state calculated at B3LYP/6-311G(d,p) level. The clockwise induced ring current flow (red arrows) indicates a diatropic ring current.

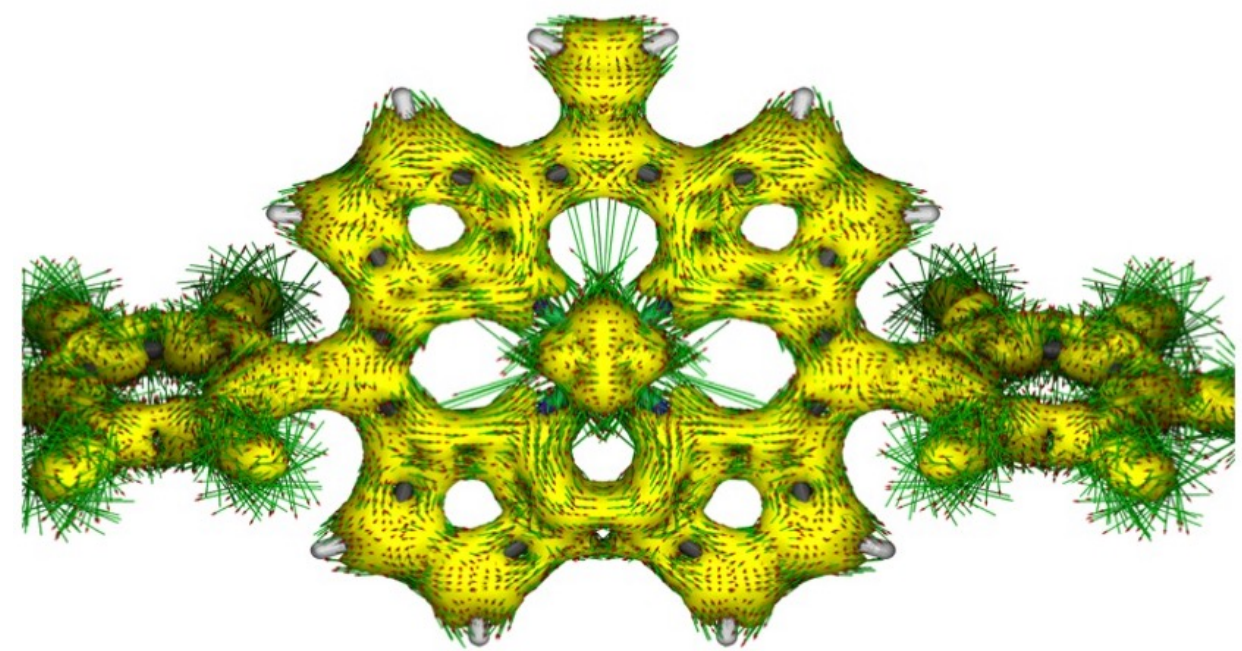

Figure $S$ 9-13. ACID plot for $5 \mathbf{P d}$ (isovalue $=0.05$ ) in the $\mathrm{T}_{1}$-state calculated at B3LYP/6-311G(d,p) level. The clockwise induced ring current flow (red arrows) indicates a diatropic ring current. 


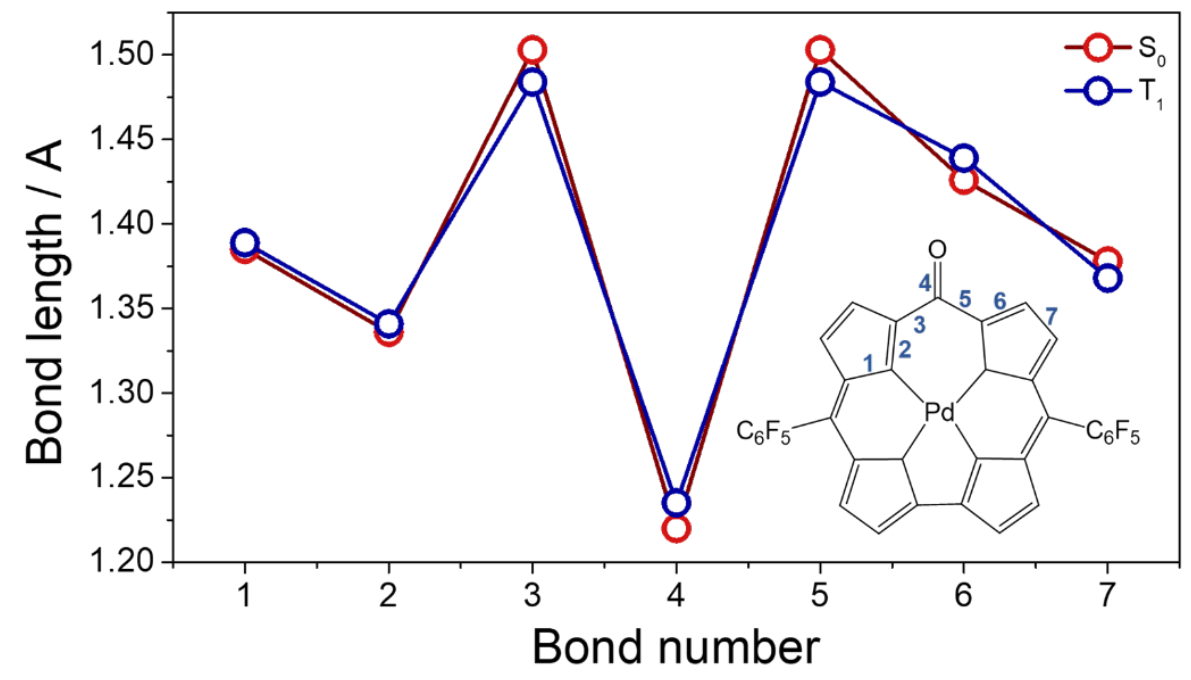

Figure S 9-14. The bond length plot of $4 \mathbf{P d}$ besides the carbonyl group in the $\mathrm{S}_{0}$ and $\mathrm{T}_{1}$ state. 
Table S9-1. Structural analysis on the optimized structures at two different level of theory, B3LYP/6-311G(d,p) and CAM-B3LYP/6-311G(d,p).

\begin{tabular}{|c|c|c|c|c|c|c|c|}
\hline \multirow[t]{2}{*}{ cmpd } & \multirow[t]{2}{*}{ Basis set } & \multicolumn{3}{|c|}{ So-state } & \multicolumn{3}{|c|}{ T1-state } \\
\hline & & $\mathrm{C}=\mathrm{O}[\AA ̊]$ & HOMA & MPD [Å] & $\mathrm{C}=\mathrm{O}[\AA]$ & HOMA & MPD [Å] \\
\hline \multirow[t]{2}{*}{4} & B3LYP & 1.223 & 0.476 & 0.046 & 1.236 & 0.528 & 0.048 \\
\hline & CAM-B3LYP & 1.223 & 0.474 & 0.046 & 1.227 & 0.545 & 0.046 \\
\hline \multirow[t]{2}{*}{$4 \mathrm{Ni}$} & B3LYP & 1.223 & 0.555 & 0.011 & 1.238 & 0.575 & 0.013 \\
\hline & CAM-BЗLYP & 1.214 & 0.598 & 0.010 & 1.230 & 0.599 & 0.012 \\
\hline \multirow[t]{2}{*}{$4 \mathrm{Ni} \cdot \mathrm{B}\left(\mathrm{C}_{6} \mathrm{~F}_{5}\right)_{3}$} & B3LYP & 1.264 & 0.648 & 0.050 & 1.283 & 0.661 & 0.053 \\
\hline & CAM-B3LYP & 1.255 & 0.676 & 0.047 & 1.275 & 0.683 & 0.091 \\
\hline \multirow[t]{2}{*}{ 4ZnPy } & B3LYP & 1.222 & 0.295 & 0.130 & 1.236 & 0.361 & 0.166 \\
\hline & CAM-B3LYP & 1.214 & 0.344 & 0.124 & 1.228 & 0.414 & 0.162 \\
\hline \multirow[t]{2}{*}{$4 \mathrm{Pd}$} & B3LYP & 1.220 & 0.294 & 0.014 & 1.235 & 0.362 & 0.016 \\
\hline & CAM-B3LYP & 1.211 & 0.381 & 0.012 & 1.227 & 0.416 & 0.015 \\
\hline \multirow[t]{2}{*}{$4 \mathrm{Pd} \cdot \mathrm{B}\left(\mathrm{C}_{6} \mathrm{~F}_{5}\right)_{3}$} & B3LYP & 1.261 & 0.422 & 0.045 & 1.281 & 0.485 & 0.050 \\
\hline & CAM-B3LYP & 1.252 & 0.480 & 0.048 & 1.274 & 0.533 & 0.049 \\
\hline \multirow[t]{2}{*}{$4 \mathrm{PdH}^{+}$} & B3LYP & 1.325 & 0.425 & 0.034 & 1.340 & 0.551 & 0.025 \\
\hline & CAM-B3LYP & 1.315 & 0.444 & 0.027 & 1.331 & 0.611 & 0.021 \\
\hline \multirow[t]{2}{*}{$1 \mathbf{P d}^{+}$} & B3LYP & - & 0.381 & 0.037 & - & 0.550 & 0.028 \\
\hline & CAM-B3LYP & - & 0.381 & 0.030 & - & 0.614 & 0.022 \\
\hline \multirow[t]{2}{*}{$5 P d$} & B3LYP & - & 0.429 & 0.011 & - & 0.442 & 0.016 \\
\hline & CAM-B3LYP & - & 0.475 & 0.010 & - & 0.482 & 0.015 \\
\hline
\end{tabular}




\section{Supporting References}

[S1] Sheldrick, G. M. SHELXT - Integrated space-group and crystal-structure determination. Acta Cryst. 2015, A71, 3-8.

[S2] Sheldrick, G. M.; Schneider, T. R. SHELXL: High-resolution refinement. Methods Enzymol. $1997,277,319-343$.

[S3] Sheldrick, G. M. Crystal structure refinement with SHELXL. Acta Cryst. 2015, C71, 3-8.

[S4] Gaussian 16, Revision B.01, Frisch, M. J.; Trucks, G. W.; Schlegel, H. B.; Scuseria, G. E.; Robb, M. A.; Cheeseman, J. R.; Scalmani, G.; Barone, V.; Petersson, G. A.; Nakatsuji, H.; Li, X.; Caricato, M.; Marenich, A. V.; Bloino, J.; Janesko, B. G.; Gomperts, R.; Mennucci, B.; Hratchian, H. P.; Ortiz, J. V.; Izmaylov, A. F.; Sonnenberg, J. L.; Williams-Young, D.; Ding, F.; Lipparini, F.; Egidi, F.; Goings, J.; Peng, B.; Petrone, A.; Henderson, T.; Ranasinghe, D.; Zakrzewski, V. G.; Gao, J.; Rega, N.; Zheng, G.; Liang, W.; Hada, M.; Ehara, M.; Toyota, K.; Fukuda, R.; Hasegawa, J.; Ishida, M.; Nakajima, T.; Honda, Y.; Kitao, O.; Nakai, H.; Vreven, T.; Throssell, K.; Montgomery, J. A., Jr.; Peralta, J. E.; Ogliaro, F.; Bearpark, M. J.; Heyd, J. J.; Brothers, E. N.; Kudin, K. N.; Staroverov, V. N.; Keith, T. A.; Kobayashi, R.; Normand, J.; Raghavachari, K.; Rendell, A. P.; Burant, J. C.; Iyengar, S. S.; Tomasi, J.; Cossi, M.; Millam, J. M.; Klene, M.; Adamo, C.; Cammi, R.; Ochterski, J. W.; Martin, R. L.; Morokuma, K.; Farkas, O.; Foresman, J. B.; Fox, D. J. Gaussian, Inc., Wallingford CT, 2016.

[S5] Sung, Y. M.; Yoon, M. C.; Lim, J. M.; Rath, H.; Naoda, K.; Osuka, A.; Kim, D. Reversal of Hückel (anti)aromaticity in the lowest triplet states of hexaphyrins and spectroscopic evidence for Baird's rule. Nat. Chem. 2015, 7, 418-422.

[S6] Kim, S.; Lim, M. Protein Conformation-Induced Modulation of Ligand Binding Kinetics: A Femtosecond Mid-IR Study of Nitric Oxide Binding Trajectories in Myoglobin. J. Am. Chem. Soc. 2005, 127, 8908-8909.

[S7] Kim, S.; Park, J.; Lee, T.; Lim, M. Direct Observation of Ligand Rebinding Pathways in Hemoglobin Using Femtosecond Mid-IR Spectroscopy. J. Phys. Chem. B 2012, 116, 6346-6355. [S8] Ooi, S.; Yoneda, T.; Tanaka, T.; Osuka, A. meso-Free Corroles: Syntheses, Structures, Properties, and Chemical Reactivities. Chem. Eur. J. 2015, 21, 7772-7779.

[S9] The NIST standard reference "https://cccbdb.nist.gov/vibscalejust.asp" 